Journal of the Scientific Agricultural Society of Finland Vol. 50: 1-66, 1978

Maataloustieteellinen aikakausikirja

\title{
ACCURACY OF TIMING IN SOME TIME STUDY METHODS
}

Selostus: Ajanmittauksen tarkkuudesta aikatutkimuksessa

\author{
A A R N PEH K O E N \\ Department of Agricultural Engineering, University of Helsinki \\ Viikki, SF-00710 Helsinki 71, Finland
}

TO BE PRESENTED, WITH THE PREMISSION OF THE Faculty of Agriculture and Forestry of the UNIVERSITY OF HeLSINKI, FOR PUBLIC CRITICISM in auditorium Porthania iII, on May 20, 1978 AT 10 o'CLOCK. 
ISBN 951-9041-06-C

ISSN 0024-8835 


\section{Preface}

Now that my study has been completed it is my pleasure to thank all those who have given me their assistance. As this particular study is part of a project implemented by the Department of Agricultural Engineering, University of Helsinki, I am happy to express my gratitude to the Department and especially to its former Head and my teacher, Assistant Professor Erkki H. Oksanen, for their positive attitude throughout the work. The manuscript was also read by professors Kalle Putkisto and K. J. Weckman who gave valuable advice especially in planning the general background part of the study.

Mr Pekka Suomalainen carried out the electronic planning and building of the work study simulator that played a keyrole in the study. I am indebted to the teachers at Rastor and Tietomies courses for helping me to organize the tests. Mr Jorma Hotanen in particular deserves my special thanks. The ready cooperation of the test persons greatly facilitated my task.

The processing of the vast data material would have been practically impossible without the assistance of the Computing Centre of Helsinki University, whose computers and programmes were also used to process the data. The study was translated into English by Mrs Liisa Ritarsalo, M. A. with the aid of Mrs Leena Danson. To them and all others who helped me during this study I would like to extend my sincere thanks.

Without the grants received from the Scientific Foundation of Finnish Agricultural Graduates, the August-Johannes and Aino Tiura Agricultural Research Foundation and the Finnish Foundation Cultural this thesis could not have been completed. Finally, I am grateful to the Scientific Agricultural Society of Finland for including this study in its series.

Helsinki, April 1978

Aarne Pehkonen 



\section{CONTENTS}

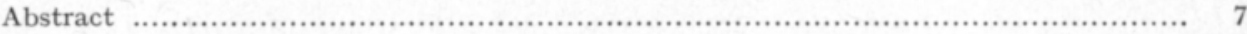

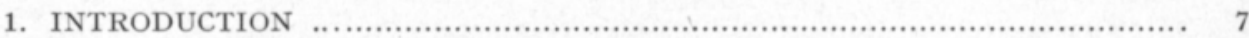

11. A survey of work measurement techniques ........................................ 8

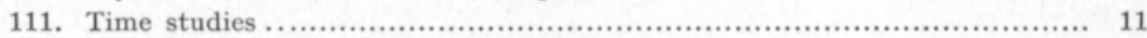

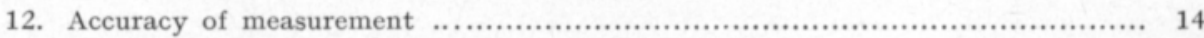

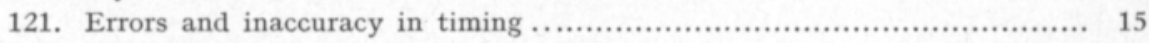

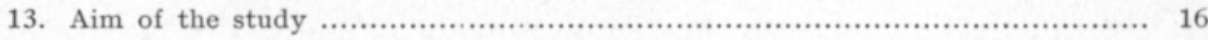

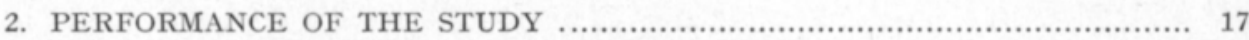

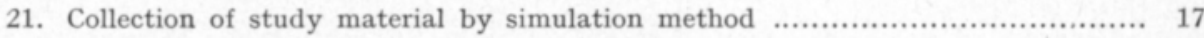

211. On the analogy between simulation and normal work as study object ...... 19

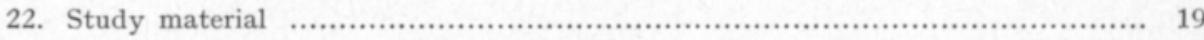

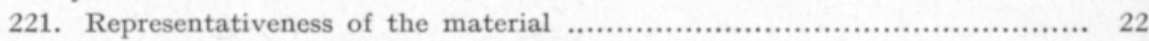

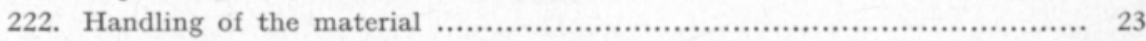

23. On the criteria of the measuring accuracy ............................................ 24

3. MEASURING ACCURACY AND FACTORS AFFECTING IT REVIEWED IN THE

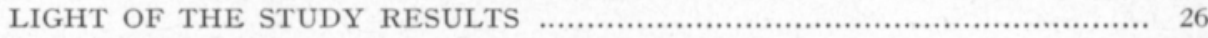

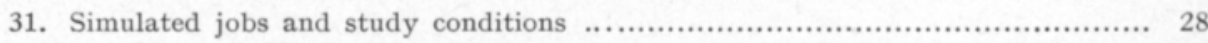

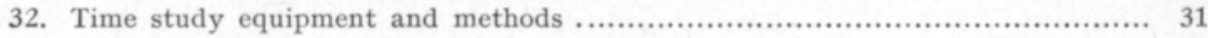

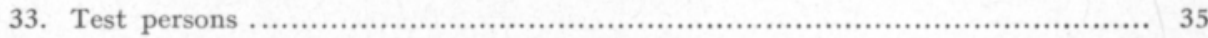

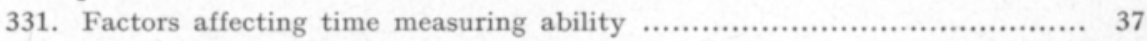

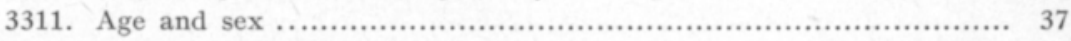

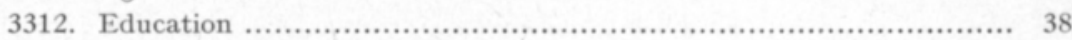

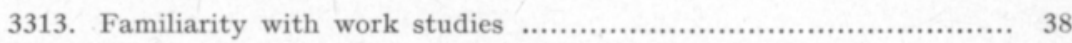

3314. Intelligence and techno-mechanical talent ............................ 39

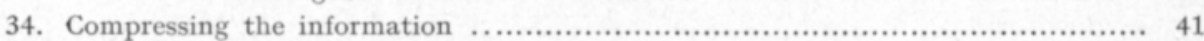

35. The explaining models for measuring accuracy ...................................... 46

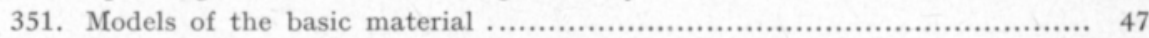

352. Models in the human factors material ........................................ 51

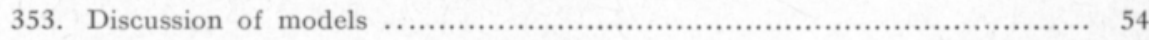

36. Discussion and conclusions ......................................................... 55

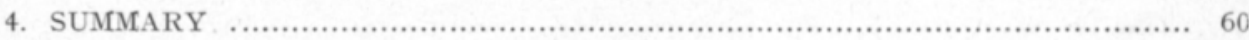

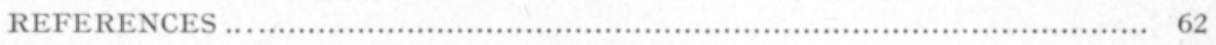

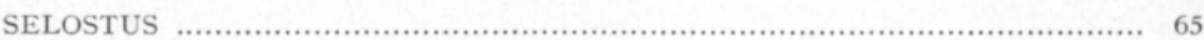




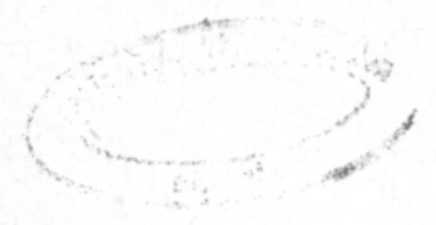




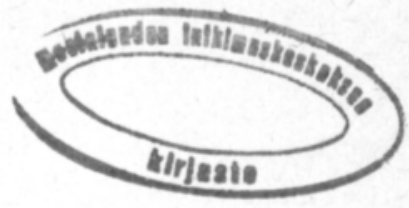

\begin{abstract}
With measured times varying between $3 \ldots 115 \mathrm{cmin}$ (average $19 \mathrm{cmin}$ ) the average deviation in the use of time study instruments (approximately 63000 times) was $0,83 \mathrm{cmin}(6,4 \%)$. As the times became shorter, below $15 \ldots 20 \mathrm{cmin}$, there was a sharp decline in the relative measuring accuracy. The measuring accuracy improved when conditions at the study location were favourable to the observation of the break point or limited the reception of information other than that coming from the study object. The measuring accuracy of watches with pointer display improved if the pointer could be stopped at the moment of measuring and the result read out afterwards. The variables describing the characteristics of the test person, e.g. age, basic schooling, degree of training and intelligence, were correlated with the measuring accuracy. The measuring of times did not seem to require special techno-mechanical talent. With the aid of variables that describe the characteristics of the test persons and that can be determined in a simple manner it is not possible to give a reliable estimate as to how well a specific person is suited to the task of a time investigator. This problem may be solved by using, for example, a work test based on simulation.
\end{abstract}

\title{
1. Introduction
}

In agriculture, jobs connected with a biological production entity generally have a certain optimal period when the best qualitative and/or quantitative output can be obtained. There are, however, a number of jobs that can be carried out only under specific external conditions. These two separate factors mean that the time available for carrying out several agricultural jobs is restricted to a relatively short period.

To enable the jobs to be completed within the period defined by the factors stated above, sufficient man power, machines and other technical implements are required. With the present high level of machine and labour costs it is essential to determine the real requirements and to have available only what is economically essential. For this purpose reliable data should be available, for example, the times required by different jobs, in other words, time norms in some form.

To facilitate planning, standard time systems and other collections of norms have been compiled in several fields including agriculture (e.g. LIEM and GERRITSen 1968, Anon. 1971 a, Anon. 1972 b, Aulanko et al. 1973, Menneer 1976). This has increased the necessity for the time values on which the collections of norms are based, and has placed on them new requirements, in particular as regards accuracy and general applicability. It also stresses how 
imperative is the need for developing the methods used in determining the actual time values.

Time values of different jobs and their elements are essential not only in planning but also generally in rationalization, e.g. in method studies in which various alternatives are compared, in defining wage principles, and in cost estimates (e.g. Putkisto 1956, p. 63, Nightingale 1972, Olkkonen and Aulanko 1972).

According to Aulanko (1973), different usage requirements place different demands on the time values. In certain instances the main point of interest is the absolute time of the job or its elements, in others it is the relation between the times (e.g. Kärkkärnen 1971, Anon. 1971 a, Olkkonen and Aulanko 1972). Thus it is not possible to make any general detailed demands of the figures that depict consumption of time; the accuracy required of the figures used as the basis of time norms depends largely on job breakdown and the value of each separate element. To select a suitably accurate method for measurement, it should be known for what purpose the results will be used and what the accuracy requirements are at the actual time of measuring.

The accuracy required by time values under different conditions as well as the accuracy of measurement and the factors affecting it constitute an extensive and complex question. It is practically impossible to solve it within the limits of a single study, and so the focus will be on accuracy of timing (see p. 16). Other questions have been discussed simply as a general background to the whole question.

\section{A survey of work measurement techniques}

The norm values or corresponding figures projecting working time consumption are generally obtained from and based on the results of work measurement. According to Barnes (1968, p. 5), Finnish Dictionary of Rationalization (Anon. $1971 \mathrm{~b}$ ) and ILO (ANON. 1974 a, p. 211), work measurement is the application of methods and techniques designed to establish the time for a qualified and well trained worker to carry out a specified job with a specific method at normal level of performance under specific conditions. The outcome of the work measurement is the unit work or the standard time.

Time can be measured or defined by various methods, e.g. time study, activity sampling and predetermined motion time study. In agriculture the method most commonly used is time study. Figure 1 shows how the results of work measurement, unit work or standard time are formed by these methods according to the practice adopted in work studies carried out by Finnish industry (ANON. 1971 b, Hotanen 1977)

Average production figures drawn from large scale production statistics are used for instance in agriculture and forestry to portray working time consumption in the same way as are time values determined by normal work measurement. These figures show neither the different times needed for each subtask nor the factors affecting labour output (productivity). Therefore these results are of more limited use than are those of normal work measure-

- ment. The information gained from these figures is of little value to method 


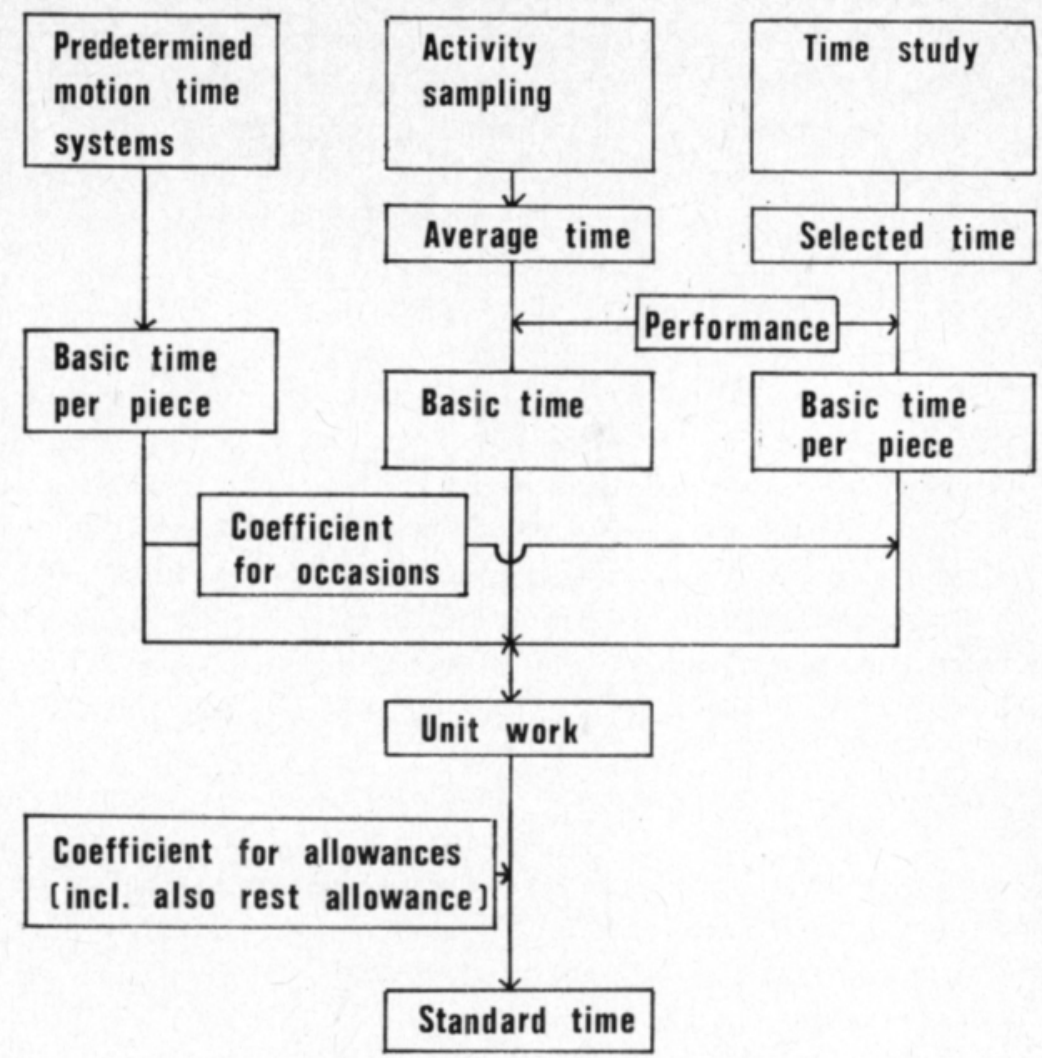

Figure. 1. Unit work and standard time composed by some work measurement techniques.

study for instance. The duration of normal machine-controlled times can be determined by calculation without a time study proper. In some cases time values are also determined by rating. The accuracy of these results, however, tends to be poor (Vöry 1954, KärkKärnen 1971, Anon. 1971 a, OlkkoneN and Aulanko 1972, Hotanen 1977).

In industry the main objective of time study was originally to determine the so-called basic time (e.g. Alfthan 1943). This objective remains the same today, although, according to Aulanko (1973), the methods used in work measurement have become more versatile. Similarly the rather definite limits that used to restrict the adaptability of different work study methods for use in the two traditional fields, method study and work measurement, have become more flexible. Techniques such as predetermined motion time systems are used for both purposes (Putkisto 1956, p. 65, Barnes 1968, p. 417, Aulanko et al. 1973, Menneer 1976).

When a job is measured on different occasions the resulting time values may differ. This is not necessarily because of real errors, but because of variations e.g. in working speed, method and work conditions affecting labour output (Hilf 1957, p. 229, Pukkila 1959, p. 217, Barnes 1968, p. 339, Olkkonen and Aulanko 1972). 
A crucial problem in work measurement performed as time study and activity sampling is the elimination of variation in working speed (compare Fig. 1). In studies directed at unit work the measuring results must be normalized to correspond to normal working speed, that is the-so-called standard performance. The use of the so-called performance coefficient for this purpose has spread widely especially in industrial work studies (PUKKILA 1959, p. 220, Barnes 1968, p. 374, Anon. 1974 a, p. 253).

There is, however, no practical method for measuring performance, and in practice it is done by rating. This defining method based on estimation can be and has been criticized with good reason. But, on the other hand, when a working method and conditions can be defined in enough detail and when they remain constant, the use of a performance coefficient (rating factor) eliminates the variations in the results caused by the different working speeds of the workers. As a result of systematic and continuous practice it is proved to be possible in rating performance to obtain accurate enough ratings (ForNaLlaz 1948, 1950, 1952, Hilf 1957, p. 223, Pietola 1971, Baker 1976, Hotanen 1976, SteELE 1977).

A general tendency towards time standards has been adopted also in studies on agricultural jobs. The methods used to define these standards, especially the use of performance in normalizing, are not as established as are work studies used within industry. The methods vary depending on the country and circumstances in which they are used (SipILÄ 1946, p. 60, Anon. 1962, p. 23, Liem and Gerritsen 1968, Bosch et al. 1975).

In Scandinavia little use is made of performance (Haraldson 1956). In Finland for instance, the so-called time standards for agricultural jobs are based on means, which do not take performance into consideration (ANon. 1971 a). In some cases, however, the use of performance has been found essential (OKSANEN et al. 1973). In Germany, where the influence of the REFA-system is considerable, performance ratings are widely used in agricultural jobs (Schweitzer 1963, Hammerschmidt 1964). Although regarded as necessary, rating of performance is still considered difficult in practice (Hammer and Heiland 1967, Hammer 1975, p. 39).

The situation is similar in forest work science. In Scandinavia the general attitude towards performance rating is negative and it is employed only in special cases. Earlier in Central Europe the tendency was to use normalization in forest work in the same way as in industry. Now, however, in forestry a critical attitude towards the use of performance has become more common (HILF 1957, p. 233, KÄRKKÄINEN 1971, HARSTELA 1975).

In Germany performance rating is used widely in work studies of domestic work (KEHR 1968, StÜBler 1972). In Finland some studies have been published where performance has been employed in the same way as in industrial work study (Oittila 1975, Anon. 1972 b).

Another difficulty connected with normalizing the results of work measurement is how to eliminate the difference in strain of various jobs. In the industrial work study norms in Finland these differences are taken into consideration (Fig. 1, p. 9) as a relaxation time included in the time for allowances. In principle similar methods for determining relaxation allowance are common in 
industrial work studies, although calculation methods vary (e.g. Fig. 2, p. 13). The relaxation allowance is determined in practice with the aid of tables based on physiological research data (BArnes 1968, p. 397, Anon. 1973, p. 305, Anon. 1974 a, p. 293, Anon. 1975).

In work studies in the fields of agriculture, forestry and domestic work the use of the relaxation allowance has a very unstable position. It has been used in some studies, but differences in strain are often taken into consideration by using, for instance, the means of labour output (HAMmerschmidT 1964, KäRKKärnen 1971, Anon. 1971 a, Anon. 1972 b).

The detailed work which has gone into the work specification and labour output has a decisive effect on the accuracy of the time standards achieved by time study and activity sampling. If the description of the working methods and conditions is not detailed enough, the method and conditions may vary considerably within the limits of the work specification. These variations affect time values and thus also the entire accuracy of work measurement. This is a serious problem also in agricultural jobs. In work measurement performed by predetermined motion time systems the working method is described in great detail. In these techniques the work measurement is in fact based on the detailed work specification, and time values are calculated in each method according to detailed time standards (e.g. Barnes 1968, p. 471, Liem and Gerritsen 1968, Bosch et al. 1975).

Later in this study the main emphasis will be placed on examining work measurement performed by time study. Activity sampling and predetermined motion time systems have not been included although both are also used in agricultural work studies (Liem and Gerritsen 1968, OKSANEN 1968, Wilking 1969, Bosch et al. 1975, Menneer 1976). As stated earlier, in predetermined motion time systems time values are obtained as a by-product of the work specification. Thus these methods are not concerned with a primary time measurement technique. Activity sampling is mainly employed to clarify the relationship between the times of various work stages. With these relative time values it is in fact possible to determine mean absolute time values. Detailed formulas have been derived for various applications of the activity sampling. The accuracy of the results can be calculated on the basis of these formulas (e.g. Mevert 1963, Hovi et al. 1967).

\section{Time studies}

In the literature time study is defined as a method for determining the amount of time that a well-trained person will need to perform a job by a specified method under certain conditions if he works at a normal tempo (e.g. BARnes 1968 , p. 342, Mundel 1970 , p. 287). The definition of time study and work measurement correspond to each other which is as it should be, since time study is one method of work measurement.

A time study for obtaining unit work is generally a sample of work (e.g. BÄCKLIN et al. 1965). In this case it is essential for the practicability of the result that the sample is representative, a point that is stressed with good reason among others by ÅBERG (1968), FeIn (1973) and TABERnacle (1975). In the development of new working methods or in work studies performed by 
similar purpose the main point is not the actual sampling and its representativeness but the comparison in general of various alternatives in given circumstances.

In work measurement done by time study the various elements of the job are measured by time measurement equipment that includes several different types and models and can be roughly divided into two main groups:

1. Read out type time measurement equipment in which measuring result has to be read from its display device and recorded manually.

2. Registering time measurement equipment in which each measuring result is recorded without manual work either directly to the measurement equipment or on a separate unit.

For the present the time study technique using watch methods which is part of the first group is clearly the most widely spread. Although watch methods have some generally known faults (PukKILA 1948, Nisula 1963, HeInz 1967, NoRd 1968), they are likely to retain their popularity in the near future, owing to the simplicity and low cost of the equipment. Much time study equipment has been developed to replace work study watches (e.g. Krause 1962, 1972, Lorenz 1966, HöBel 1970), but they are still limited in usefulness.

Time studies comprise several stages that can be divided into three main groups as shown in Figure 2 (KRAUSE and WASmund 1962, Krause 1964, Olkkonen and Aulanko 1972, Svensson and Tiberg 1972, Baker 1976):

- Preparatory phase

- Timing phase

- Interpretation and calculation phase

All three phases affect the accuracy of the work measurement results obtained by the time study, the basic time or the unit work. We must agree with KRAUSE and WASMUND (1962) that the timing phase should be considerad the most decisive; it is generally the only real measurement phase in a time study. The importance of timing is stressed even further in studies comparing the output of machine work. In these, selected time can usually be used as the criteria of comparison (see Fig. 1, p. 9), and thus the results are free from the difficulties of determining performance and relaxation allowance. In these studies, as well as in all other work measurements, it is essential to measure the work output and determine the circumstances affecting the consumption of working time, since without these data any use of time-values is very limited as stated earlier.

The final result of time study, the unit work $\left(t_{N}\right)$ of a job or a task is formed from the results measured and possibly from rated coefficients calculated according to the following formula (ANON. 1971 b):

$$
\text { (1) } t_{N}=\sum_{i=0}^{n}\left(t_{v_{i}} \times \quad k_{j_{i}}\right)
$$

where $t_{v}$ is the time value which is selected from the measurement results of a certain element to represent its time, the so-called selected time, and $\mathrm{k}_{\mathrm{j}}$ the 

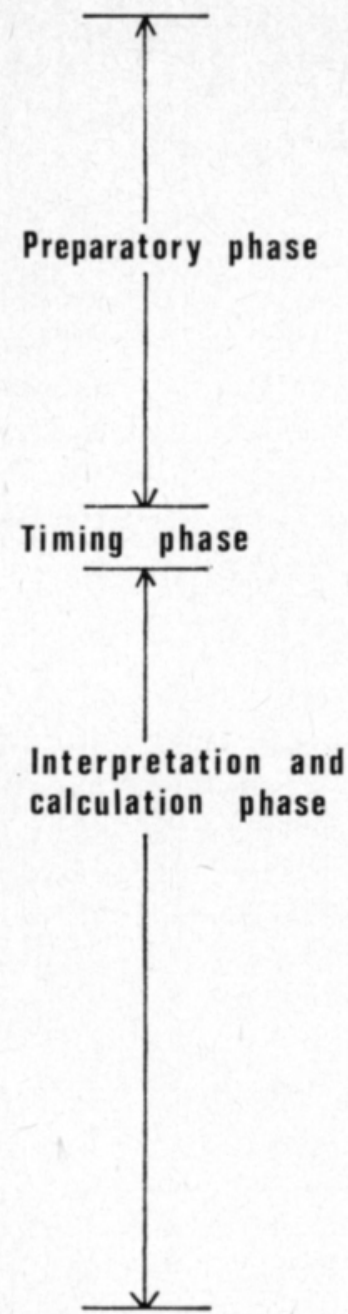

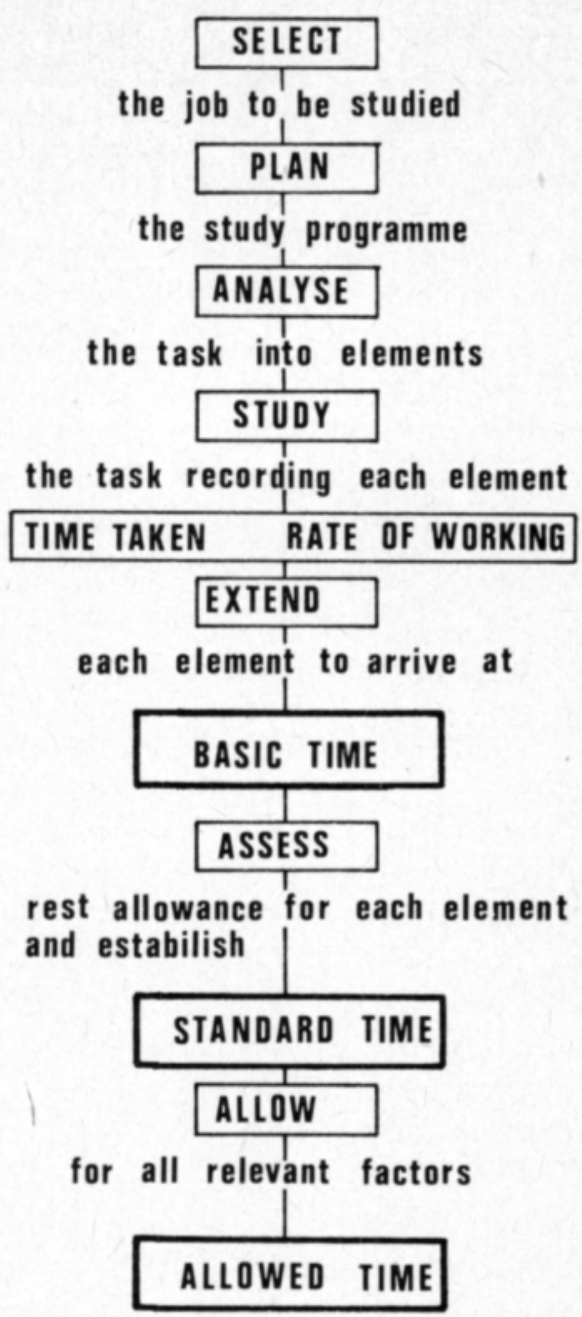

Figure 2. Time study procedure (BAKER 1976).

performance coefficient based on the rated performance. The standard time of a job is obtained according to Figure 1 (p. 9) by adding the corresponding allowance to the unit work.

In the opinion of TABERNACLE (1975) the fact that a certain accuracy is required beforehand of the results of work measurement does not necessarily signify that the accuracy of each element and coefficient has to meet that requirement. According to formula 1, the unit work is formed from the sum of the basic times of different work elements. The error of basic time of an individual element can be calculated according to formula 2 (ANON. 1970 a, SANDERS 1975):

$$
\text { (2) } \mathrm{p} \%= \pm \sqrt{\mathrm{p}_{1}^{2}+\mathrm{p}_{2}^{2}}
$$

where $p_{1}$ is the error in the first factor (selected time, $t_{v}$ ) of the product and $\mathrm{p}_{2}$ the error in the second factor (performance, $\mathrm{k}_{\mathrm{j}}$ ). 
The accuracy of the whole unit work of a job or task is determined by the accuracy of the individual elements by means of the following formula (3) (ANON 1970 a):

$$
\text { (3) } \dot{\mathrm{p}} \%= \pm \sqrt{\frac{\mathrm{a}_{1}{ }^{2} \mathrm{p}_{1}{ }^{2}+\mathrm{a}_{2}{ }^{2} \mathrm{p}_{2}{ }^{2}+\mathrm{a}_{3}{ }^{2} \mathrm{p}_{3}{ }^{2}+\ldots \mathrm{a}_{\mathrm{n}}{ }^{2} \mathrm{p}_{\mathrm{n}}{ }^{2}}{\left(\mathrm{a}_{1}+\mathrm{a}_{2}+\mathrm{a}_{3}+\ldots \mathrm{a}_{\mathrm{n}}\right)^{2}}}
$$

In the formula (3) $a_{i}$ is the basic time of element $i$ and $p_{i}$ the corresponding error according to the formula 2. It includes the errors in the timing and also in the possible coefficient. The formula shows that the accuracy of the final result is improved without improving the accuracy of individual work elements, when the basic times approach each other in magnitude.

Both formulas (2) and (3) are applications of general accuracy formulas, among others of those presented by BARFORD (1967).

\section{Accuracy of measurement}

Some uncertainty regarding the validity of the results is generally a feature in the measurement of all objects. In a normal measuring situation the true value of the object remains unknown. The measurement result is only an estimate. If the object to be measured is of a continuous type, it is generally not even possible to give the exact figure for the size. This is possible only in special cases, in which the object to be measured can be evenly divided by the measurement unit (DoEBelin 1966, p. 41, KARLSSON 1970).

In measurement technique the error is defined as the difference between the measurement result and the true value (e.g. DoEbelin 1966, p. 41, Kollar and KÜHN 1973). In this case accuracy means lack of error.

In a normal measuring situation the true value remains unknown, in which case the magnitude of the measuring error can not be calculated in accordance with the above definition. It is, however, generally possible to determine the precision of the measuring result using statistical control by determining, for example, the confidence limits of the final result (Doebelin 1966, p. 42, KARLSSON 1970, Kollar and KüHN 1973).

Measuring errors are generally divided into two main groups as follows (e.g. KaRLSSON 1970):

- systematical errors

- random errors

Some research workers, for example Grahm and Herz (1971, p. 13), classify in addition gross errors, due, for example, to careless reading or writing down, as yet another type of error. It seems justifiable, however, to classify them under the heading random errors.

A systematic error is due to imperfection in the measuring method and/or the equipment or its faulty use. In principle it is always equal in size to the specific value of the object measured in an identical situation. The effects of systematic errors can generally be eliminated from the final results with the use of correction coefficients.

The magnitude of random measuring errors is in principle not dependent on the measuring situation or the value of the object to be measured. It is 
thus not possible to eliminate their effect on the results by using correction coefficients etc. It is, however, possible to control the effect of random measuring errors by statistical methods. After the elimination of systematic errors, the mean value of the results is, according to BARFORD (1967), generally the best estimate of the true value.

The occurrence of random errors in the measurements is, according to KARLSSON (1970), quite natural. If in repeated measurement results of the same object no deviation is to be found, which generally resembles a normal distribution, the capacity of the measuring instrument has not been made full use of.

The measuring accuracy may be approached also from another angle than that of the difference between the measurement result and the corresponding true value. In that case the aim is to try and find out how far the individual measurement results deviate from the value that is considered to be the best estimate of the object. This is generally described with a standard deviation, which, according to BARFORD (1967), best describes this kind of precision. Analyses based on this method are in practice the only way of describing also the accuracy of measurement, because in a normal measuring situation the true value of the object remains unknown.

\section{Errors and inaccuracy in timing}

In time studies, as in other measurements, errors occur in the various phases. The errors pertaining to the timing may be divided, among others, into the following main groups (PechHold 1964, BäcKLIN et al. 1965, ÅBerg 1968, Kaminsky 1971, p. 178, TABernacle 1975):

- poor representativeness of sample

- changes in working method during study

- use of measurement method unsuitable in specific situation

- defects in measuring equipment

- errors made by the investigator

Among these the first and the second items are not connected with the actual timing process since they are connected with the selection of the object to be measured.

The accuracy of a time study depends, as stated above (p. 11), in addition to the accuracy of timing, also on other factors, e.g. accuracy of work specification and data that describe working conditions. Their influence on the accuracy of the final result varies depending on the situation in question.

In the definition of a time study presented earlier the point is underlined that the worker doing the studied job should be skilled and well trained for the job. These factors naturally influence the length of the time required to perform a job, in other words the magnitude of the result. On the other hand, they do not correspondingly influence the accuracy of the result. If the break point between two elements becomes blurred due to these factors, however, they may have a direct effect also on the measuring accuracy.

KraUse (1964), among others, is of the opinion that a definite break point is an essential factor in successful timing. Similarly, when a worker is unskilled 
the rating of a performance becomes more difficult and its accuracy diminishes.

With the use of normal manually operated instruments the timing point is removed from the break point owing to the reaction time of the investigator. The reaction time has been observed to vary between $0.17 \ldots 0.50 \mathrm{~s}$, and the advance notice preceding the break point has been found to cut it down on an average from $0.25 \mathrm{~s}$ to $0.20 \mathrm{~s}$ (MOEDE and RUPP, ref. KAMINSKY 1971, p. 179). It is assumed that the aelay due to the reaction time remains almost similar in length in each single timing so that it is not generally believed to affect the measuring accuracy (ANon. 1973, p. 89) .

In the measuring accuracy differences have been noted between different timing instruments and different investigators. When the measured times get shorter the relative accuracy gets poorer and the differences between the instruments grow larger (Lorenz 1962, Hammer and Al-Nawam 1973). The watch method has been found suitable providing the job breakdown does not involve elements that are too small (KAMINSKY 1971, p. 181).

In the use of read out type timing equipment in particular, the structure of the read out unit affects the accuracy of reading and the reading errors. According to ÅBER (1968), the reading errors made by a well trained investigator using a normal stop watch are generally less than $5 \%$. A considerable decrease in reading errors has generally been established when digital displays are used instead of the normal pointer display (HEINZ 1967, HäKKINEN 1970).

Regarding factors affecting the accuracy of the result in the timing phase, ÅBERG (1968) gives the following percentages which illustrate the changes in accuracy as proportional standard deviations:
- sampling method
$5 . .25 \%$
- measuring technique and
its application
$10 \ldots 50 \%$
- rating of performance
8. . $10 \%$

In his opinion the measuring technique and its application are thus essential factors affecting the accuracy of the measurement.

\section{Aim of the study}

With a few exceptions the methods applied in the determination of time standards in agriculture have not developed very much in Finland in the last few decades. The methods necessitate a considerable amount of man work and they do not give in all situations a reliable picture of the consumption of working time and factors that it is affected by. The problem is universal and by no means restricted only to agricultural jobs. Similar problems exist, for example, in work studies in industry (ZENKER 1970). ÅBERG (1968) holds the opinion that it is important to know the possibilities and limitations of the different time study techniques. The actual study methods should be speeded up and made more effective. The accuracy of the results should be known and likewise the factors that affect it.

The project dealing with work study methods in agriculture, and in particular methods usable in time studies based on the views outlined above, was 
instituted in 1971 at the Department of Agricultural Engineering, University of Helsinki. In the first phase prominence was given to the acquisition of basic knowledge concerning different time study techniques and instruments as well as factors affecting their accuracy.

The purpose of the present study is to give a comprehensive account of certain time study techniques used in agriculture, their accuracy and factors affecting it. It is based to a large extent on previously published results of the project (Penkonen 1973, 1975). The study aims at obtaining the answers primarily to two basic questions:

- the extent of accuracy in timing with the most commonly used time study techniques in different timing situations

- the most important factors that in practice affect the accuracy of timing The answers to these questions will have a decisive influence on the selection of a timing technique for each specific measuring situation. At the same time they constitute general basic knowledge for the development of time study methods.

\section{Performance of the study}

Several different factors may affect the measuring accuracy in the timing phase, as stated earlier (p. 15). In the test lay-out the measuring accuracy was influenced by variables grouped as follows:

- the jobs to be studied

- the measuring conditions

- time study methods and equipment

- the investigators

A division of these groups into entities is arbitrary. This applies in particular to measuring conditions, since the errors produced by them can be included also into the other groups. The error in the final measuring results is the total produced by these different factors.

\section{Collection of study material by simulation method}

So as to make possible a determination of the effects of the job and of the measuring conditions under study, the study was carried out in laboratory conditions, in which the different factors can be controlled more accurately than in a normal work situation. In order to calculate the measuring error in accordance with the definition, the true value of each separate element of the series of events to be measured has to be known. In normal measuring situations this is very rare. It is certainly possible to measure times with great accuracy, but in practice this takes a lot of time and is a costly process (e.g. Herb 1968, HaArlaa 1971). Consequently it was decided to make use of simulation instead of real work.

In the accuracy comparison of time study methods the following requirements were placed on the series of events describing the job adopted as the object of the study: 
- The order and duration of the different elements of the series of events must be changeable.

- The break point of two successive events must be momentary and unambiguous and the following event must start at exactly the same moment when the preceding one ends.

- It must be possible to determine the real duration of each event more accurately than is possible with the best studied method.

A so-called work study simulator, a simulation method that complied with these requirements, was constructed for the investigation. With the aid of the 16 lamps in its light panel (Fig. 3) it is possible to simulate the job under study (the lighting of a specific lamp represents a specific element of the job). The real lighting times of the lamps can be measured with an accuracy of approximately $1 / 1000 \mathrm{~min}$. A corresponding study method is in use also in the Federal Republic of Germany (Hammer and Al-Nawam 1973). This fact became known to us only after the completion of our own equipment.

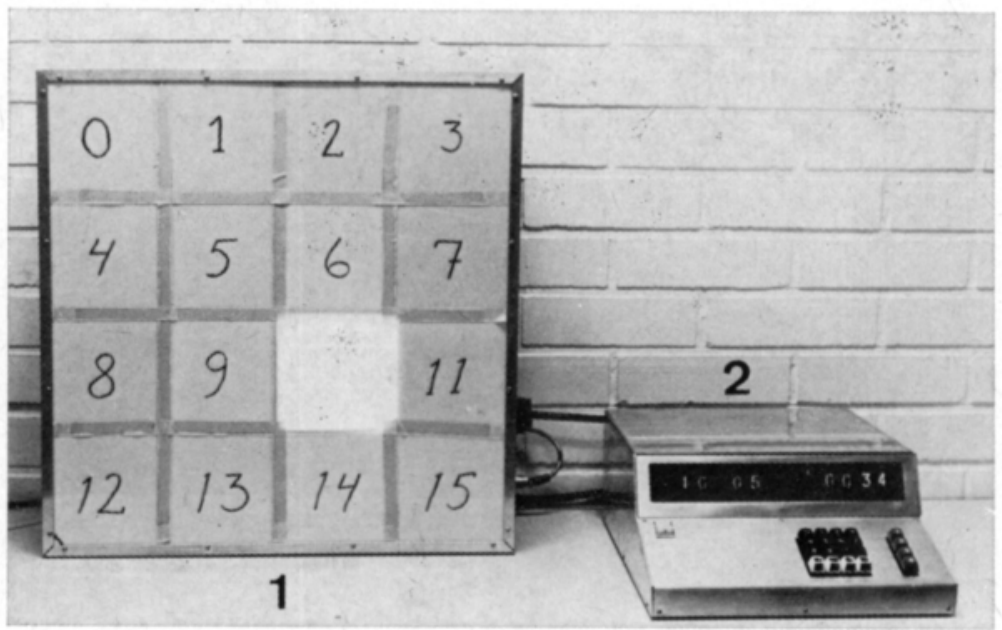

Figure 3. Work Study Simulator.

1: Light panel

2: Control and timing unit

In the work study simulator the lighting order and lighting time of the lamps can be changed by manual control. Automatic measuring of times is based on the frequency of the network, which during the study period remained almost constant, $50 \pm 0,1 \mathrm{~Hz}$. The construction and functioning of the simulator and the measuring accuracy it achieves are presented in greater detail in the first report of the project (PEHKONEN 1973).

The measuring result of the event obtained from the work study simulator, from the lighting time of a specific lamp, is in this connection compared with the true value of the time in question, although absolute certainty does not exist regarding the latter, which, after all, has also been obtained by measuring. Its accuracy $(1 / 1000 \mathrm{~min} \pm 0.2 \%)$ is, however, clearly better than $1 / 100 \mathrm{~min}$ which represents what can be achieved by studied instruments. It consequently 
appears justifiable to rank the result produced by the work study simulator in the same category with the true value of the time, which, hereafter, will be called the master value.

\section{On the analogy between simulation and normal work as a study object}

The analogy between simulated and normal work as a study object has not been experimentally examined in connection with the present study. Nor have Hammer and Al-Nawam (1973) carried out tests in this matter. In their opinion the difference between observed and real time in simulated work study is at least not smaller than in a study of a normal job.

In the present study, in connection with the human factors material (see Ch. 22), each test person filled in a questionnaire in which their opinion on simulation was requested in two separate questions. Judging by the replies received, some $60 \%$ of the test persons were of the opinion that simulation as a study object was at least relatively analoguous with normal work. Only some $6 \%$ held the opinion that there was no analogy whatever. Among the test persons those with practical experience in time studies were somewhat more critical than the others as regards analogy (PEHKONEN 1975).

From the point of view of measuring accuracy, $37 \%$ of the test persons considered simulation more difficult to study than normal work, $34 \%$ considered the difficulty degree to be equal and $29 \%$ regarded it as being easier. Among the test persons that had been previously engaged in work studies, $45 \%$ believed that simulation was more difficult to study than normal work and only $12 \%$ considered it to be easier (PEHKONEN 1975).

The opinions of the test persons revealed by the questionnaires served to strengthen the notions presented by Hammer and AL-Nawam (1973) and PEHKonen (1973). In simulation the measuring accuracy does at least not seem to improve when compared to normal work. Thus the results obtained with the aid of a work study simulator in laboratory conditions may, with certain reservations, be applied also to corresponding measuring situations in normal time studies.

\section{Study material}

The study material is composed of the results of two separate test series. The laboratory tests of the first part were carried out at the Department of Agricultural Engineering, University of Helsinki. They lasted from the autumn of 1972 to the spring of 1973 . The test series was designed to elucidate the way the various factors affect the measuring accuracy in the timing phase. The material for the second part was collected in 1973 and 1974 on the work study courses organised by Rastor and Tietomies. They were designed to throw further light on the influence of various human factors, which in the results of the first part proved to be essential factors.

In the first part, which will hereafter be called the basic material, there were four groups of variables conforming to the bases of the experimental layout: 
the test persons, time study methods and equipment, measuring conditions, and jobs to be studied. Eight persons took part in the study: two assistants of the Department and six senior students.

The following time study equipment (Fig. 4) and methods were used:

1. Work study printer Chronaprint, which prints out the times at an accuracy of centiminutes $(=1 / 100 \mathrm{~min})$ on a paper tape at the pressing down of an operational lever. The code of the element and other possible annotations have to be written down in pencil.

Figure 4. Time study equipment

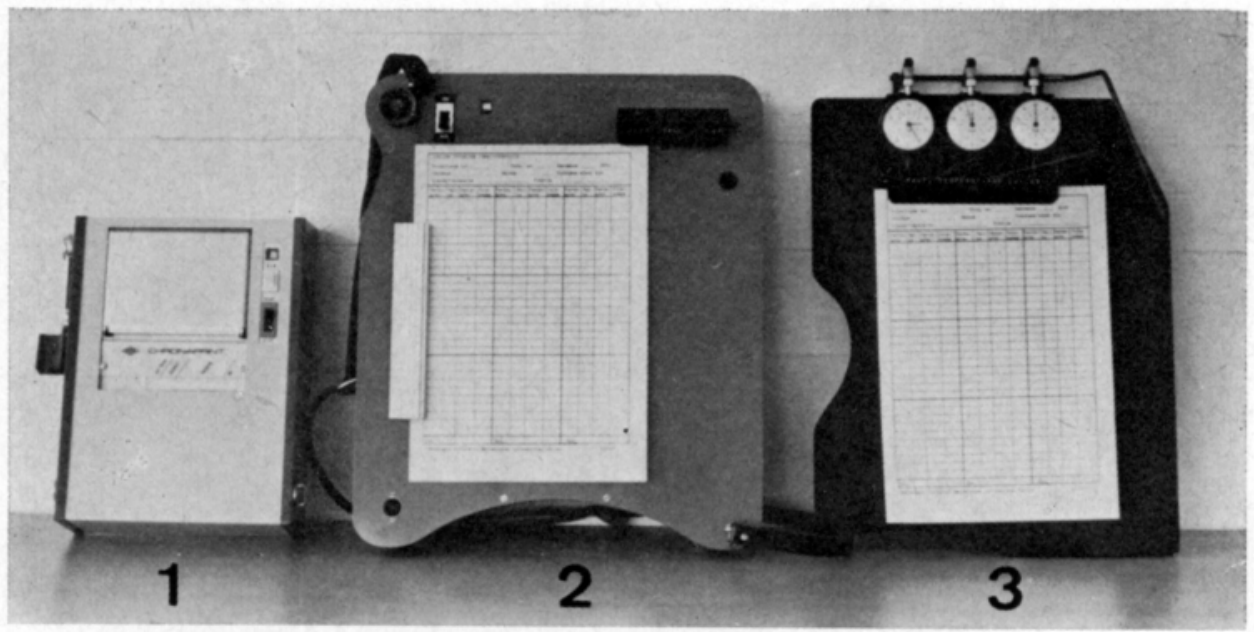

1. Work study printer Chronaprint

2. Work study watch Chronarith with digital display

3. Combination board Heuer with three watches

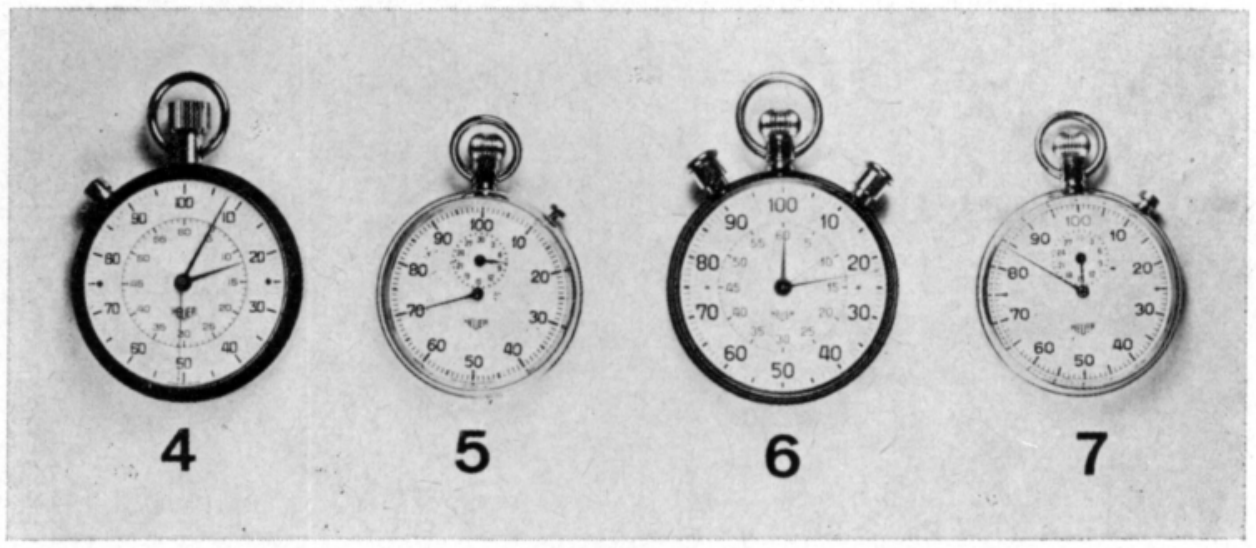

Heuer work study watches

4. Taylor-watch

5. Normal stop watch

6. Work study watch with split action for cumulative timing

7. Normal stop watch (similar to 5) used in accordance with cumulative timing 
2. Work study watch Chronarith with digital display. This gives the times of the elements in centiminutes on either of the two part-time counters.

3. Combination board Heuer with three time study watches. The measurement result may be read out in centiminutes from any one of the three watches with the pointer stopped.

4. Time study watch Heuer with split action, suitable for fly-back timing. In this so-called Taylor-watch the results are indicated by a stopped follower pointer in centiminutes.

5. Normal stop watch with centiminute meter scale where the result has to be read out by a moving pointer at the moment preceding the fly-back to zero.

6. Heuer watch with split action and centiminute meter scale suitable for the cumulative timing method. The results can be read out from the stopped follower pointer.

7. Normal stop watch Heuer (similar to watch No. 5) used in accordance with the cumulative timing method.

With equipment $1 \ldots 5$ the result is directly observed time and with watches 6 and 7 the result is achieved by subtraction. With equipment No. 1 the form of output was simply a print out, supplemented by code marks in pencil. With watches $2 \ldots 7$ two different kinds of output systems were used: normal writing down, and punching on preperforated punched cards with IBM's Port-a-punch punching device (Fig. 5).

Figure 5. IBM's Port-a-punch punching device.

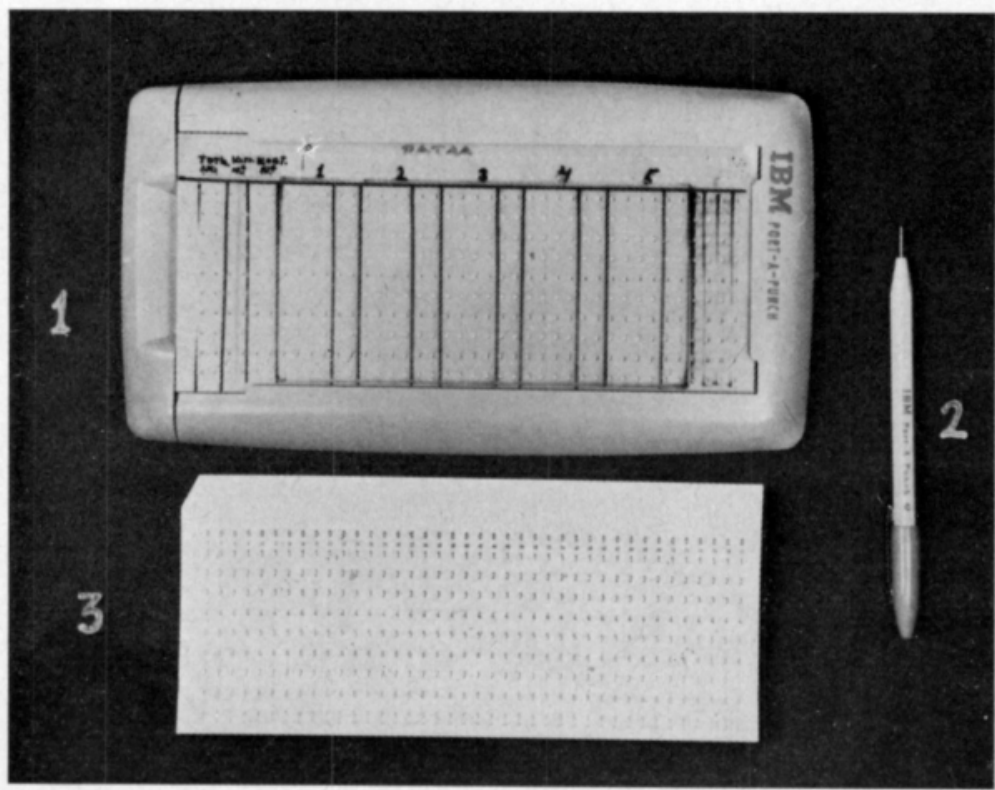

1. Punching frame

2. Punching stick

3. Unpunched preperforated punched card 
The experimental layout with its variables has been described in detail in the first report of the study project (Penkonen 1973). Some 7400 separate times (master values), varying from 3 to $115 \mathrm{cmin}$, were measured in the basic material. Their total time amounted to approximately $29 \mathrm{~h}$ giving an average of $23 \mathrm{cmin}$ to the master value. With different equipment their total valid measuring results in the study amount to 39255 , which hereafter will be called measured values.

The measuring accuracy was affected to a surprising extent by the way the results were recorded. Consequently, to facilitate the process of analysis, the basic material was divided into two parts: results printed out or written down in pencil, and results punched with a punching device on preperforated punched cards. There were 37548 normally recorded times and 1707 punched ones.

In the second part, hereafter called the human factors material, there were a total of 177 test persons. Each one of them measured with a normal stop watch with fly-back timing a total of 150 times of $4 \ldots 32 \mathrm{cmin}$ (average 14 cmin) during two tests of approximately $10 \mathrm{~min}$ duration. The human factors material thus consists of 26550 measured values. On each of the seven work study courses during which the studies were carried out, the study was at the same time a test in the use of stop watches that formed part of the examination requirements.

In connection with the collecting of the human factors material, each test person filled in a questionnaire listing questions on their opinion regarding the analogy of simulation and normal work as a study object (see Ch. 211, p. 19), on their experience in work studies and their views as to their own level of training in the performance of time studies. In addition it was possible to use the test results of the $\mathbf{1 1 5}$ test persons participating in the suitability tests in order to illustrate certain characteristics of the test persons.

Since this part-material was designed to examine primarily the effect of human factors on the measuring accuracy, the test layout was planned in accordance with the principles of proof of skill tests of, among others, GHISELLI and Brown (1969, p. 86) in such a way that external factors would influence the measuring accuracy to the least possible extent. For this reason only one type of equipment, the normal stop watch, was used in the human factors material. In addition the series of events to be studied and the study conditions were kept constant in so far as possible. The details of the test layout have been presented in the study report of the second part of the project (PEHKoneN 1975).

\section{Representativeness of the material}

The materials do not constitute a statistical sample of any population. As test persons for the basic material were selected persons available in the Department, who had theoretical knowledge of work studies acquired during their studies in agricultural engineering as well as some practical experience. The test persons in the human factors material were students from the work study courses of Rastor and Tietomies, who had been sent to the courses by 
their employers or who had enrolled of their own accord. On an average, these persons had a rather limited knowledge of work studies before attending the course. At the completion of the course they may be regarded as corresponding in knowledge and skill on an average to a work study person in the early stages of his career.

The timing instruments used in the study chiefly represented types that are generally used in the studies of agricultural jobs. In addition some instruments rarely used in agriculture were included since, according to the literature, they represented an improvement in the measuring accuracy as well as in the calculation of results. The simulated jobs as well as the study conditions do not directly correspond to any specific agricultural jobs. Within the limits of the technical restrictions they were selected in such a way that the results would yield information on as many different situations as possible.

The results of the study do not, accordingly, aim at representing any average measuring accuracy attainable in time studies in practice, and indeed this had not been the original intention either (see Ch. 13. p. 16). On the basis of the materials it is, on the other hand, possible to obtain information pertaining to the central questions of the study and the results thus obtained are applicable also in practice.

\section{Handling of the material}

The handling of both of the part-materials was carried out in the Computing Centre, University of Helsinki. In the actual analysis phase library programmes of the Hylps-system were used in accordance with each correspondingly valid version (ANON. 1972 a, 1974 b, 1976).

In the early stage the materials were transferred onto punched cards in such a way that the master values and the measured values with their respective background data were placed on separate cards. From these so-called rough materials were formed the actual study materials by calculating the measuring errors of each single measurement and by forming the other required aid and grouping variables. For these transforming stages a Fortran-language programme was compiled, which recorded the observation matrix onto magnetic tape in a form suitable to be input data for the Hylps-system. At this stage the observation matrix of the basic material included 18 variables and the matrix of the human factors material 36 variables.

At the beginning of the analysis stage, the means of the dependent variables were calculated in accordance with the tabulation programme and likewise the standard deviations in the various classes of the independent variables. The significance of the possible differences was likewise subjected to a variance analysis. A correlation matrix was compiled in addition, and information that had remained disconnected at the tabulation stage was made compact by factor analysis, which JärVELÄINEN (1971) and SäNKIAHO (1974), among others, consider a suitable method for this kind of purpose. On the basis of the human factors material a so-called mean matrix was further compiled, in which the variables consisted of the means of the different variables calculated by each test person's observation results as well as the standard deviations of the quantitative criteria of the measuring accuracies (see Ch. 23). 
On the basis of the results of these phases it was hoped to obtain an explaining model based on regression analysis for the changes in measuring accuracy. Regression analysis was adopted as the method used since with the independent variables conforming at least to an ordinal scale it could be expected to give a clearer picture than variance analysis of the simultaneous effect of the different variables.

For the present publication the results of the basic material have been calculated anew and earlier analyses have been completed mainly in accordance with information originating in the human factors material. As regards the human factors material, the results are based on the published data in the second part of the project (PEHKONEN 1975).

\section{On the criteria of the measuring accuracy}

Quantitatively the measuring accuracy (deviation of the measured value from the master value) is described by calculating in each separate timing the absolute measuring error (= measured value - master value), the absolute deviation (= absolute value of the measuring error) and the proportional measuring error and deviation. If the time of some event has not been measured or recorded (so-called missing time), the result has been accorded the figure zero at the calculation stage. In the missing times the absolute measuring error is thus $=-$ master value, and the absolute deviation $=$ master value.

Quantitatively the measuring accuracy was described by four separate criteria since one could not be sure in advance which of them would in practice best describe the measuring accuracy. All four have a clear dependence since they describe the same thing. In specific stiuations they do, however, give clearly differing pictures of the measuring accuracy. The proportion of missing times and their magnitude affect in fly-back timing directly the absolute measuring error. In cumulative timing, on the other hand, the master value corresponding to the missing time does in its entirety get transferred to the following measured time so that the missing times do not affect the mean absolute measuring error. In the mean matrix composed of the human factors material standard deviations of the above quantitative variables have in addition been used to describe the variations in the measurement accuracies of the test persons.

In the study the mean measuring error is generally negative owing to the missing times, among other things. Since the value of the negative measuring error consequently approaches closer to zero, in other words the measuring accuracy improves, the mathematical value of the measuring error grows larger. The definition of the result, decrease in the measuring error, is thus not the mathematically correct one although it is used because it is descriptive and simple.

As the unit denoting an absolute measuring error and deviation has been used a centiminute $(1 \mathrm{cmin}=1 / 100 \mathrm{~min})$ despite it not being a value conforming to the SI-system. In time studies it is, however, still widely used, for example all the time study instruments used in the present study gave the results in centiminutes. 
The qualitative measuring accuracy has been described with the following dichotomic variables:

- Missing time, i.e. time that has not been measured and/or recorded. In such a case the absolute deviation = master value.

$-5 / 10$ error. In reading the watch a mistake has been made in the annotations of the $\mathbf{5}$ and $\mathbf{1 0}$ marks in the scale. The absolute deviation is thus $\mathbf{5}$ or $10 \mathrm{cmin} \pm$ the permitted error limit $1.6 \mathrm{cmin}$, which is the maximum rounding error $0.5 \mathrm{cmin}+$ maximum error of master value $0.1 \mathrm{cmin}$ (PEHKonen 1973) + an error of one centiminute which is considered normal (РеCHнLD 1964).

- Gross error. The error is considered gross when the absolute deviation exceeds $10 \mathrm{cmin}$.

- Faultless measuring result of the measured value when the absolute deviation does not exceed $0.6 \mathrm{cmin}$.

In addition to these variables denoting qualitative errors in the results, each timing has included a check-up of the correctness of the recording of the code of the respective element.

Each of these alternatives describing the qualitative measuring errors eliminate the other alternatives in question. In the results of the tabulation stage the means of the respective variables are given as 100 -fold, thus denoting the percentual proportion of this type of error in the material. However, as the percentages are based on the mean values of the dichotomic variables, it has also in these cases been possible to test the significance of the differences with variance analysis.

Table 1. Proportions of variances explained by qualitative criteria of measuring accuracy in the linear regression models of quantitative criteria of measuring accuracy.

\begin{tabular}{|c|c|c|c|c|}
\hline \multirow[b]{2}{*}{ Part of material } & \multicolumn{4}{|c|}{ Explanation \% } \\
\hline & $\begin{array}{c}\text { Absolute } \\
\text { measuring } \\
\text { error }\end{array}$ & $\begin{array}{l}\text { Absolute } \\
\text { deviation }\end{array}$ & $\begin{array}{c}\text { Proportional } \\
\text { measuring } \\
\text { error }\end{array}$ & $\begin{array}{c}\text { Proportional } \\
\text { deviation }\end{array}$ \\
\hline Total basic material .......................... & 29.3 & 60.8 & 32.0 & 57.6 \\
\hline $\begin{array}{l}\text { All normally recorded results ................ } \\
\text { Measured and normally recorded }\end{array}$ & 25.8 & 58.8 & 28.0 & 55.8 \\
\hline 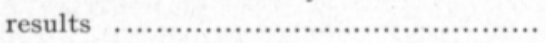 & 5.7 & 63.0 & 8.7 & 41.7 \\
\hline 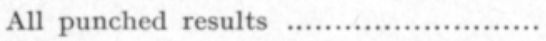 & 40.4 & 63.4 & 49.8 & 64.1 \\
\hline Measured and punched results ............. & 20.9 & 60.7 & 23.8 & 48.2 \\
\hline
\end{tabular}

In both materials the deviation denotes the presence in the results of various kinds of qualitative errors better than does the measuring error (Table 1). With the linear regression model, in which the independent variables were the variables indicating the presence of the aforementioned qualitative errors, it was possible in the basic material to explain some $30 \%$ of the variation in the measuring error and some $60 \%$ of the variations in the deviation, and in the human factors material some $50 \%$ of the measuring error and almost $80 \%$ of the deviation (PEHKONEN 1975). 
In the mean matrix of the human factors material the absolute measuring error and its standard deviation explain some $80 \%$ of the variation in the absolute deviation (PeHKonen 1975). The deviation thus gives a relatively reliable picture also of the measuring error (though not of its direction) and of its standard deviation. According to these results it is justifiable, when using one criterion, to describe the quantitative measuring accuracy as a deviation. In such a case it is advisable to use its absolute value since the time to be measured does not here affect mathematically the magnitude of the result.

\section{Measuring accuracy and factors affecting it reviewed in the light of study results}

Expressed in different criteria the average measuring accuracy conforms with Table 2. In the basic material the absolute deviation was on an average $1.31 \mathrm{cmin}$, in its normally recorded results $1.12 \mathrm{cmin}$ and in punched results

Table 2. Average measuring accuracy in individual materials.

\begin{tabular}{|c|c|c|c|c|c|c|c|}
\hline \multirow[t]{3}{*}{$\begin{array}{l}\text { Criteria of } \\
\text { measuring accuracy }\end{array}$} & \multicolumn{4}{|c|}{ Basic material } & \multirow{3}{*}{ Average } & \multicolumn{2}{|c|}{$\begin{array}{c}\text { Human factor } \\
\text { material }\end{array}$} \\
\hline & \multicolumn{2}{|c|}{$\begin{array}{l}\text { Normally recorded } \\
\text { results }\end{array}$} & \multicolumn{2}{|c|}{ Punched results } & & \multirow[t]{2}{*}{$\begin{array}{c}\text { All } \\
\text { times }\end{array}$} & \multirow[t]{2}{*}{$\begin{array}{l}\text { Measured } \\
\text { times }\end{array}$} \\
\hline & $\begin{array}{c}\text { All } \\
\text { times }\end{array}$ & $\begin{array}{l}\text { Measured } \\
\text { times }\end{array}$ & $\begin{array}{c}\text { All } \\
\text { times }\end{array}$ & $\begin{array}{l}\text { Measured } \\
\text { times }\end{array}$ & & & \\
\hline \multicolumn{8}{|l|}{ Abs. measuring error } \\
\hline$\overline{\mathrm{x}} \mathrm{cmin} /$ measurement & -0.39 & -0.12 & -1.86 & 0.89 & -0.45 & -0.53 & -0.27 \\
\hline $\mathbf{s}$ & 4.26 & 3.21 & 13.18 & 10.83 & 5.00 & 2.23 & 1.45 \\
\hline \multicolumn{8}{|l|}{ Prop. measuring error } \\
\hline$\%$ & -1.51 & -0.14 & -7.87 & 5.73 & -1.79 & -3.86 & -1.31 \\
\hline $\mathbf{s}$ & 26.44 & 23.06 & 58.36 & 49.21 & 28.61 & 21.53 & 14.84 \\
\hline \multicolumn{8}{|l|}{ Abs. deviation } \\
\hline$\overline{\mathrm{x}} \mathrm{cmin} /$ measurement & 1.12 & 0.85 & 5.53 & 3.17 & 1.31 & 1.06 & 0.81 \\
\hline $\mathbf{s}$ & 4.12 & 3.10 & 12.10 & 10.39 & 4.84 & 2.03 & 1.23 \\
\hline \multicolumn{8}{|l|}{ Prop. deviation } \\
\hline$\%$ & 7.51 & 5.82 & 25.07 & 13.46 & 8.27 & 9.41 & 6.97 \\
\hline $\mathbf{s}$ & 25.40 & 22.31 & 53.28 & 47.68 & 27.44 & 19.74 & 13.17 \\
\hline \multicolumn{8}{|l|}{ Missing times } \\
\hline$\%$ & 1.79 & - & 13.42 & - & 2.30 & 2.68 & - \\
\hline $\mathbf{s}$ & 13.26 & - & 34.09 & - & 14.98 & 15.98 & - \\
\hline \multicolumn{8}{|l|}{$5 / 10$-errors } \\
\hline$\%$ & 1.72 & 1.75 & 7.21 & 8.32 & 1.95 & 2.77 & 2.84 \\
\hline $\mathbf{s}$ & 12.98 & 13.10 & 25.86 & 27.63 & 13.84 & 16.41 & 16.62 \\
\hline \multicolumn{8}{|l|}{ Gross errors } \\
\hline$\%$ & 0.50 & 0.50 & 4.22 & 4.87 & 0.66 & 0.08 & 0.09 \\
\hline $\mathbf{s}$ & 7.02 & 7.08 & 20.11 & 21.53 & 0.08 & 2.88 & 2.92 \\
\hline Total of observations & 37548 & 36876 & 1707 & 1478 & 39255 & 26550 & 25854 \\
\hline
\end{tabular}


$5.53 \mathrm{cmin}$ per timing. In the human factors material the absolute deviation, $1.06 \mathrm{cmin}$ per timing, was somewhat smaller than in the normally recorded results of the basic material. In the punched results of the basic material the measuring accuracy was clearly poorer than in other parts of the material. In this part material a majority of the so-called 5/10 errors, however, is due to other reasons than the mixing of the marks 5 and 10 on the scale when reading out the results.

The average figures presented in Table 2 give a certain total picture of the measuring accuracy. In the basic material, in particular, they do not, however, give a clear picture of the measuring accuracy of individual times. The picture becomes considerably clearer when the distribution of the results into error categories presented in Table 3 is studied. In normally recorded results, the error in some $64 \%$ of them may primarily be regarded as a rounding error. If, further, an error of one centiminute is regarded as a normal inaccuracy (PEChHold 1964), more than $90 \%$ of the measured values should be regarded as correctly taken timings. In the human factors material the corresponding figures are $58 \%$ and $\mathbf{8 8} \%$ (PEHKONEN 1975).

Table 3. Distribution of individual measuring results in basic material.

\begin{tabular}{|c|c|c|c|c|c|c|}
\hline \multirow[b]{2}{*}{$\begin{array}{l}\text { Abs. deviation } \\
\text { cmin/measurement }\end{array}$} & \multicolumn{3}{|c|}{ Normally recored results } & \multicolumn{3}{|c|}{ Punched results } \\
\hline & $\begin{array}{c}\text { Mean of } \\
\text { group cmin }\end{array}$ & $\%$ & $\begin{array}{c}\text { Cumulative } \\
\%\end{array}$ & $\begin{array}{l}\text { Mean of } \\
\text { group cmin }\end{array}$ & $\%$ & $\begin{array}{c}\text { Cumulative } \\
\%\end{array}$ \\
\hline $0.0 \ldots 0.6$ & 0.28 & 64.0 & 64.1 & 0.28 & 40.3 & 40.4 \\
\hline $0.7 \ldots 1.6$ & 0.96 & 27.2 & 91.2 & 1.05 & 24.7 & 65.0 \\
\hline $1.7 \ldots 2.6$ & 2.03 & 3.7 & 94.9 & 2.06 & 7.1 & 72.1 \\
\hline $2.7 \ldots 3.4$ & 2.98 & 0.8 & 95.7 & 2.96 & 1.9 & 74.0 \\
\hline $3.5 \ldots 6.6$ & 4.94 & 1.8 & 97.5 & 4.73 & 4.9 & 78.9 \\
\hline $6.7 \ldots 8.4$ & 7.48 & 0.5 & 98.0 & 7.54 & 2.5 & 81.4 \\
\hline $8.5 \ldots 11.6$ & 9.94 & 0.6 & 98.6 & 9.77 & 4.3 & 85.7 \\
\hline over $\quad 11.6$ & 28.67 & 1.4 & 100.0 & 28.81 & 14.3 & 100.0 \\
\hline Average/total & 1.12 & 100.0 & & 5.53 & 100.0 & \\
\hline
\end{tabular}

In the work elements marked with the same code there were errors in both directions, consequently the accuracy of the final results of the time study would be an improvement on the figures based on the aforementioned deviation. In judging the measuring accuracy on the basis of the criteria used in the study it should further be taken into consideration that in master values the accuracy output is set at $1 / 1000 \mathrm{~min}$ and in the measured values at 1/100 min. Owing to the construction and operating method of the work study simulator, the last decimal for the master value repeats each one of the figures $0 \ldots 9$ approximately an equal number of times. Even if the measured times had been taken at an accuracy of 1/100 min without any errors, a rounding error of a magnitude of $-0.5 \ldots+0.5 \mathrm{cmin}$ per timing would have entered the results. With rounding errors of different magnitudes appearing approximately an equal number of times, they increase the average absolute deviation by approximately $0.25 \mathrm{cmin}$. 
Most of the test persons had very limited training in the carrying out of time studies (see Ch. 3313, p. 38). In the basic material, in which each test person performed some $\mathbf{5 0 0 0}$ measurements, their skill increased during the study (PEHKONEN 1973). In the human factors material the test series involved only 150 measurements per person, which probably did not affect the level of training.

In view of the above, the average measuring accuracy recorded in the study must be considered at least satisfactory in the human factors material and in the normally recorded results of the basic material. In the punched results the measuring accuracy remained poor, in particular the proportion of missing times was high.

\section{Simulated jobs and study conditions}

Different simulated jobs and study conditions affected the measuring accuracy only in the normally recorded results of the basic material. In the punched results their effect, which as a whole is rather limited, is almost entirely obscured by other factors.

The work type, in other words the regularity with which the different elements of the job occur in simulation, did not affect the measuring error. On the deviation it had an apparent effect, which is fully explained by the dependence between the work type and other independent variables (РEнкоNEN 1973).

The length of the observed time clearly affected the measuring accuracy. When the master values became shorter, below $10 \mathrm{cmin}$, there was a sharp increase in the proportion of the missing times (Fig. 6), though not in the same proportion as with the master value. The mean absolute deviation consequently grew with a lengthening of the observed time. With the exception of the last category, the absolute deviation of measured times was approximately the same in all master value categories (Fig. 7). The relative deviation, on the other hand, showed a clear increase when the master value dropped to less than $15 \mathrm{cmin}$.

The surprising growth in the absolute deviation in the master value category, $25 \ldots 50 \mathrm{cmin}$, is probably due to the so-called parallaxial error in the use of read out type time study equipment. When the results have been read out the watch has been in a diagonal position so that systematically erroneous results have been obtained in this category of master values. The result produced by the human factors material (PEHKONEN 1975) further strengthens this assumption.

In the largest master value category the absolute deviation shows a surprisingly large increase. This may be partly accounted for also by the parallaxial error. Similarly, as noted earlier in the cumulative timing, the result after missing time is affected by an error as big as the master value of the missing time, because when in cumulative timing some element is not measured the following element will be a joint sum of both elements. In simulation, in addition, the work element changes to another element abruptly without it being possible to observe in advance the approaching of the break point, which 
Figure 6. Absolute deviation and share of missing times in individual groups of basic times in normally recorded results of basic material.

Abs. deviation

$\mathrm{cmin} /$ measurement

Missing times

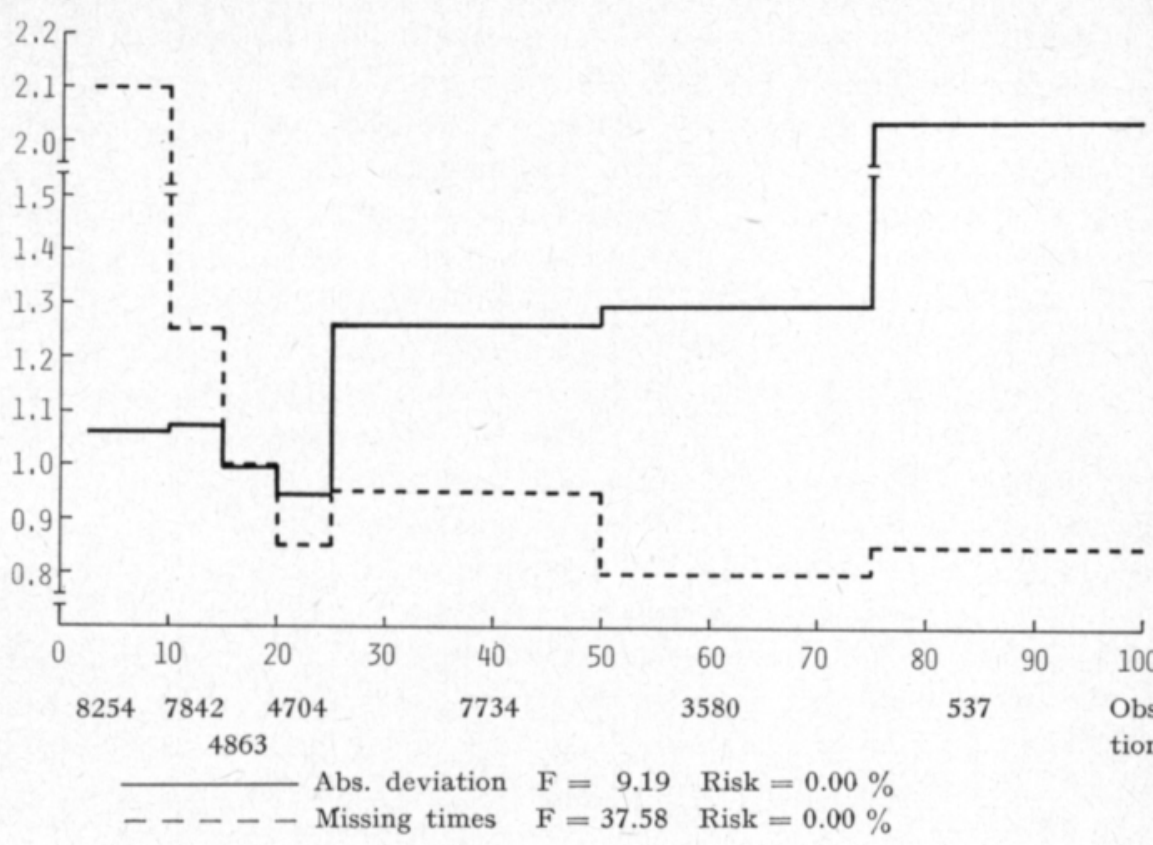

Figure 7. Abs. and prop. deviation in individual categories of measured and normally recorded times in basic material.

Abs. deviation

cmin/measurement

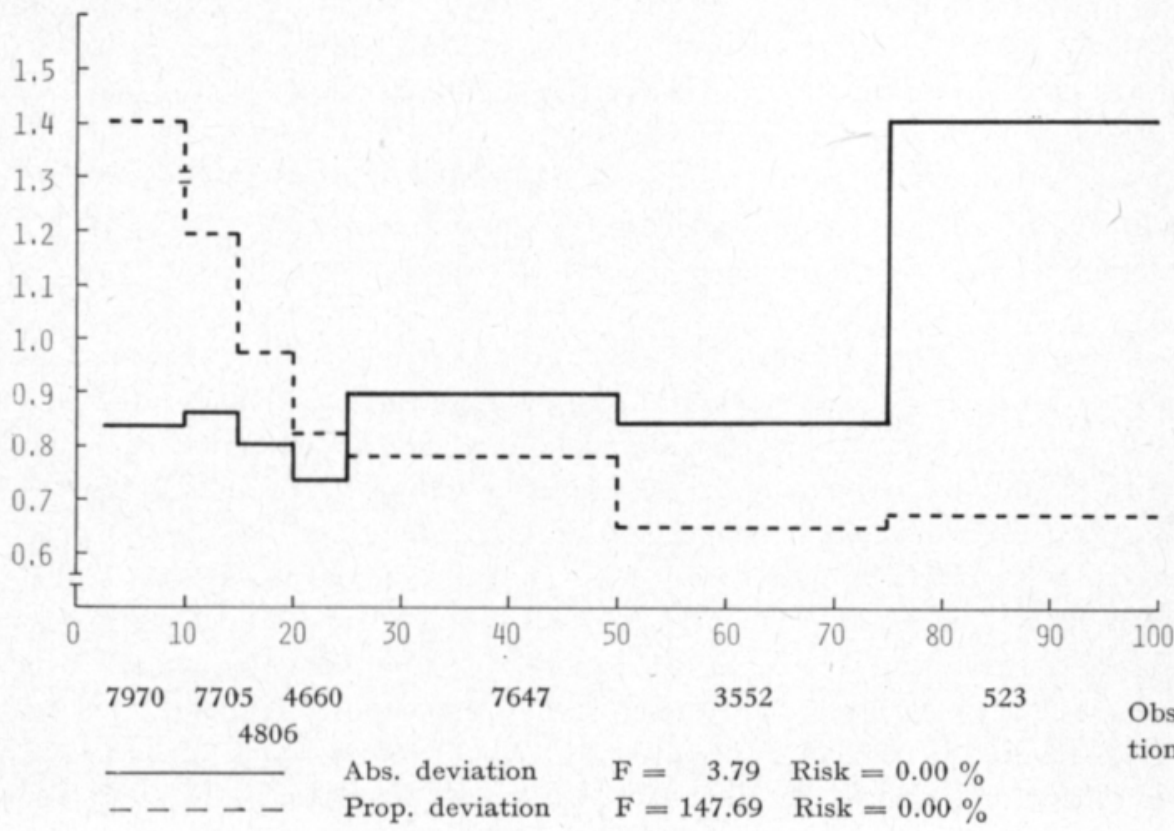

Prop. deviation $\%$

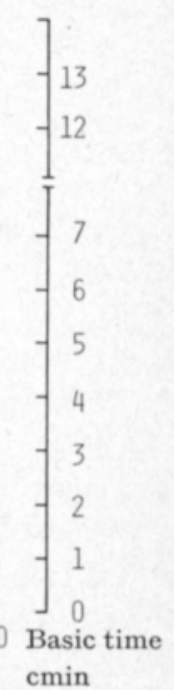

Observa-

tions/group 
is generally possible in a time study carried out with a normal job. This has apparently also affected the measuring accuracy.

According to the results it is possible to influence the measuring accuracy by applying a job breakdown. It is advisable to avoid the use of very small work elements in time studies even if it makes the work specification more detailed, since it has an adverse effect on the actual measuring accuracy. In particular the missing times make the sample and so also the result less representative. The proportional measuring accuracy likewise declines sharply. The lower limit of the element times to be measured suitable for the test persons would have been $15 \ldots 20 \mathrm{cmin}$. In his article HeInz (1967) proposes approximately similar limits. In regard to master values above $75 \mathrm{cmin}$, the study result is not suitable for generalisation owing to the aforementioned exceptional factor. However, judging by the present study as well as the results presented by PechHold (1964), it seems evident that the use of long work elements does not improve the absolute measuring accuracy.

The measuring accuracy was affected by different external circumstances at the place of study. In addition to circumstances corresponding to normal office conditions, the study was also performed in noisy (about $95 \mathrm{dBA}$ ) and in dimly lit (about 15 lux) conditions and in simultaneously noisy and dimly lit conditions. Noise alone did not significantly affect the deviation. It did, however, cause a slight increase in the number of qualitative errors. Dim light caused a drop in the deviation as well as in the proportion of various kinds of qualitative errors, particularly those of missing times (from $1.9 \%$ to $0.8 \%$ ). The results obtained in conditions that were simultaneously noisy and dimly lit corresponded primarily with results achieved in dimly lit condittions.

The rather surprising effects brought about by the prevailing conditions are evidently connected with the following factors:

- Conditions deviating from the normal were placed towards the end of the study by which time the test persons had had more experience.

- The possible disturbing effect of noise was diminished by the fact that the test persons used cuptype ear protectors.

- The dim light made it easier to observe the break point on the light panel.

- In dim light, and in simultaneously noisy and dim light conditions, the test persons made a better than normal concentration effort in their timings.

In normal conditions the test persons were able to see what happened in their surroundings and it is evident that these external events have absorbed part of their receptivity to information, which, again, has contributed to an increase in the number of errors. The test result is in line with results presented by HÄKKINEN (1970) regarding the reception of information. In dim light the test persons were totally isolated from their surroundings as regards visibility.

In a normal time study, in contrast to a simulated job, the possibility to observe the break point gets more difficult at the dimming of the light. The obtained result concerning the effect of lighting should therefore not be considered generally applicable in practice. Nevertheless, it is of practical use of another kind. It underlines the importance of the clearness of the break 
point, as has been noted by Krause (1964) among others. An effect on the same lines became apparent also in another way. An advance alarm given by a buzzer before the break point improved the measuring accuracy and reduced particularly the share of missing times. On the other hand, when the test person was far from the simulator and the observation of the break point was more than normally difficult, the measuring accuracy declined.

The results show that when the break point is clearly discernible at work, and when its approach can be observed in advance, there is an improvement in the measuring accuracy. In work measurements in practice these points have to be taken in consideration when planning job breakdowns, in addition to other factors that are involved (Olkkonen and Aulanko 1972).

\section{Time study equipment and methods}

The equipment used for time measurement had a clear effect on the measuring accuracy in results written down normally (Tables 4 and 5) as well as in punched results (Table 6). In direct observed times (equipment $1 \ldots 5$ ) and in cumulative timing (equipment 6 and 7) the results are not in all parts directly comparable. In the cumulative timing the master value corresponding to the missing time is transferred to the following measured time, as has been stated earlier. Their effect consequently extends also to the measured times, which can be seen very clearly particularly in the punched results. When their effect is eliminated, the results obtained by the cumulative timing compare in accuracy with the results of corresponding direct observed times, which agrees with the results of $\operatorname{HilF}(1975$, p. 229).

Among the tested equipment the measuring accuracy of the printer proved clearly poorer than had been expected on the basis of results presented, among others, by Heinz (1967). In particular, the proportion of missing times proved to be high. Generally times remained unmeasured owing to operational disturbances in the equipment. In the printer used in the study, the operational lever had to be pressed right down at a certain speed and kept down for a sufficient length of time. A quick pressing down could mix up the timing of the printing mechanism of the time counter to such an extent that it did not print out the results in a readable form. The proportion of gross errors was also large with the printer. Owing to these, the mean absolute deviation grew higher than with other equipment measuring direct observed times. On the other hand, it produced less 5/10 errors by reading out results than were to be found in the results of other equipment.

In watches with pointer display the measuring accuracy, according to Table 4 , was, with the normal way of recording, clearly better with watches with split action in which the pointer could be stopped before the read out at the break point (watches 3,4 and 6 ), than with normal type watches (5 and 7) in which the result had to be read out while the pointer was moving. In these watches the pointer could be stopped blindly by pressing a button. The investigator could therefore observe with his eyes the job throughout the pro- 
Table 4. Measuring accuracy of time study equipment in normally recorded results of basic material.

\begin{tabular}{|c|c|c|c|c|c|c|}
\hline \multirow[b]{2}{*}{ Equipment ${ }^{\mathbf{1}}$ ) } & \multicolumn{2}{|c|}{ Total material } & \multicolumn{2}{|c|}{ (37 548 observ.) } & \multicolumn{2}{|c|}{ Measured times (36876 observ.) } \\
\hline & $\begin{array}{c}\text { Missing } \\
\text { times } \\
\%\end{array}$ & $\begin{array}{c}5 / 10- \\
\text { errors } \\
\%\end{array}$ & $\begin{array}{c}\text { Gross } \\
\text { errors } \\
\%\end{array}$ & $\begin{array}{c}\text { Faultless } \\
\text { results } \\
\%\end{array}$ & $\begin{array}{l}\text { Abs. meas. err. } \\
\bar{x} \mathrm{cmin} / \text { measur. }\end{array}$ & $\begin{array}{l}\text { Abs. deviation } \\
\overline{\mathrm{x}} \mathrm{cmin} / \text { measur. }\end{array}$ \\
\hline 1. Printer .................... & 3.75 & 1.20 & 1.17 & 63.33 & 0.19 & 1.01 \\
\hline 2. Digital watch ............. & 2.12 & 1.35 & 0.36 & 69.40 & -0.00 & 0.71 \\
\hline 3. 3 watch board ........... & 1.81 & 1.56 & 0.22 & 72.20 & 0.04 & 0.67 \\
\hline 4. Taylor-watch .............. & 0.97 & 1.86 & 0.22 & 64.87 & -0.33 & 0.75 \\
\hline 5. Normal stop watch ... & 1.24 & 1.45 & 0.24 & 48.88 & -0.62 & 0.90 \\
\hline $\begin{array}{l}\text { 6. Cum. timing, watch ... } \\
\text { with split action } \ldots \ldots . .\end{array}$ & 1.45 & 2.65 & 0.88 & 64.49 & $\begin{array}{c}0.10 \\
\left.(-0.02)^{2}\right)\end{array}$ & $\begin{array}{l}1.04 \\
\left.(0.90)^{2}\right)\end{array}$ \\
\hline $\begin{array}{l}\text { 7. Cum. timing, normal . } \\
\text { stop watch }\end{array}$ & 2.15 & 2.40 & 1.28 & 62.55 & $\begin{array}{c}0.13 \\
\left.(-0.08)^{2}\right)\end{array}$ & $\begin{array}{l}1.26 \\
\left.(1.03)^{2}\right)\end{array}$ \\
\hline 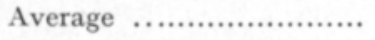 & 1.79 & 1.72 & 0.50 & 64.06 & -0.12 & 0.85 \\
\hline 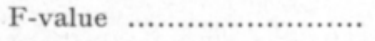 & 21.07 & 7.88 & 18.44 & 155.55 & 44.75 & 18.87 \\
\hline 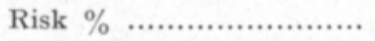 & 0.00 & 0.00 & 0.00 & 0.00 & 0.00 & 0.00 \\
\hline
\end{tabular}

1) Significance of differences is explained in Table 5.

${ }^{2}$ ) Value cleared from errors caused by missing times to subsequent times.

Table 5. The significance of the differences between the equipment presented in Table 4 with $5 \%$ risk. Nonsignificant differences are underlined.

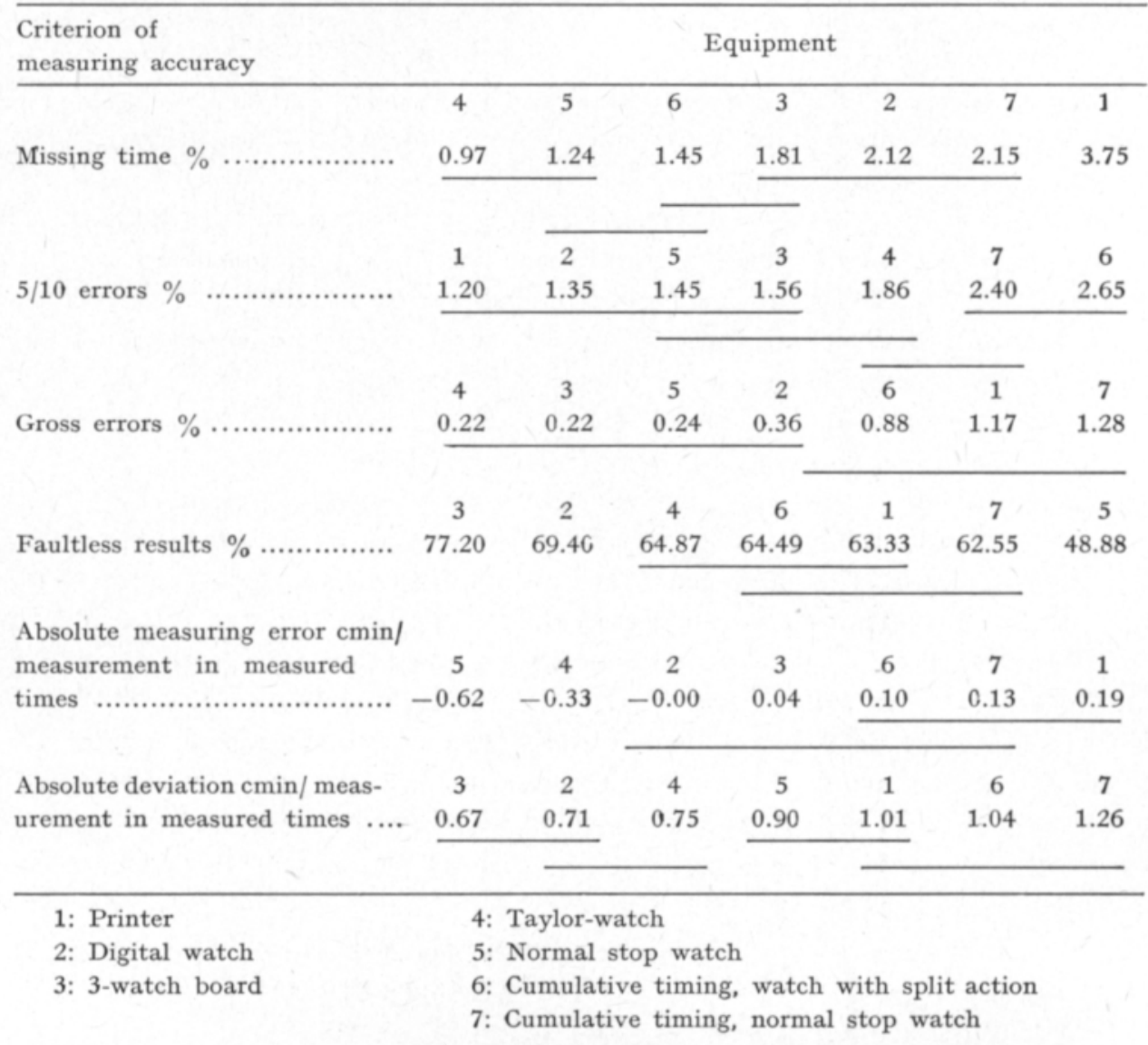


cess and transfer his attention to reading the result after the break point. In the use of normal type watches it would be necessary to observe the work and to read out the result simultaneously, which, according to SäLLForS (1945, p. 172) is difficult in particular in fly-back timing. In fact, in this study the normal stop watch gave clearly the lowest proportion of faultless results, below $50 \%$.

The results read out from watches with pointer display have to be transformed into figures corresponding to the position of the pointer on the scale. In this transformation phase errors are liable to occur (e.g. RoHMERT, ref. KraUse 1962, HäKKInen 1970). Consequently, equipment with digital display generally lead to less errors than do corresponding watch types equipped with analog display.

Contrary to advance expectations based on information in the literature, the digital watch (No. 2) used in the study proved in a normal recording (Table 4) only equal to the best watches with pointer display. In both these types the pointer or time counter may be stopped at break point. The result is probably not a mere random deviation from the general line since also HAMMER and AL-NAwam (1973) have obtained almost corresponding results in their studies with instruments of the same type. The result may be explained by the fact that in normal watches the designs of scales and pointers are highly finished as a result of a lengthy development period, while in the digital watch,which is a new type, all the possible factors producing read out errors have apparently not yet been taken into consideration.

Judging by the results, the question of whether results have to be produced in an analog or digital form, seems of secondary importance. What seems to be important, however, is that the time study equipment can be stopped blindly at break point to display the time at that moment, and that the result may be read out and written down after the break point.

The absolute measuring error calculated from the measured times and shown in Table 4 illustrates the systematic error that occurs in the use of the equipment. It may be due to a faulty regulating of the watch or to the fact that the result has been systematically wrongly read out. The systematic error is specially clear in the results of a normal stop watch with fly-back timing. The error mav be chiefly due to the fact that when the time has been read out some of the results have not been rounded up. Likewise, if the watch is held and observed diagonally, this may give a so-called parallaxial error in results of a certain magnitude as already noted (p. 28). The erıor caused by the wrong running speed of the watch is generally rather unimportant especially in the measuring of short times. In a well regulated stop watch the error caused by speed synchronization may be even below $0.1 \ldots 0.3 \%$ (Heuer 1961, Pechiold 1964).

The measuring accuracy in punching was clearly poorer than when the result was normally written down. This is at least partly due to the fact that the test persons were not trained to record the results with a punchnig stick on prepunched cards so well as in the use of pencil and paper. Even if the training differences are taken into account it seems that punching as a recording method is suitable only when the test persons have been well trained in the 
use of this method and the elements are sufficiently long. At the training level of the test persons the element times should be at least $40 \ldots 80 \mathrm{cmin}$ (PEHKONEN 1973).

Table 6. Measuring accuracy of time study equipment in punched results of basic material.

\begin{tabular}{|c|c|c|c|c|c|c|}
\hline \multirow[b]{2}{*}{ Equipment ${ }^{1}$ ) } & \multicolumn{4}{|c|}{ Total material (1 707 observ.) } & \multirow{2}{*}{$\begin{array}{l}\text { Measured times } \\
\text { Abs. meas. err. } \\
\overline{\mathrm{x}} \mathrm{cmin} / \text { measur. }\end{array}$} & \multirow{2}{*}{$\begin{array}{l}\text { (1 } 478 \text { observ. }) \\
\text { Abs. deviation } \\
\overline{\mathrm{x}} \mathrm{cmin} / \text { measur }\end{array}$} \\
\hline & $\begin{array}{c}\text { Missing } \\
\text { times } \\
\%\end{array}$ & $\begin{array}{c}5 / 10- \\
\text { errors } \\
\quad \% \\
\end{array}$ & $\begin{array}{c}\text { Gross } \\
\text { errors } \\
\%\end{array}$ & $\begin{array}{c}\text { Faultless } \\
\text { results } \\
\%\end{array}$ & & \\
\hline 2. Digital watch ............ & 22.56 & 5.26 & 3.38 & 42.48 & 0.69 & 2.29 \\
\hline 3. 3 watch board .......... & 7.65 & 7.39 & 1.85 & 52.77 & 0.22 & 1.86 \\
\hline 4. Taylor-watch .............. & 8.42 & 9.69 & 1.28 & 44.39 & -0.39 & 1.79 \\
\hline 5. Normal stop watch ... & 8.26 & 5.37 & 1.24 & 30.99 & -0.74 & 1.70 \\
\hline $\begin{array}{l}\text { 6. Cum. timing, watch ... } \\
\text { with split action ....... }\end{array}$ & 20.51 & 6.73 & 10.58 & 32.05 & $\begin{array}{c}4.58 \\
\left.(-0.48)^{1}\right)\end{array}$ & $\begin{array}{l}7.75 \\
\left.(1.85)^{1}\right)\end{array}$ \\
\hline $\begin{array}{l}\text { 7. Cum. timing, normal } \\
\text { stop watch }\end{array}$ & 19.83 & 7.76 & 12.93 & 22.41 & $\begin{array}{c}2.91 \\
\left.(-0.34)^{1}\right)\end{array}$ & $\begin{array}{l}6.75 \\
\left.(2.97)^{1}\right)\end{array}$ \\
\hline Average...$\ldots \ldots \ldots \ldots \ldots \ldots$ & 13.42 & 7.21 & 4.22 & 40.30 & 0.89 & 3.17 \\
\hline F-value $\ldots \ldots \ldots \ldots \ldots \ldots \ldots$ & 12.73 & 1.31 & 15.08 & 12.55 & 8.94 & 16.20 \\
\hline Risk $\% \quad \ldots \ldots \ldots \ldots \ldots \ldots \ldots$ & 0.00 & 25.88 & 0.00 & 0.00 & 0.00 & 0.00 \\
\hline
\end{tabular}

1) Value cleared from errors caused by missing times to subsequent times.

Judging by Table 6 the various kinds of equipment differ in their suitability for the punching method. The proportion of missing times is about $20 \%$ with the digital watch and with both the watches used with the cumulative timing method, while it is below $10 \%$ with the other watches. In the cumulative timing method the punching of the additional number of figures $(1 \ldots 2)$ has had an adverse effect on the measuring accuracy. It is not always possible to manage only with one hand the operation keys of the digital watch like in other watches, which makes its use, especially in the punching method, more difficult. In the use of the digital watch Hammer and Al-Nawam (1973) noted a similar reaction when results were written down normally and when the times were very short, on an average about $5 \mathrm{cmin}$. The recording of the measuring result by punching took more time and entailed a higher degree of concentration in the test persons than did normal writing down with pencil on paper. In this way the actual observing of times was given less attention in the punching method than in the normal one. Results recorded by punching thus serve to give information on how suitable the different kinds of instruments are in measuring situations in which a large part of the attention of the investigator has to be given to matters other than the actual timing.

The occurrence of different errors in the use of time study equipment does not depend solely on the equipment itself, since the way it is put to use plays a decisive part. In the normally recorded results of the basic material the influence of the test person has been clearly of foremost importance to 
the accuracy of the results obtained with the printer (Table 7). With the use of a digital watch the effect of the test person was likewise clear. Prior to the study the test persons had only used various kinds of stop watches. They became trained in the use of the printer and the digital watch mainly in the course of the study (see p. 36), which is reflected in the measuring accuracy achieved with these instruments.

Table 7. Influence of test person on the accuracy of time study equipment.

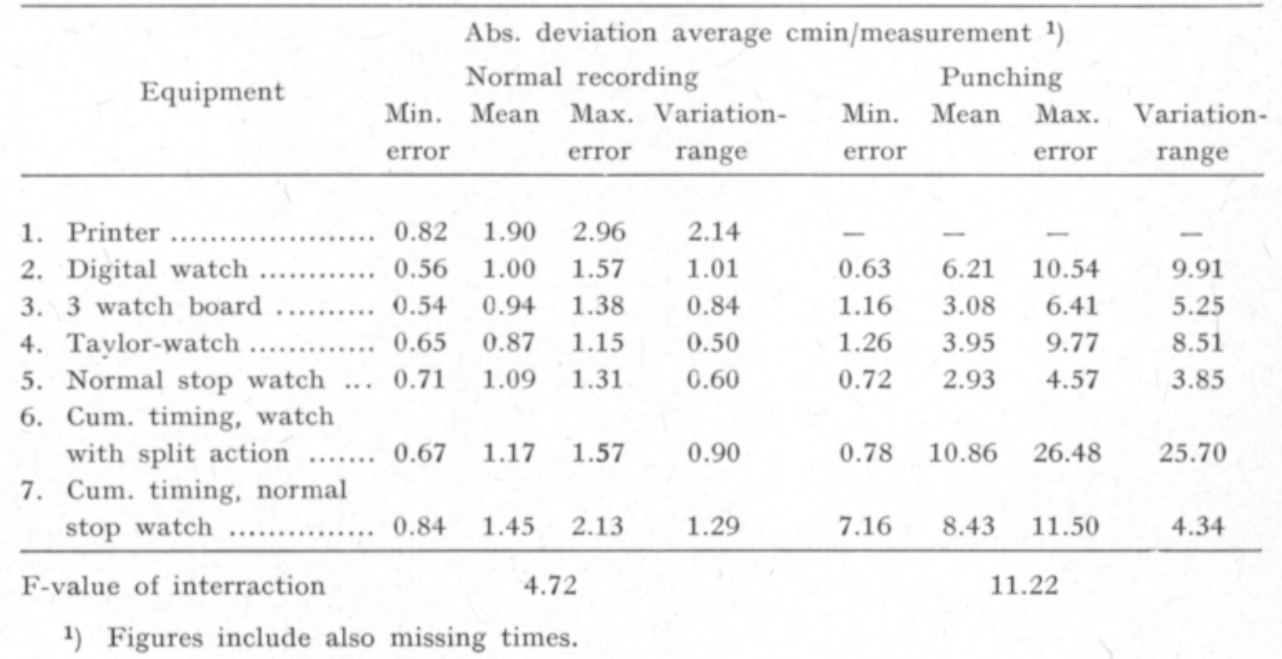

In a normal recording process the different test persons affected the measuring accuracy least of all when using stop watches with a fly-back system. In the punching method the stop watches with split action gave a clearly broader distribution in the measuring accuracy than did corresponding normal stop watches. Judging by the results, simpler construction and/or smaller possibilities of misuse of the equipment reduced also the effect of the investigator on the accuracy which can be obtained in the use of the equipment.

The estimated overall effect on the measuring accuracy of the different time study instruments was found to be small. The differences in the equipment explain in normal recordings from the total variation of the absolute deviation about $0.5 \%$, and in punching about $5.9 \%$. The choice of equipment does have an effect in practice, however, as it is generally an easy way of influencing the measuring accuracy.

\section{The test persons}

As noted preliminarily in the preceding chapter, the test persons did affect the measuring accuracy. The influence of the eight test persons of the basic material on the various criteria of the measuring accuracy is shown in Table 8 . 
The differences between the persons were specially great in punched results in general, and particularly so when the proportion of missing times is used as criterion. In the examination of the results it should be taken into account that the same person was not the best or the worst by all the different criteria. For example, in the punched results the person with the largest proportion of missing times had the smallest proportion of $5 / 10$ errors. The differences between the test persons have been examined in greater detail in the results of the first part of the study (PEHKONEN 1973).

Table 8. Variations in mean accuracy between test persons in basic material.

\begin{tabular}{|c|c|c|c|c|c|c|}
\hline \multirow[b]{2}{*}{ Criteria of accuracy } & \multicolumn{2}{|c|}{ Normally recorded } & \multirow{2}{*}{$\begin{array}{c}\text { results } \\
\text { Max. } \\
\text { error }\end{array}$} & \multicolumn{3}{|c|}{ Punched results } \\
\hline & $\begin{array}{l}\text { Min. } \\
\text { error }\end{array}$ & Mean & & $\begin{array}{l}\text { Min. } \\
\text { error }\end{array}$ & Mean & $\begin{array}{l}\text { Max. } \\
\text { error }\end{array}$ \\
\hline \multicolumn{7}{|l|}{ Total material } \\
\hline Missing times $\%$..................... & 0.69 & 1.79 & 2.96 & 3.80 & 13.42 & 34.38 \\
\hline 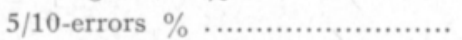 & 1.16 & 1.72 & 2.53 & 2.34 & 7.21 & 9.95 \\
\hline Gross errors $\%$....................... & 0.37 & 0.50 & 0.88 & 0.35 & 4.22 & 8.60 \\
\hline Faultless results $\%$.................... & 68.16 & 64.06 & 58.67 & 53.59 & 40.30 & 26.59 \\
\hline \multicolumn{7}{|l|}{ Measured times } \\
\hline $\begin{array}{l}\text { Abs. measuring error } \overline{\mathrm{x}} \mathrm{cmin} / \\
\text { measurement } \ldots \ldots \ldots \ldots \ldots \ldots \ldots\end{array}$ & -0.05 & -0.12 & -0.15 & -0.10 & 0.89 & 4.48 \\
\hline $\begin{array}{l}\text { Abs. deviation } \overline{\mathbf{x}} \text { cmin/ } \\
\text { measurement } \ldots \ldots \ldots \ldots \ldots \ldots \ldots\end{array}$ & 0.78 & 0.85 & 1.02 & 1.21 & 3.17 & 8.21 \\
\hline
\end{tabular}

The, measuring accuracy of all the test persons in the basic material improved as the study progressed, due, no doubt, to increasing training and its effect on the measuring accuracy. The correlation coefficient between the absolute deviation and the variable, which indicates in how many measuring series the test person had used specified time study equipment was $-0.034 * * *$ in normally recorded results and $-0.133^{* * *}$ in punched results. The effect of training on the occurrence of different kinds of qualitative errors did not prove to be consistent, however.

The differences between the test persons in the basic material are due, apart from actual differences in the suitability of the persons for time study, also to the fact that some of them learnt and trained themselves to use the tested equipment more quickly than others. Viewed as a whole, although there are clear differences in the measuring accuracies of the test persons, they explain only $0.2 \%$ of the total variation of the absolute deviation in normally recorded results and $6.4 \%$ in the punched results.

Since the measuring accuracy was only slightly affected also by other factors defined in the basic material, as has already been stated, the major part of the variation in the measuring accuracy is caused by factors not defined in the study. Among these the most important factor group may be considered the internal variation of the measuring accuracy of the test persons (РЕнко- 
NEN 1973). The effect of these human factors was further investigated by collecting a new so-called human factors material.

In the human factors material there were likewise significant differences in measuring accuracy between the different test persons. The differences explain in this material clearly a larger part (about $8 \%$ ) of the total variations in the measuring accuracy than in the corresponding normally recorded results of the basic material. In a total of 14 test persons $(7.9 \%)$ the mean absolute deviation remained below 0.5 cmin per measurement (PEHKONEN 1975).

\section{Factors affecting time measuring ability}

In the human factors material certain variables applying to specific test persons and their characteristics were examined (Penkonen 1975). On the basis of these variables it was hoped to single out the most important factors affecting the measuring accuracy and to determine the power of their influence.

3311. Age and sex

The age of test persons is clearly correlated with the measuring accuracy $\left(\mathrm{r}=0.078^{* * *}\right)$. Calculated by age category the absolute deviation was as follows:

$\begin{array}{lll}19 \ldots 22 \text { years } & 1.14 \mathrm{cmin} \text { per measurement } \\ 23 \ldots 27-0 & 0.86 & - \\ 28 \ldots 32-- & 1.05 & - \\ 33 \ldots 37-- & 1.32 & - \\ 38 \ldots 42-- & 1.35 & - \\ 43 \ldots 57-\ldots- & 1.40 & -\end{array}$

Test persons aged around 25 years possessed the best measuring accuracy, which deteriorated clearly with age up to about 35 years. The differences between the age categories are not, however, caused merely by physiological changes brought about by age which affect the timing, such as possible deterioration of sight etc., other factors, likewise, accompany the differences in age in the material. Age correlates with a number of independent variables so that in this connection it describes other facts in addition to the mere age of the test person (PEHKONEN 1975).

It was clear that less time had passed since the young test persons had finished their school studies or other training courses as compared to the older ones, in other words the learning of new facts in the form of courses was for them a more familiar process. RuBEnowitz (1971, p. 186) presents in his book a similar point of view. Young persons learnt to use time study techniques during the courses evidently somewhat quicker than older persons. The youngest age category, a total of 9 test persons, is a clear exception, however, apparently because of their slight practical experience and low level of training. It seems to be clear that with increased experience and training, the influence of the age difference on measuring accuracy decreases.

Among the test persons the women, a total of 22 persons, measured the times with clearly better accuracy than the men, a total of 155 persons. According to GHISELLI and Brown (1969, p. 89), in certain professions persons of one 
sex may be more skilled than those of the opposite sex. The difference in sex noted in this study may not directly be taken as a general fact since the sex groups differ from each other also in other respects. Judging by the results it seems clear, however, that in the early stages of training young women are more suitable for time study than older men.

\section{Education}

The measuring accuracy of the test persons was affected by their basic as well as their professional education. With a higher level of the basic schooling the measuring accuracy, expressed in absolute deviation, improved as follows:

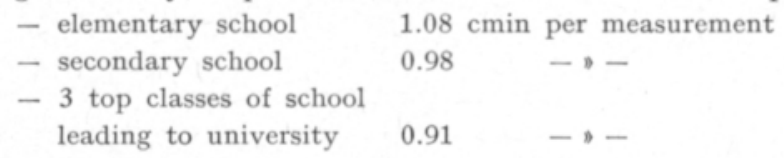

As the basic schooling level in the material is dependent on several other variables (PEHKonen 1975), the result in practice is not as unambiguous as it may seem in the light of the above figures.

Persons with university degrees and persons without any vocational training showed a clearly higher degree of measuring accuracy compared to persons who had had vocational training on a school or institutional level (PEHKonen 1975). The high level of measuring accuracy of persons without vocational training may be explained by the fact that they attended the course expressly in order to be trained as work study people. Their motivation was therefore obvious and they evidently tried their best in the study which was at the same time the test in the use of a stop watch in each course.

The positive dependence between the basic level schooling and the measuring accuracy accords well with the results presented, among others, by RUBENOWITZ (1971, p. 82), according to which increased education contributes to an improved ability to learn new things. What seems essential in the relation between vocational training and measuring accuracy is not its level but the orientation, which is not indicated by the presented levels. The influence of the vocational training level may, however, in this connection be combined with what RUBENOWITZ (1971, p. 177) referes to as a possible excessive evaluation of one's own abilities and skills at a certain level of training. It is possible that some of the persons with an institutional or vocational schooling have considered the test in the use of the stop watch as being so easy that they have not concentrated on the timing in the best possible way. This opinion is supported by the estimates of the corresponding test person groups regarding their own level of training.

\section{Familiarity with work studies}

When the profession preceding the course was closely connected with the work study, the measuring accuracy of the test persons was clearly above average (PehKonen 1975). When the profession is closely related to work study, it improves also the level of training for time studies, which was estimated by each test person himself (correlation coefficient $+0.40^{* * *}$ ). Practical knowledge acquired prior to the course in actual work study served to improve 
almost directly the accuracy in timing. It should be noted in particular that those with the longest period of practice (at least 3 years) carried out the rounding up sufficiently often. In the measured times the absolute measuring error was in their results on the average $0.00 \mathrm{cmin}$ per measurement while with other persons it was clearly negative. The distribution of their results was also broad, which in the light of the results presented by PECHHOLD (1964) is not a sign of a high level of training, however.

In judging the result it should be noted that the time spent in work studies is not the same thing as training in the performing of time studies. There are, after all, many different kinds of work studies and the share of time studies in these varies with different persons. In the study material the correlation coefficient between the time spent on work studies and the level of training based on the personal estimate of the test person was $+0.39^{* * *}$.

Table 9. Average measuring accuracy in different levels of training.

\begin{tabular}{|c|c|c|c|c|}
\hline $\begin{array}{l}\text { Level of training to } \\
\text { perform time studies }\end{array}$ & $\begin{array}{c}\text { Deviation } \\
\overline{\mathrm{x}} \mathrm{cmin} / \text { measur. }\end{array}$ & $\begin{array}{l}\text { Measuring error } \\
\text { in measured } \\
\text { times } \\
\overline{\mathrm{x}} \mathrm{cmin} / \text { measur. }\end{array}$ & $\begin{array}{c}\text { Missing times } \\
\%\end{array}$ & $\begin{array}{l}\text { Number of } \\
\text { test persons }\end{array}$ \\
\hline 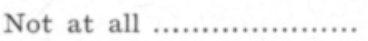 & 1.10 & -0.36 & 2.6 & 55 \\
\hline Fairly good $\ldots \ldots \ldots \ldots \ldots \ldots \ldots$ & 1.09 & -0.25 & 2.9 & 108 \\
\hline Almost perfect ............... & 0.64 & -0.09 & 0.5 & 13 \\
\hline Perfect .......................... & 0.97 & +0.10 & 4.7 & 1 \\
\hline F-value $\ldots \ldots \ldots \ldots \ldots \ldots \ldots$ & 30.51 & 25.73 & & \\
\hline
\end{tabular}

The test person's level of training, based on the personal estimate of each person, did, according to Table 9 , have a relatively clear effect on the measuring accuracy. Increase in training improves the measuring accuracy, which tallies with the results presented by PECHHOLD (1964). Since each person estimates his own level of training it is clear that persons on the same level of training have placed themselves in different ways in the categories indicated in Table 9. Judging by the results, the selection between the categories not at all or fairly good has been made in a random fashion.

3314. Intelligence and techno-mechanical talent

The tests in question had not been planned expressly for the measuring of suitability to time studies, nor was the test a complete ability test as it was only a minor one lasting about one hour. The variables based on the test results, intelligence and techno-mechanical talent, were designed to describe certain characteristics of the test persons. The names of talents used in this connection, e.g. general intelligence, may be ambiguous, however, which, according to RUBE NOWITZ (1971, p. 65), is relatively common in situations of this kind.

The number of different qualitative errors seems to have a certain dependence on the characteristics revealed by the intelligence test. The number of 
points in the intelligence test (scale $0 \ldots 9$ ) was in the measured times on an average $\mathbf{5 . 0 8}$ and in the missing times 4.78. In this respect a techno-mechanical talent made no difference. A corresponding situation prevailed in regard to the $\mathbf{5} / \mathbf{1 0}$ errors and the gross errors.

The effect on the quantitative measuring accuracy of the characteristics described by the test results is shown in Fig. 8 in the test points divided into magnitude of error categories. When the absolute deviation does not exceed $0,6 \mathrm{cmin}$ per measurement, the intelligence test shows clearly the highest number of points. The number of points declines degressively with the increase in the error except in the largest category of errors. As regards techno-mechanical talent, the result is not equally clear cut. Owing to the large number of observations in the first two categories of error, their effect on the total results is decisive. This is apperent, among other things, in the positive, even if not statistically significant, correlation between the test result and the absolute deviation $(r=0.007)$ and it is reflected also in the results of the regression analysis.

Figure 8. Average number of test points in separate error categories.

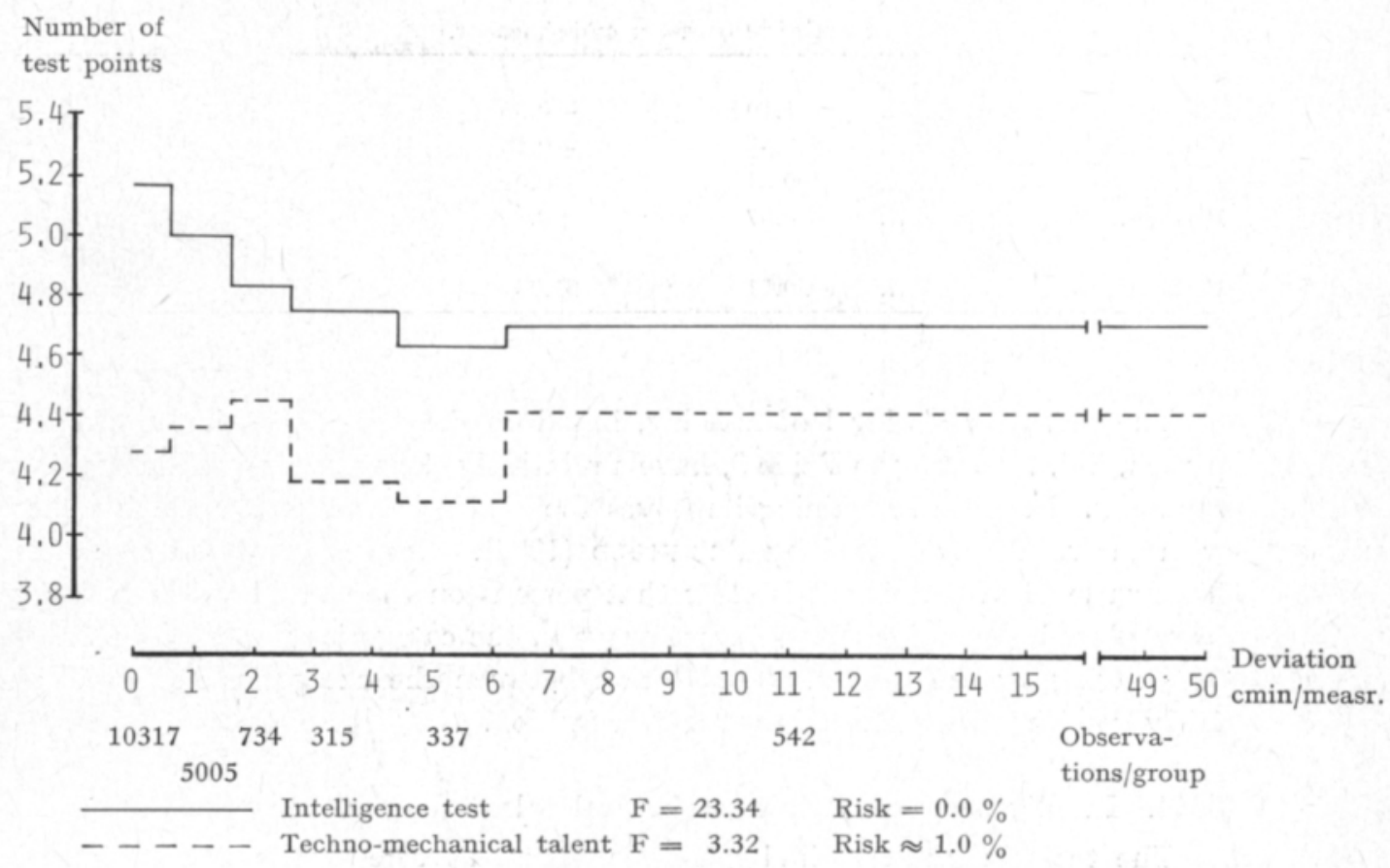

Among the test results the characteristics indicated by the intelligence test, primarily the so-called general intelligence, seem to have the most pronounced influence on the measuring accuracy. In general, intelligence tests are supposed to be useful for the measuring of certain skills required in working life, such as ability to learn and productivity (GHISELli and Brown 1969, p. 229). According to Rubenowitz (1971, p. 71), so-called general intelligence 
contributes to success in all work that requires of the person in question some kind of aptitude.

The dependence between the number of points in the intelligence test and the measuring accuracy established in the results, conforms with the general proposed line. There are, however, so many exceptions to this line that a person's timing ability can not be reliably estimated merely on the basis of the number of test points.

Although several of the variables describing the test persons and their characteristics had a statistically significant effect on the measuring accuracy, none of them alone go very far in explaining the total variation in the measuring accuracy. Not much information may thus be gained on the basis of this kind of characteristic regarding the accuracy attained by a specific person in a timing phase.

\section{Compressing the information}

The preceding tabulation phase has dealt with the effect of different factors on measuring accuracy. On the basis of the results thus obtained it is, however, difficult to form a total picture of the factors that simultaneously affect the measuring accuracy. As stated earlier (p. 23), for a total picture the results have been compressed with a factor analysis, which has been performed on the basic as well as the human factors material.

In accordance with the approximate estimate referred to by SänKIAHO (1974, p. 15), the rotation has included all factors with eigenvalues above 1.0. Corresponding explanations and an appropriate theoretical model of errors have not been available in the interpretation of the factors and so the interpretation has had to be done in another way. It is based on variables obtaining the greatest loadings in the factors and their effects based on the tabulation stage. According to SänкiaHo (1974, p. 18), this kind of interpreting method is not to be recommended. It has, however, not been possible to use the above methods recommended by him in this connection. The success of the interpretation has been checked by counting the factor points and their means in the different categories of variables that are considered the most important ones as regards the factors.

In the basic material the analysis was performed separately for the punched as well as the normally recorded results, Since both factor solutions closely resemble each other in regard to their factors and loadings, only the results of the normal recording will be presented here. This part material contained clearly more variables affecting the measuring accuracy than did the punching method.

In the analysis performed on the normally recorded results the basic material gave 7 factors possessing an eigenvalue of over 1.0. After a varimax rotation (Table 10) they were interpreted as follows:

1. From the point of view of variables affecting measuring accuracy the factor may be considered as involving increased training during the study, in short it may be regarded as the training factor: 
2. The factor is connected with the variables showing the reading of a moving pointer and the use of a normal stop watch with fly-back method and in the opposite direction also with the reading of a stopped pointer. The factor thus describes primarily the use of a fly-back timing without split action and may thus be called the normal stop watch factor.

3. The factor describes in the first place different kinds of nonsystematic errors, which have been found to be due mainly to human factors, it may, therefore, be called the human measuring errors factor.

4. The factor indicates the technical construction of the time study equipment and its effect on the ease or difficulty of its use. Taking in consideration the directions of the loadings it may be regarded as the factor indicating the complications in the construction and/or use of the equipment.

5. The high loadings of the factor are connected with the variables which indicate, in addition to their main content, the distances of the test persons from the light panel. From the point of view of measuring accuracy it indicates how difficult it is each time to notice the break point, and so it may be called the break point factor.

6. The factor describes primarily the systematic error indicated in the error theory. Through missing times it indicates a strong human factor so that in its factual content it comes close to factor No. 3. To distinguish it from this factor it may be called the factor of missing times and systematic errors.

7. The factor describes relatively unambiguously time study performed according to the cumulative timing method. It may, therefore, be called the cumulative timing method factor.

When examining the above structure of factors, which includes both independent as well as dependent variables, certain dependencies should be noted. The variables used as criteria of measuring accuracy are closely connected with factors 3 and 6 and only loosely with the other factors. The linear regression model, in which the various criteria of the measuring accuracy were the independent variables and the corresponding factor points were the dependent ones, explained in factors 3 and 6 about $99.5 \%$ of the variance and in the rest only $0.2 \ldots 2.7 \%$. Since the major part of the deviations in the measuring accuracy is based on the varying measuring accuracy of the test persons at different times, it is justifiable, irrespective of technical dependence, to add the factual contents of the factors 3 and 6 to the measuring errors caused by human factors.

The dependencies between the training factor (No. 1) and the variables describing quantitatively the measuring accuracy are according to expectation as regards direction, but low as regards their power. The variables indicating the involvement of various kinds of errors have loadings in both directions, on the other hand.

The dependence between the use of a normal stop watch (factor 2) and the share of faultless results is clearly negative. The complications of the construction and the use of time study equipment (factor 4), implying primarily the printer and the digital watch, is in a negative although low dependence to the 
Table 10. Factor solution from normally recorded results of basic material.

\begin{tabular}{|c|c|c|c|c|c|c|c|c|}
\hline \multirow{2}{*}{ Variable } & \multicolumn{8}{|c|}{ Factors } \\
\hline & 1 & 2 & 3 & 4 & 5 & 6 & 7 & $\mathrm{~h}^{2}$ \\
\hline No. of test & 0.776 & -0.020 & 0.009 & 0.066 & 0.367 & 0.042 & -0.104 & 0.755 \\
\hline No. of replication ................. & -0.048 & -0.012 & -0.004 & -0.035 & -0.107 & -0.016 & 0.030 & 0.016 \\
\hline 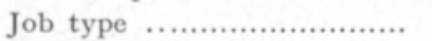 & C. 258 & 0.015 & -0.018 & 0.003 & 0.134 & 0.010 & 0.070 & .090 \\
\hline Absolute measuring error .... & -0.009 & 0.025 & -0.086 & -0.002 & -0.028 & 0.855 & 0.029 & 0.740 \\
\hline Absolute deviation ............... & -0.005 & 0.016 & 0.843 & 0.053 & 0.027 & -0.220 & -0.011 & 0.763 \\
\hline Element code error $. . . \ldots \ldots \ldots . .$. & -0.014 & 0.010 & 0.153 & 0.019 & -0.012 & -0.130 & 0.011 & 0.041 \\
\hline Master value ..................... & 0.060 & 0.037 & -0.083 & 0.060 & 0.070 & -0.017 & 0.027 & 0.021 \\
\hline Missing time...$\ldots \ldots \ldots \ldots \ldots \ldots \ldots \ldots \ldots \ldots \ldots$ & -0.005 & 0.022 & 0.426 & 0.039 & 0.005 & -0.574 & -0.017 & 0.514 \\
\hline Proportional measuring error & 0.002 & 0.038 & 0.120 & 0.011 & -0.010 & 0.861 & 0.019 & 0.758 \\
\hline Proportional deviation ......... & -0.001 & 0.010 & 0.880 & 0.018 & 0.006 & -0.016 & -0.605 & 0.776 \\
\hline $5 / 10$ error $\ldots \ldots \ldots \ldots \ldots \ldots \ldots \ldots \ldots \ldots \ldots \ldots \ldots$ & 0.014 & -0.000 & 0.164 & -0.026 & C.004 & 0.606 & 0.024 & 0.028 \\
\hline Gross error ...................... & -0.011 & 0.019 & 0.629 & 6.043 & -0.003 & 0.292 & 0.006 & 0.483 \\
\hline Faultless result $\ldots \ldots \ldots \ldots \ldots \ldots \ldots . . . .$. & -0.026 & 0.138 & -0.327 & 0.035 & -0.072 & 0.117 & 0.008 & 0.147 \\
\hline No disturbance .................. & -0.826 & -0.017 & 0.020 & $-c .079$ & 0.170 & -0.017 & -0.015 & 0.718 \\
\hline Noisy conditions $. . . \ldots \ldots \ldots \ldots . . . .$. & 0.489 & -0.034 & 0.015 & 0.011 & -0.088 & 0.023 & -0.013 & 0.249 \\
\hline 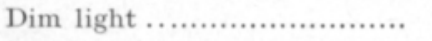 & 0.466 & 0.001 & -0.033 & 0.058 & -0.143 & -0.010 & 0.079 & 0.249 \\
\hline Dim light \& noisy cond. ...... & 0.363 & 0.678 & -0.014 & 0.063 & -0.021 & 0.018 & -0.066 & 0.147 \\
\hline Coldness ......................... & 0.098 & 0.021 & -0.011 & 0.029 & 0.544 & 0.002 & -0.018 & 0.307 \\
\hline Hearing isolation ................. & 0.036 & -0.034 & 0.017 & -0.066 & -0.926 & -0.012 & 0.057 & C. 868 \\
\hline Distance of isolation ............. & -6.124 & 0.026 & -0.012 & 0.060 & 0.688 & 0.014 & -0.062 & 0.497 \\
\hline Alarm before break point ..... & -0.038 & -0.001 & -0.033 & 0.053 & -0.056 & 0.013 & -0.026 & 0.009 \\
\hline Type of equipment .............. & -0.072 & -0.110 & 0.006 & -0.951 & -0.082 & 0.020 & 0.118 & 942 \\
\hline Moving pointer .................. & -0.083 & -0.943 & 0.037 & -0.174 & -0.021 & -0.003 & 0.051 & 0.931 \\
\hline Stopped pointer $\quad \ldots \ldots \ldots \ldots \ldots . . . .$. & 0.016 & 0.641 & -0.010 & -0.607 & -0.034 & 0.007 & 0.110 & 0.793 \\
\hline Cumulative timing $\ldots \ldots \ldots \ldots \ldots . .$. & -0.100 & -0.051 & 0.056 & -0.145 & -0.093 & 0.018 & 0.926 & 0.903 \\
\hline Printer ............................. & 0.068 & 0.088 & 0.024 & 0.741 & 0.095 & -0.041 & 0.003 & 0.573 \\
\hline Digital watch .................... & 0.020 & 0.043 & -0.042 & 0.420 & 0.004 & 0.023 & -0.181 & 0.213 \\
\hline 3-watch board .................. & 0.024 & 0.319 & -0.015 & -0.322 & 0.026 & 0.020 & -0.224 & 0.257 \\
\hline 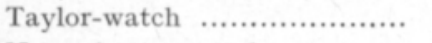 & 0.010 & 0.305 & -0.022 & -0.306 & 0.001 & -0.011 & -0.215 & 0.233 \\
\hline Normal stop watch ............. & 0.008 & -0.799 & 0.007 & -0.194 & 0.004 & -0.025 & -0.238 & 6.733 \\
\hline Cumulative timing, watch with & & & & & & & & \\
\hline $\begin{array}{l}\text { split action } \ldots \ldots \ldots \ldots \ldots \ldots \ldots \ldots \\
\text { Cumulative timing, normal }\end{array}$ & -0.005 & 0.237 & 0.027 & -0.167 & -0.079 & -0.002 & 0.769 & 0.683 \\
\hline 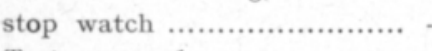 & -0.149 & -0.368 & 0.050 & -0.008 & -0.047 & C.029 & 0.395 & 0.319 \\
\hline Test person 1 .................... & -0.193 & -0.016 & -0.019 & -0.006 & -0.050 & 0.009 & 0.035 & 0.042 \\
\hline Test person $2 \ldots .$. & 0.619 & -0.038 & 0.017 & 0.004 & 0.054 & -0.012 & 0.001 & 0.005 \\
\hline Test person $3 \ldots \ldots \ldots \ldots \ldots \ldots \ldots . . . . . . .$. & 0.665 & -0.001 & -0.021 & 0.023 & 0.065 & 0.014 & -0.011 & 0.010 \\
\hline Test person 4 ................... & 0.073 & 0.006 & 0.022 & -0.018 & 0.022 & -0.026 & 0.003 & 0.007 \\
\hline Test person 5 ....................... & 0.058 & -0.006 & -0.030 & -0.037 & 0.037 & 0.020 & 0.024 & 0.008 \\
\hline Test person $6 \ldots \ldots \ldots \ldots \ldots \ldots \ldots \ldots . . . . . . .$. & -0.199 & 0.029 & G.e15 & -0.002 & -0.008 & -0.004 & 0.010 & 0.041 \\
\hline Test person $7 \ldots \ldots \ldots \ldots \ldots \ldots \ldots . . . . . . . .$. & 0.066 & 0.017 & 0.028 & -0.005 & 0.007 & -0.019 & -0.048 & 0.008 \\
\hline Test person $8 \ldots \ldots \ldots \ldots \ldots \ldots \ldots . . . . . .$. & 0.003 & 0.009 & -0.018 & 0.046 & -0.159 & 0.024 & -0.002 & 0.028 \\
\hline Training to use specific equip. & 0.741 & 0.068 & -0.008 & -0.213 & 0.352 & 0.045 & -0.220 & 0.774 \\
\hline
\end{tabular}

Factors:

1. Training

2. Normal stop watch

3. Human measuring errors
4. Complication of equipment

5. Break point

6. Missing times and systematic errors

7. Cumulative timing method 
amount of 5/10 errors, in other words the use of this kind of equipment cuts down reading errors. Their use does, however, increase the share of gross errors.

The analysis performed on the human factors material gave also 7 factors with an eigenvalue of more than 1.0. They have been interpreted in the study report of the second part of the project (PEHKONEN 1975) and are presented in Table 11.

In the human factors material the age, sex and test results of the investigators are closely connected with familiarity with time studies (Table 11, factor 2). Consequently the way they are reflected in the results of the above tabulation stage may at least partly be explained by the differences in the degree of training. Familiarity as such, as well as training in the basic material, had a surprisingly limited effect on the amount of the quantitative errors and the number of qualitative errors. Among these it is most clearly connected with the proportion of the faultless results.

An interesting result was the clear negative dependence of the variables describing correspondence of simulation with normal work as study object, and the ease of timing in simulation on factor No. 3 describing the distance of the test persons from the light panel. Admittedly its effect on the occurrence of different errors was rather small. The time to be measured did not have a specially noticeable absolute effect on the measuring accuracy, the relative effect was obvious, however.

In the human factors material the information yielded by human nonsystematic errors (factor 5), which was the most interesting variable group, remained rather scanty. Among the variables describing the characteristics of the test persons, age and intelligence are more clearly than other variables connected with this kind of error.

In comparing the analyses performed from both part materials it is possible to find factors with features that are clearly common to both materials despite their subject matter differences:

- Nonsystematic errors due to human factors: factor 3 in the basic material and factors $\mathbf{5}$ and $\mathbf{7}$ in the human factors material.

- Systematic errors and missing times: factor 6 in the basic material and 1 in the human factors material. Together with the above factors these are closely connected in their information on measuring accuracy. The material composed of the means calculated on test persons, the so-called mean matrix, did not in fact give these two kinds of factors as normal observation matrixes. Instead they form part of the very same factor together with the variables describing the deviation in the measuring accuracy (PEHKONEN 1975).

- The factors connected with possibilities of observing the break point; in basic material factor No. 5 and in human factors material factor No. 3 .

- Factors No. 1 in the basic material and No. 2 in the human factors material, which indicate the degree of training of the test person or his experience in the performance of time studies.

Owing to the difference in the materials, the basic material could not give the so-called talent factor, and the human factors material could not give 
Table 11. Factor solution of human factors material.

\begin{tabular}{|c|c|c|c|c|c|c|c|c|}
\hline \multirow{2}{*}{ Variable } & \multicolumn{8}{|c|}{ Factors } \\
\hline & 1 & 2 & 3 & 4 & 5 & 6 & 7 & $\mathrm{~h}^{2}$ \\
\hline No. of test ....................... & 0.040 & -0.009 & -0.008 & 0.871 & 0.008 & 0.010 & 0.017 & 0.762 \\
\hline Size of test group ............... & 0.035 & 0.120 & 6.767 & 0.011 & -0.016 & -0.207 & -0.020 & 0.648 \\
\hline Position of test person...... & 0.026 & 0.191 & 0.678 & 0.611 & 0.004 & -0.172 & -0.006 & 0.527 \\
\hline Age $. . . . \ldots \ldots \ldots \ldots . . . . .$. & 0.045 & 0.275 & -0.151 & -0.009 & 0.076 & 0.069 & 0.014 & 0.111 \\
\hline Male ............................... & 6.018 & 0.366 & 0.069 & 0.001 & $0 . \mathrm{C} 01$ & -0.343 & 0.041 & 0.254 \\
\hline Basic schooling................ & -0.010 & -0.077 & -0.480 & 0.002 & $-0.0 \mathrm{C} 8$ & -0.045 & -0.032 & 0.240 \\
\hline Vocational training ................ & -0.022 & 0.286 & -0.566 & -0.001 & 0.025 & -0.635 & -0.001 & 0.404 \\
\hline Professional connection with & & & & & & & & \\
\hline work'study ................... & -0.038 & -0.777 & -0.029 & -0.010 & -0.028 & C.100 & 0.020 & 0.617 \\
\hline Previous work studies .......... & -0.050 & -0.716 & 0.007 & -0.014 & 0.010 & -0.044 & 0.048 & 0.519 \\
\hline Level of training in work study & -0.013 & -0.543 & -0.017 & -0.007 & $-\mathrm{C} .022$ & 0.020 & C.002 & 0.296 \\
\hline Simulation versus normal work & 0.035 & -0.005 & -0.180 & -0.004 & -0.012 & -0.046 & -0.018 & 0.036 \\
\hline Ease of simulation $\ldots \ldots \ldots \ldots . . .$. & -0.024 & 0.226 & -0.307 & -0.004 & $-\mathrm{C} .038$ & c.019 & -0.027 & 0.149 \\
\hline Intelligence...$\ldots \ldots \ldots \ldots \ldots \ldots \ldots \ldots \ldots \ldots \ldots$ & -0.009 & -0.091 & -0.047 & 0.003 & -0.050 & -0.713 & -0.029 & 0.522 \\
\hline Techno-mechanical talent ...... & 0.016 & 0.150 & 0.120 & 0.005 & -0.001 & -0.751 & -0.605 & $0.6 \mathrm{C} 0$ \\
\hline Handwriting................... & 0.014 & -0.262 & -0.102 & 0.003 & -0.012 & 0.045 & -0.036 & 0.083 \\
\hline Master value ..................... & 0.012 & 0.021 & -0.000 & -0.875 & -0.051 & -0.006 & -0.043 & 0.771 \\
\hline Cumulative master value ....... & 0.035 & 0.006 & 0.005 & 0.043 & 0.007 & -0.004 & 0.008 & 0.003 \\
\hline Absolute measuring error ...... & -0.941 & -0.059 & 0.634 & 0.039 & 0.013 & 0.022 & $-0.11 C$ & 0.904 \\
\hline Proportional measuring error & -0.933 & -0.052 & 0.042 & -0.023 & 0.178 & 0.010 & -0.140 & 0.928 \\
\hline Absolute deviation ................ & 0.579 & 0.024 & 0.013 & 0.019 & 0.748 & 0.605 & 0.211 & 0.939 \\
\hline Proportional deviation .......... & 0.445 & 0.014 & 0.023 & 0.190 & 0.777 & 0.002 & 0.284 & 0.919 \\
\hline 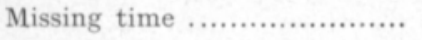 & 0.758 & -0.017 & 0.004 & 0.095 & 0.262 & -0.002 & 0.336 & 0.766 \\
\hline 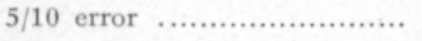 & -0.025 & 0.016 & 0.033 & -0.017 & 0.449 & 0.025 & -0.022 & 0.205 \\
\hline Time after missing time ...... & 0.307 & 0.005 & 0.024 & 0.084 & 0.192 & 0.010 & 0.051 & 0.141 \\
\hline Element code error ............... & 0.233 & 0.012 & 0.075 & 0.066 & 0.114 & 0.003 & 0.876 & 0.845 \\
\hline Missing element code ........... & 0.307 & 0.012 & 0.043 & 0.054 & 0.098 & 0.620 & 0.865 & 0.858 \\
\hline Gross error ...................... & -0.154 & -0.003 & $0 . \cos$ & -0.060 & 0.346 & -0.006 & 0.042 & 0.145 \\
\hline Faultless result $\ldots \ldots \ldots \ldots \ldots \ldots \ldots$ & -0.244 & -0.115 & 0.052 & -0.047 & -0.415 & -0.026 & 0.017 & 0.251 \\
\hline
\end{tabular}

Factors:

1. Missing times and negative systematic errors

2. Practice in time studies

3. Suitability of test person for timing in the existing measuring circumstances

4. Length of the time to be measured

5. Unsystematic human error

6. Test person's talents

7. Disturbed measuring situation

factors denoting the use of different timing instruments and methods. It came as a surprise that the basic material gave no factor connected with the time to be measured despite the fact that the scope for variations in basic times was clearly wider than in the human factors material.

On the basis of the analysed results the different factors affecting the accuracy of the timing phase in measuring situations also in practice may be primarily grouped together as follows:

- Equipment and method used in time study

- Possibility to observe the break point

- Magnitude of measured times

- Training and skill of the investigator

- Intelligence of the investigator

- Human factors at the timing situation 
The first three groups are connected with the measuring method and the work and are, as a rule, known already before the measuring situation. The rest are connected with the investigator. As to these, the training and talents are either known or determinable in advance, even if not very accurately. In general, in practical measuring situations the effect of human factors is always unknown.

In order to test the hypothesis presented here it would be interesting to find out the share of each group of variables in the measuring errors. Within the framework of the study material this is not possible, however, owing to two reasons:

- The different variable groups are based on different part materials and can not be combined without leaving out some information (so-called missing value), which again has a negative effect on the results (ANON 1974 b).

- The criteria of the measuring accuracy were included when the variable groups, the factors, were formed. The variables denoting the effects of these groups, the factor points, are in some cases based almost entirely on the dependent variables, in other words the criteria of the measuring accuracy, and consequently their use in models as independent variables, does not seem justified.

Although it is not possible to test the hypothesis directly, it is possible to estimate the effects of the factor groups on the basis of the results which will be presented in the following chapter.

\section{The explaining models for measuring accuracy}

The simultaneous effect of several variables on the measuring accuracy was subjected to a linear regression analysis. Admittedly the use of this method presents in this connection certain difficulties. There are, for example, strong correlations between the independent variables. Similarly, some of them may only be graduated in an ordinal scale and even so in a rather broad sense of the word.

The number of independent variables as compared to the number of observations is low in the study material. In a situation like this the fraction of variance explained by the model often remains low, unless there is a clear causal dependence between the independent and the dependent variables, which can not be shown in the present case. In explaining the models, the small amount of independent variables is, on the other hand, an advantage and likewise the large number of observations.

It would have been possible to cut down the number of independent variables even from the present number by combining with factor analysis, deviating from what has been done earlier, only the original independent variables and by counting the corresponding factor points. This would have reduced also the correlations between the new independent variables. In the models it was, nevertheless, decided to use the original variables since it would be difficult to combine factor points given by a certain calculation scheme to depict a measuring situation in practice. 
Owing to the correlations between independent variables, the constant term of the regression models and the coefficients of the variables vary in the different steps of a stepwise analysis. In a situation of this kind the variables entered into a model do not necessarily have the greatest power of explaning and the model is, therefore, in its entirety not the best possible one.

The scales of the independent variables are not identical and it is thus not possible on the basis of the regression coefficients to obtain a clear picture of the effects of the different variables. The models will therefore be presented, instead of as normal regression equations, in the form of tables (Tables 13 ... 22) completed in such a way that the differences between the scales can be taken into account. Owing to the dependencies between the variables, the corresponding correlation and regression coefficients may point in opposite directions. It is consequently not always possible to estimate from the models the direction of the effect of a specific variable solely on the basis of its regression coefficient.

\section{Models of the basic material}

The independent variables in the models of the basic material may be divided into groups that have formed the basis of the test arrangement as follows:

- Job to be studied: 3 variables

- Study conditions: 8 variables

- Groups of measuring instruments, instruments and methods: 12 variables

- Test persons: a total of 10 variables, of which 8 are dichotomic variables describing the different test persons and 2 variables denote the level of training.

In the first phase were performed the analyses in which the different criteria of the measuring accuracy were used as the dependent variables and the 32 different variables served as optional independent variables. In adding variables to the models or in eliminating them, the F-value 2.0 of the regression coefficient was used as the acceptance or rejection limit. The fraction of variance explained by all the models remained low (Table 12), which shows that the differences between the measuring instruments and methods, the jobs to be studied, the study conditions and the test persons do not explain more than a small proportion $(0.4 \ldots 4.4 \%)$ of the total variation in the variables used as criteria in the measuring accuracy. The influence of the differences between the test persons was small, because when the 8 variables applying to the test persons were dropped from the analyses, the fractions of variance explained by the models were almost unchanged.

Although the explaining power of the models remained low, it is useful to examine the order of entry into the model of different variables and their power of explaining after the last step.

The first variable to enter the model denoting the share of missing times (Table 13) was the magnitude of the time to be measured (master value). Its power of explaining declined somewhat when new variables entered the model. Specific test persons, type of time study instrument and training in the use of certain equipment had also some power to explain whether the times had or had not been measured. 
Table 12. Proportions of variance explained by linear regression models of measuring accuracy criteria in basic material in its normally recorded results.

\begin{tabular}{|c|c|c|c|c|c|c|c|}
\hline \multirow[b]{2}{*}{$\begin{array}{l}\text { Criterion of } \\
\text { measuring accuracy }\end{array}$} & \multicolumn{4}{|c|}{$\begin{array}{l}\text { Optional independent } \\
\text { variables } 33 \mathrm{psc}\end{array}$} & \multicolumn{3}{|c|}{$\begin{array}{l}\text { Optional independent variables } \\
25 \mathrm{psc} \\
\text { (= previous } 33-8 \text { test persons) }\end{array}$} \\
\hline & $\begin{array}{c}\text { Proportion of } \\
\text { explained } \\
\text { variance } \\
\%\end{array}$ & F-value & $\begin{array}{l}\text { No. of } \\
\text { variables } \\
\text { in the } \\
\text { model }\end{array}$ & $\begin{array}{l}\text { Model in } \\
\text { Table no. }\end{array}$ & $\begin{array}{c}\text { Proportion of } \\
\text { explained } \\
\text { variance } \\
\%\end{array}$ & F-value & $\begin{array}{c}\text { No. of } \\
\text { variables } \\
\text { in the } \\
\text { model }\end{array}$ \\
\hline Absolute measuring error ...... & 0.8 & 21.29 & 15 & - & 0.7 & 27.74 & 10 \\
\hline Absolute deviation ............... & 0.8 & 24.26 & 13 & 17 & 0.7 & 33.15 & 8 \\
\hline Proportional measuring error & 0.5 & 13.47 & 15 & - & 0.5 & 16.31 & 11 \\
\hline Proportional deviation .......... & 2.7 & 75.66 & 14 & 18 & 2.5 & 95.97 & 10 \\
\hline 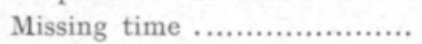 & 1.5 & 34.65 & 16 & 13 & 0.8 & 31.37 & 10 \\
\hline 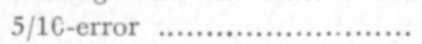 & 0.5 & 15.55 & 13 & 14 & 0.4 & 13.16 & 12 \\
\hline 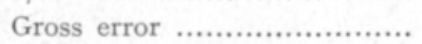 & 0.4 & 15.40 & 10 & 15 & 0.4 & 18.18 & 8 \\
\hline Faultless result ..................... & 4.4 & 89.86 & 19 & 16 & 3.7 & 121.57 & 12 \\
\hline
\end{tabular}

Table 13. A regression model showing how missing times develop in normally recorded results of basic material.

\begin{tabular}{|c|c|c|c|c|c|}
\hline VARIABLE & REGR. C & ITS ST. D & STAND. C & T VALUE & INC. IN MCS \\
\hline Master value $\ldots \ldots \ldots \ldots \ldots \ldots$ & -0.6064 & 0.0000 & -0.0532 & -9.94 & 0.6026 \\
\hline Type of equipment .......... & $-0.01 C 5$ & 0.0012 & -0.0521 & -8.52 & 0.0019 \\
\hline Test person 4 ............... & C. 0265 & 0.0024 & 0.0740 & 11.14 & 0.0033 \\
\hline Test person $2 \ldots \ldots \ldots \ldots \ldots . . .$. & 0.0226 & $0.0 \mathrm{C} 24$ & 0.0577 & 9.27 & 0.0023 \\
\hline Test person $7 \ldots \ldots \ldots \ldots \ldots$ & 0.0213 & 0.0023 & 0.0585 & 9.09 & 0.0022 \\
\hline Training to use specific & & & & & \\
\hline equipment .................... & -0.0015 & 0.0003 & -0.0703 & -5.26 & $0.00 c 7$ \\
\hline Test person 6 ............... & 0.0161 & 0.0029 & 0.0328 & 5.50 & 0.0008 \\
\hline 3-watch board .............. & 0.0083 & 0.0019 & 0.0243 & 4.48 & 0.0005 \\
\hline No. of replications ........... & 0.0014 & 0.0004 & 0.0171 & 3.29 & 0.0003 \\
\hline Test person $5 \ldots \ldots \ldots \ldots \ldots$ & 0.0071 & 0.0026 & 0.0196 & 2.90 & 0.0002 \\
\hline Alarm before break point & -0.0094 & 0.0024 & -0.0214 & -3.87 & 0.0004 \\
\hline Dim light ..................... & -0.0098 & 0.0029 & -0.0183 & -3.32 & 0.0003 \\
\hline Training in general .......... & 0.0001 & 0.0000 & 0.0452 & 3.35 & 0.0003 \\
\hline Test person $8 \ldots \ldots \ldots \ldots \ldots \ldots$ & -0.0052 & 0.0027 & -0.0123 & -1.92 & 0.0001 \\
\hline Distance of isolation ....... & -0.0057 & 0.0030 & -0.0103 & -1.89 & 0.0001 \\
\hline $\begin{array}{l}\text { Dim light and noisy condit- } \\
\text { ions } \ldots \ldots \ldots \ldots \ldots \ldots \ldots \ldots \ldots \ldots\end{array}$ & -0.0077 & 0.0044 & -0.0099 & -1.77 & 0.0001 \\
\hline
\end{tabular}

Const. term 0.0423

Proportion of explained variance $1.5 \%$ F- value 34.65 Risk $0.00 \%$

The variables denoting the use of the cumulative timing method entered first the model indicating the share of the 5/10 error. Later however, it was dropped from the model. In the end (Table 14), the variable explaining the greatest fraction of variance was the one denoting the general increase of skill in the course of the study. Its direction was positive. The variable denoting the progress in learning to use a specific time measuring instrument had the 
Table 14. A regression model showing how 5/10 errors develop in normally recorded results of basic material.

VARIABLE

REGR. C ITS ST. D STAND. C T VALUE INC. IN MCS

\begin{tabular}{|c|c|c|c|c|c|}
\hline $\begin{array}{l}\text { Cumulative timing, watch } \\
\text { with split action }\end{array}$ & 0.0092 & c.0022 & 0.0335 & 4.12 & 0.0004 \\
\hline Master value ..................... & -0.0001 & 0.0000 & -0.0101 & -1.84 & 0.0001 \\
\hline Training in general ........... & 0.0004 & 0.0000 & 0.1212 & 9.37 & 0.0023 \\
\hline Test person 6 ................ & $0.015 c$ & 0.0026 & 0.0311 & 5.82 & 0.0009 \\
\hline Alarm before break point & -0.0149 & 0.0024 & -0.0347 & -6.06 & 0.0010 \\
\hline Test person $7 \ldots \ldots \ldots \ldots \ldots$ & 0.0074 & 0.0019 & 0.0208 & 3.96 & 0.0004 \\
\hline Printer $\ldots \ldots \ldots \ldots \ldots \ldots \ldots$ & -0.0144 & 0.0029 & -0.0330 & -5.01 & 0.0007 \\
\hline Distance of isolation ....... & -0.0131 & 0.0030 & -0.0242 & -4.35 & 0.0005 \\
\hline No disturbance $. . . \ldots \ldots \ldots . . . .$. & 0.0113 & 0.0027 & 0.0313 & 4.17 & 0.0005 \\
\hline Noisy conditions $\ldots \ldots \ldots \ldots$ & 0.0112 & 0.0036 & 0.0199 & 3.15 & 0.0003 \\
\hline Stopped pointer .............. & 0.0036 & $0 . c 016$ & 0.0138 & 2.30 & 0.0001 \\
\hline Training to use specific & & & & & \\
\hline equipment .......................... & -0.0018 & 0.0003 & -0.0868 & -7.09 & 0.0013 \\
\hline No. of replications ............ & -0.0010 & 0.0004 & -0.0120 & -2.30 & 0.000 \\
\hline
\end{tabular}

Const. term -0.0012

Proportion of explained variance $0.5 \%$ F-value 15.55 Risk $0.06 \%$

Table 15. A regression model showing how gross errors develop in normally recorded results of basic material.

\begin{tabular}{|c|c|c|c|c|c|}
\hline VARIABLE & REGR. C & ITS ST.D & STAND. C & T VALUE & INC. IN MCS \\
\hline Cumulative timing $\ldots \ldots \ldots . .$. & 0.0111 & 6.0015 & 0.0621 & 7.29 & 0.0014 \\
\hline Printer ......................... & 0.0064 & 0.0021 & 0.0270 & 3.02 & 0.0002 \\
\hline Noisy conditions $. . . \ldots \ldots . . .$. & 0.0078 & 0.0017 & 0.0255 & 4.63 & 0.0006 \\
\hline Test person $6 . \ldots \ldots \ldots \ldots \ldots$ & 0.0037 & 0.0014 & 0.0142 & 2.67 & 0.0602 \\
\hline Cumulative timing, watch & & & & & \\
\hline with split action ............. & -0.0046 & 0.0018 & -0.0216 & -2.60 & 0.0002 \\
\hline Distance of isolation ....... & 0.0043 & 0.0016 & 0.0145 & 2.72 & 0.0002 \\
\hline Training in general .......... & -0.0000 & 0.0000 & -0.0131 & -2.27 & 0.0001 \\
\hline Master value $\ldots \ldots \ldots \ldots \ldots \ldots$ & 0.0000 & 0.0000 & 0.0089 & 1.70 & 0.0001 \\
\hline Type of equipment .......... & -0.0014 & 0.0010 & -0.0135 & -1.47 & 0.0001 \\
\hline Test person $8 \ldots \ldots \ldots \ldots \ldots$ & 0.0017 & 0.0012 & 0.0075 & -1.43 & 0.0001 \\
\hline
\end{tabular}

Const. term 0.0063

Proportion of explained variance $0.4 \%$ F-value 15.40 Risk $0.06 \%$

second largest increase in the multiple correlation square. This coefficient was negative. Both the corresponding correlation coefficients were, on the other hand, positive.

The variable denoting the cumulative timing method was likewise the first to enter the gross errors model. In contrast to the situation in the preceding model, its fraction of explained variance remained high also right to the end (Table 15), although the other variables entering the model lowered its power. The third variable to enter was the one denoting noisy conditions. In the last step its increase in the multiple correlation square was the second largest. 
Table 16. A regression model showing haw faultless measuring results develop in normally recorded results of basic material.

\begin{tabular}{|c|c|c|c|c|c|}
\hline VARIABLE & REGR. C & ITS ST. D & STAND. C & T VALUE & INC. IN MCS \\
\hline Normal stop watch .......... & -0.1578 & 0.0078 & -0.1222 & $-2 C .21$ & 0.0104 \\
\hline Master value .................. & 0.0021 & 0.0001 & 0.0738 & 13.92 & 0.0049 \\
\hline Coldness ............................. & -0.1039 & 0.0164 & -0.0415 & -6.34 & 0.0010 \\
\hline Test person $8 \ldots \ldots \ldots \ldots \ldots . . . .$. & 0.1306 & 0.0110 & 0.0857 & 11.83 & 0.0036 \\
\hline 3-watch board $. . . \ldots \ldots \ldots . . . . .$. & 0.0697 & C.0079 & 0.0563 & 8.88 & 0.0020 \\
\hline Digital watch .................. & 0.0255 & 0.0090 & 0.0205 & 2.82 & 0.0002 \\
\hline Test person $7 \ldots \ldots \ldots \ldots \ldots$ & -0.0190 & 0.0081 & -0.0145 & -2.36 & 0.0001 \\
\hline Alarm before break point & 0.0765 & 0.0086 & 0.0484 & 8.89 & 0.0020 \\
\hline Training in general .......... & -0.0013 & 0.0002 & -0.1199 & -7.63 & 0.0015 \\
\hline Test person $2 \ldots \ldots \ldots \ldots \ldots$ & 0.0762 & 0.0092 & C.0537 & 8.30 & 0.0016 \\
\hline $\begin{array}{l}\text { Training to use specific } \\
\text { equipment } \ldots \ldots \ldots \ldots \ldots \ldots \ldots \ldots\end{array}$ & 0.0072 & 0.0012 & 0.0935 & 5.82 & 0.0009 \\
\hline Test person $1 \ldots \ldots \ldots \ldots \ldots . .$. & 0.0683 & 0.0111 & 0.0356 & 6.13 & 0.0010 \\
\hline Test person 4 ................. & 0.0350 & 0.6079 & 0.0271 & 4.44 & 0.0005 \\
\hline $\begin{array}{l}\text { Dim light and noisy } \\
\text { conditions } \ldots \ldots \ldots \ldots \ldots \ldots \ldots\end{array}$ & 0.0399 & 0.0158 & 0.0142 & 2.53 & 0.0002 \\
\hline Type of equipment .......... & -0.0182 & C.0658 & --0.0249 & -3.13 & 0.0002 \\
\hline Hearing isolation $. . . \ldots \ldots \ldots . . .$. & 0.0259 & 0.0107 & $0 .(162$ & 2.42 & 0.0001 \\
\hline Type of job ..................... & 0.0080 & 0.0031 & 0.0139 & 2.57 & 0.0002 \\
\hline Test person $3 \ldots \ldots \ldots \ldots \ldots . . . .$. & 0.0165 & 0.0091 & 0.0116 & 1.83 & 0.0001 \\
\hline $\begin{array}{l}\text { Cumulative timing, watch } \\
\text { with split action } \ldots \ldots \ldots \ldots \ldots\end{array}$ & -0.0142 & $0.0 C 85$ & -0.0098 & -1.67 & c.0001 \\
\hline
\end{tabular}

Const. term 0.6085

Proportion of explained variance $4.4 \%$

F-value 89.86 Risk $0.00 \%$

The first variable entering the model describing the share of faultless measuring result was the variable with a negative coefficient indicating the use of the stop watch. The increase in the multiple correlation square affected by it showed a clear drop when new variables entered the model. Nevertheless, in the last step its fraction of explained variance was the greatest of all the variables included in the model (Table 16). In addition to this variable, the master value as well as a variable describing a certain test person explained a relatively high proportion of the variance.

The first variable to enter the model of absolute deviation was the one denoting the use of the printer. The fraction of variance explained at this step was $0.4 \%$. At the end of the run (Table 17), when the model had explained $0.8 \%$ of the variance, the corresponding increase in the multiple correlation square had dropped to $0.2 \%$. The second largest increase in the multiple correlation square, $0.1 \%$, was connected with the master value.

In the model of relative deviation obviously the most important variable was the master value (Table 18), which in this model had a negative coefficient in contrast to the preceding model. The power of explaining of the other variables was less than $1 / 10$ of the power of the master value. 
Table 17. A regression model of absolute deviation in normally recorded results of basic material.

\begin{tabular}{|c|c|c|c|c|c|}
\hline VARIABLE & REGR. C & ITS. ST. D & STAND. C & T VALUE & INC. IN MCS \\
\hline Printer ......................... & 1.0318 & 0.1292 & C.0744 & 7.99 & $0 . \mathrm{C} 017$ \\
\hline Cumulative timing $\ldots \ldots \ldots . .$. & 0.3018 & 0.0568 & C. 0288 & 5.31 & 0.0007 \\
\hline Master value ................. & 0.0083 & 0.0013 & 0.0344 & 6.51 & $0 . c 011$ \\
\hline Alarm before break point & -0.3461 & 0.0719 & -0.0255 & -4.81 & 0.0006 \\
\hline No disturbance ............. & 0.3568 & 0.0747 & 0.0310 & 4.78 & 0.0006 \\
\hline Test person $4 \ldots \ldots \ldots \ldots \ldots . . . .$. & 0.3632 & 0.0638 & 0.0327 & 5.69 & 0.0009 \\
\hline Test person $2 \ldots \ldots \ldots \ldots \ldots . . . .$. & 0.3353 & 0.0689 & 0.0275 & 4.87 & 0.0006 \\
\hline Stopped pointer ............. & -0.2048 & 0.0538 & -6.0248 & -3.81 & 0.0004 \\
\hline Test person $7 \ldots \ldots \ldots \ldots \ldots$ & 0.2559 & 0.0649 & 0.0226 & 3.94 & 0.0004 \\
\hline Test person $6 \ldots \ldots \ldots \ldots \ldots$ & 0.3087 & 0.0845 & 0.0207 & 3.65 & 0.0004 \\
\hline Noisy conditions $\ldots \ldots \ldots \ldots . . .$. & 0.2701 & 0.1132 & 0.0150 & 2.39 & 0.0002 \\
\hline Test person $3 \ldots \ldots \ldots \ldots \ldots$ & 0.1138 & 0.0696 & 0.0093 & 1.64 & 0.0001 \\
\hline Type of equipment .......... & 0.0976 & 0.0684 & 0.0156 & 1.43 & 0.0001 \\
\hline
\end{tabular}

Const. term 0.1484

Proportion of explained variance $0.8 \%$ F-value 24.26 Risk $0.00 \%$

Table 18. A regression model of proportional deviation in normally recorded results of basic material.

\section{VARIABLE}

REGR. C ITS. ST. D STAND. C T VALUE INC. IN MCS

\begin{tabular}{|c|c|c|c|c|c|}
\hline Master value $. . . . . \ldots \ldots \ldots . . . .$. & -0.1878 & 0.0083 & -0.1272 & -22.73 & 0.0134 \\
\hline Cumulative timing $\ldots \ldots \ldots . .$. & 2.4307 & 0.3789 & C.0376 & 6.41 & 0.0011 \\
\hline 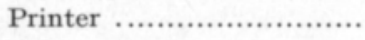 & 1.2932 & 0.6301 & 0.0151 & 2.05 & 0.0001 \\
\hline Test person 5 ................ & -1.9443 & 0.3882 & -0.0280 & -5.01 & 0.0007 \\
\hline Test person $8 \ldots \ldots \ldots \ldots \ldots$ & -3.4576 & 0.4994 & -0.0429 & -6.92 & 0.0012 \\
\hline Test person $3 \ldots \ldots \ldots \ldots \ldots$ & -2.7316 & 0.4101 & -0.0361 & -6.66 & 0.0011 \\
\hline Test person $1 \ldots \ldots \ldots \ldots \ldots . . . . .$. & -2.9455 & 0.5486 & -0.0290 & -5.42 & 0.0008 \\
\hline Hearing isolation $. . . \ldots \ldots \ldots . . .$. & 1.2233 & 0.5313 & 0.0144 & 2.30 & 0.0001 \\
\hline Alarm before break point & -2.9707 & 0.4898 & -0.0355 & -6.06 & 6.0010 \\
\hline Training in general $\ldots \ldots .$. & 0.0595 & 0.0091 & 0.1018 & 6.54 & 0.0011 \\
\hline No disturbance............ & 3.1225 & 0.5586 & 0.0441 & 5.59 & 0.0008 \\
\hline Training to use specific & & & & & \\
\hline equipment.....$\cdots \cdots \cdots \cdots$ & -0.2643 & 0.0632 & -0.0649 & -4.18 & 0.0005 \\
\hline Noisy conditions ............. & 1.8888 & 0.6912 & 0.0171 & 2.73 & 0.0002 \\
\hline Taylor-watch.............. & -0.6510 & 0.3537 & -0.0098 & -1.84 & 0.0001 \\
\hline
\end{tabular}

Const. term 6.8597

Proportion of explained variance $2.7 \%$

F-value 75.66 Risk $0.00 \%$

\section{Models in the human factors material}

A total of 15 different variables were used as independent variables in the human factors material. They may be divided into three groups as follows: - Job to be studied: 1 variable (master value)

- Measuring situation: 4 variables

- Characteristics of the test person: 10 variables. 
The proportion of variance explained by the linear regression models remained low also in the human factors material. The models explained $1.7 \%$ of the variance in the model of the absolute deviation (Table 19) and $6.4 \%$ in the model of the proportional deviation (Table 20), in other words clearly more than the corresponding models in the basic material. The models of the human factors material are given in full in the report of the second part of the study (PEHKONEN 1975) and are here examined only in a summary form.

Table 19. A regression model of absolute deviation in human factors material.

\begin{tabular}{|c|c|c|c|c|c|}
\hline VARIABLE & REGR. C & IRS. ST. D & STAND. C & T VALUE & INC. IN MCS \\
\hline 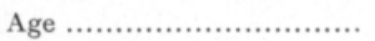 & 0.0218 & 0.0019 & 0.0713 & 11.21 & 0.0047 \\
\hline No. of experiment .......... & 0.2602 & 0.0263 & 0.0604 & 9.91 & 0.0036 \\
\hline Intelligence $\ldots . \ldots \ldots \ldots \ldots \ldots . . . . .$. & -0.1129 & 0.0117 & -0.0704 & -9.65 & 0.0034 \\
\hline $\begin{array}{l}\text { Professional connection to } \\
\text { work study } \ldots \ldots \ldots \ldots \ldots \ldots \ldots\end{array}$ & -0.0841 & 0.0162 & -0.0353 & -5.20 & 0.0010 \\
\hline Techno-mechanical talent & 0.0495 & 0.0699 & 0.0379 & 5.01 & 0.0009 \\
\hline Cumulative master value & 0.0002 & 0.0000 & 0.0232 & 3.81 & 0.0005 \\
\hline Position of test person $\ldots$ & 6,0028 & 0.0009 & 0.0204 & 3.07 & 0.0003 \\
\hline Vocational training .......... & -0.0462 & 0.0254 & -0.0121 & -1.82 & 0.0001 \\
\hline
\end{tabular}

Const. term 0.4046

Proportion of explained variance $1.7 \%$ F-value 55.89 Risk $0.00 \%$

Table 20. A regression model of proportional deviation in human factors material.

\begin{tabular}{lrrrrr}
\hline \multicolumn{1}{c}{ VARIABLE } & REGR. C & ITS. ST.D & STAND. C & T VALUE & INC. IN MCS \\
\hline & & & & & \\
Master value ................. & -0.7949 & 0.0205 & -0.2298 & -38.69 & 0.0528 \\
Age ......................... & 0.1953 & 0.0185 & 0.0657 & 10.54 & 0.0039 \\
Intelligence ................. & -1.0495 & 0.1110 & -0.0673 & -9.46 & 0.0032 \\
Techno-mechanical talent & 0.4560 & 0.0937 & 0.0359 & 4.87 & 0.0068 \\
Position of test person ... & 0.0282 & 0.0086 & 0.0215 & 3.28 & 0.0004 \\
Cumulative master value . & 0.0016 & 0.0004 & 0.0246 & 4.14 & 0.0006 \\
Professional connection to & & & & & \\
work study .................. & -0.5610 & 0.1615 & -0.0242 & -3.47 & 0.0004 \\
Vocational training ........... & -0.6366 & 0.2419 & -0.0172 & -2.63 & 0.0002 \\
Level of training ............ & -0.3980 & 0.2168 & -0.0120 & -1.84 & 0.0001 \\
\hline
\end{tabular}

Const. term 18.7792

Proportion of explained variance $6.4 \%$ F-value 201.79 Risk $0.00 \%$

In stepwise analysis the variable denoting the age of the test person is included in the models as the first or second variable. Its fraction of explained variance is not based merely on differences in age, however, but also on other connected factors. It is apparently for this reason that the variable denoting the level of training of the test person does not enter the model of the absolute deviation (Table 19). In the human factors material the scope of distribution in the master values was smaller than in the basic material, which explains 
why the master value does not enter the model of the absolute deviation even though it explains a considerable fraction of variance in the basic material.

Among the test results the amount of points denoting intelligence had considerable power of explaining, which is logical also in the light of the results presented by RUBENOwITZ (1971, p. 71). In the material intelligence is, however, dependent on a number of variables that are not in the model so that in fact some proportion of variance explained by it may be based on these.

In the so-called mean matrix the variables consist of the means calculated per test person as well as the standard deviations of quantitative criteria of accuracy. The variation in accuracy on the different occasions of timing does not here have the same effect as in the normal observation matrix. The proportion of variance explained by the model of the average absolute deviation did in fact now rise to $11.9 \%$ (Table 21) being thus sevenfold in comparison with the corresponding model in the normal observation matrix.

Table 21. A regression model for mean absolute deviation of the test persons.

\begin{tabular}{lrrrrr}
\hline \multicolumn{1}{c}{ VARIABLE } & REGR. C & ITS. ST. D & STAND. C & T VALUE INC. IN MCS \\
\hline Age ........................... & 0.0189 & 0.0062 & 0.2317 & 3.03 & 0.0473 \\
Vocational training ......... & -0.0120 & 0.0566 & -0.0156 & -0.21 & 0.0002 \\
Techno-mechanical talent & 0.0674 & 0.0318 & 0.3039 & 2.12 & 0.0232 \\
Professional connection to & & & & & \\
work study ................... & -0.0727 & 0.0511 & -0.1099 & -1.42 & 0.0104 \\
Intelligence .................. & -0.0678 & 0.0306 & -0.3231 & -2.22 & 0.0253 \\
\hline
\end{tabular}

Const. term 0.6684

Proportion of explained variance $11.9 \%$ F-value 4.64 Risk $0.05 \%$

In the mean matrix the variation in the measuring accuracy was indicated by the standard deviation of the measuring accuracy criteria. Among these the standard deviation of the absolute measuring error serves best to indicate the variation in accuracies between the different measurings. The proportion of variance explained by the deviation variable rose to about $7.4 \%$ with the model presented in Table 22, in which the age and both the test results of the test person had the greatest power of explaining.

Table 22. A regression model for deviation variable of the absolute measuring error of test persons.

\begin{tabular}{|c|c|c|c|c|c|}
\hline VARIABLE & REGR. C & ITS. ST. D & STAND. C & T VALUE & INC. IN MCS \\
\hline 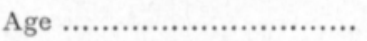 & 0.0199 & 0.0117 & 0.1303 & 1.71 & 0.0157 \\
\hline Basic schooling $\ldots . . . . . . . .$. & -0.1272 & 0.1199 & -0.0805 & -1.06 & 0.0061 \\
\hline Intelligence $\ldots . . . \ldots \ldots \ldots \ldots . . . .$. & -0.1439 & 0.0580 & -0.3658 & -2.48 & 0.0332 \\
\hline Techno-mechanical talent & 0.1274 & 0.0607 & C.3062 & -2.10 & c. 0237 \\
\hline
\end{tabular}

Const. term 1.5520

Proportion of explained variance $7.4 \%$ F-value 3.43 Risk $0.99 \%$ 


\section{Discussion of models}

As a summary of the models presented in Tables $13 \ldots 22$ it may be stated that in the normal observation matrix the models of measuring accuracy explained only a small fraction of the total variance of the criteria of accuracy. Using the variables known solely in the measuring situation it was not possible to compile from the material a linear regression model that would reliably explain the variations in measuring accuracy. If the variables denoting the occurrence of qualitative errors are adopted as independent variables, the explained variance in the models of quantitative criteria improves to a considerable extent (see Ch. 23, p. 24). Models of this kind do not, however, have any practical use since it is not possible to explain reliably the occurrence of qualitative errors. The F-values of the models are, nevertheless, not over four times greater when compared to the value of the corresponding F-distribution so that their ability of estimating the accuracy may be rated as poor (DRAPER and SMith 1967).

The form of results used in Tables $13 \ldots 22$, which is similar to the write out formate of the Hylps-system, gives a rather good picture of the explaining power of the different variables. As this picture of power is based on square sums it is useful to study also the residuals. According to Korhonen (1974), it is advisable to examine, among other points, the distribution of residuals in the entire material and to study whether the values or the residuals in the entire material are dependent on the dependent variable. In this way it would be possible to shed additional light on the way the models enter the materials, what kind of observations they explain as well as the kinds they do not explain.

When examining the distribution of the residual variables calculated from the absolute and relative deviation models of the basic material (Table 23) it may be noted that neither the residual variables nor the corresponding dependent variables follow the normal distribution. In this respect the test results presented in connection with the regression models may be faulty since their calculation method in the Hylps-system presupposes a normal distribution of variables (KORHONEN 1974).

On the basis of the residuals it appears that the models explain better the variations in the measuring accuracy than may be expected only on the basis of the fraction of explained variance. In the model of absolute deviation presented in Table 17 (p. 51), the absolute value of the residual variable is in $31 \%$ of the observations at most $0.25 \mathrm{cmin}$ per measurement (Table 23). In the model calculated on measured observations the corresponding figure is $47 \%$. In the model based on Table 19 of the human factors material, the residuals have in $35 \%$ of the observations an absolute value of at most $0.25 \mathrm{cmin}$ per measurement (Penkonen 1975). Above it has been established that owing to the difference in the output accuracy between the master value and the measured value there is an average addition to the absolute deviation of approximately $0.25 \mathrm{cmin}$ per measurement. The models presented can explain with an accuracy of $\pm 0.5 \mathrm{cmin}$ per measurement approximately $70 \%$ of all the observations in the basic material and approximately $86 \%$ of its measured observations. The model presented in the basic material in the relative deviation, Table 18, explains with an accuracy of $\pm 5 \%$ approximately 
Table 23. The distribution of residual variables of the regression model of absolute and proportional division of basic material according to Tables 17 and 18 .

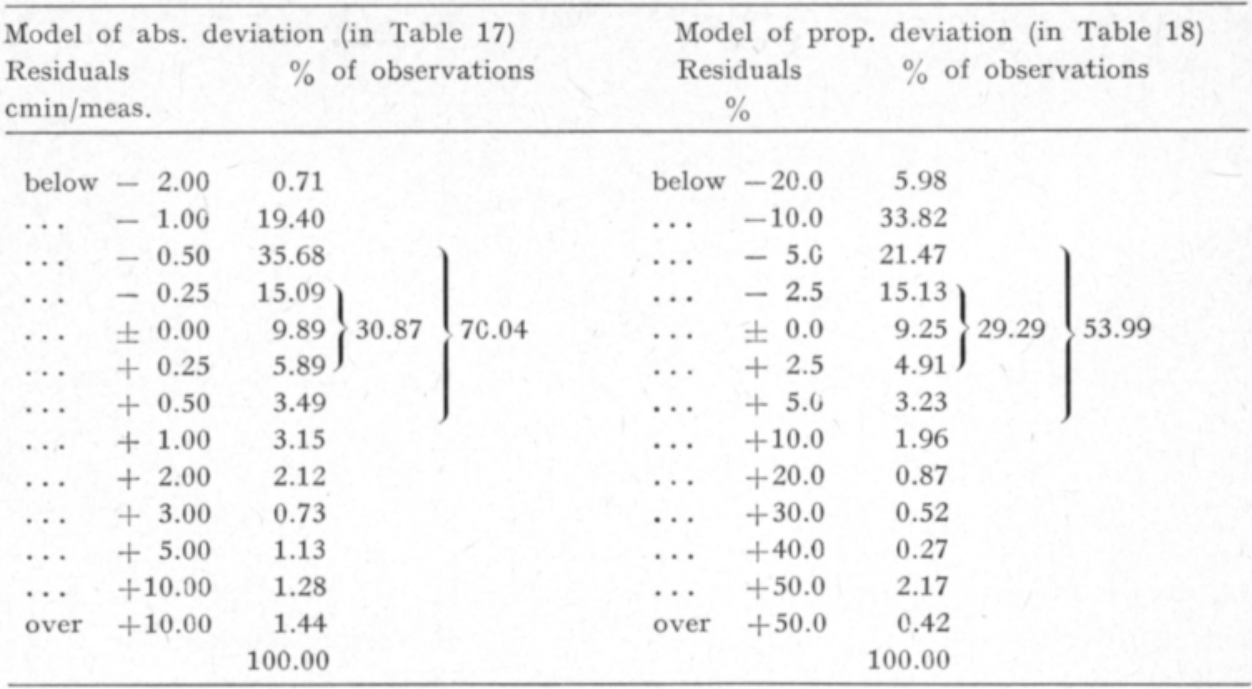

$54 \%$ of all the observations, and the model calculated on the measured times $72 \%$ of them.

The residual variable is in all the presented models clearly dependent on the corresponding Y-variable. Its standard deviation likewise shows a clear increase in the largest error categories, in other words the models explain very inadequately exceptionally faulty measuring results. This can be clearly seen also when residuals are studied with the aid of variables denoting the presence of different kinds of qualitative measuring errors. The models are not able to show if there is a specific qualitative measuring error in some single measuring result. In this kind of situation the value of the residual variable is therefore very high.

Although an examination of the residuals does not in any way affect the variance explained by the models, it helps in this situation to formulate a more complete and varied picture of the ability of the models to explain the variations of the measuring accuracy than would be possible when examining only the multiple correlation square, which is based on square sums. The differing output accuracy of the master value and the measured value is reflected in the quantitative criteria of the measuring accuracy as well as in their models, thus reducing the proportion of variance explained by the models. When this proportion is $0.8 \%$ in the absolute deviation model, it means in fact that approximately $30 \%$ ot the observations may be explained as well as it is possible within the framework of the material.

\section{Discussion and conclusions}

In the opinion of the test persons the series of events established in the laboratory with the aid of the work study simulator was, as an object of the time study, relatively analoguous with normal work. In their studies Hammer 
and Al-Nawam (1973) have reached a similar conclusion. In simulation the approach of the break point can not be noticed in advance, while in normal work this is often possible. According to the results, the unpredicted break point between events has had a negative effect on the measuring accuracy particularly with longer times. In contrast to a normal time study, the dimming of the light helps in the observation of the break point when the work study simulator with a light panel is used. In assessing and generalising the results obtained in the study it is advisable to take into consideration the deviating effects of these factors.

Judging by the results it is possible with a job breakdown to influence the measuring accuracy through the break point and the length of the elements. A clear break point and a chance to notice its approach in advance improve the measuring accuracy. The relative measuring accuracy shows a clear deterioration when the length of the elements is below $10 \ldots 15 \mathrm{cmin}$. The absolute effect, on the other hand, is small. The results obtained are very similar to results presented by Pukkila (1948), Lorenz (1962), Heinz (1967), Hammer and AL-NAwAm (1973), among others, although there are differences in the details. The results agree with the opinion presented in the literature to the effect that in watch studies or corresponding methods the element times to be measured should not be below $10 \ldots 20 \mathrm{cmin}$ (Anon. 1958, Heinz 1967). Nor does a lengthening of the times to well over $0.5 \mathrm{~min}$ improve the absolute measuring accuracy in normal cases.

From the point of view of measuring accuracy the recommended time for an element would seem to be approximately $15 \ldots 50 \mathrm{cmin}$ corresponding to the level of training of the test persons. By applying shorter elements it is indeed possible to have more detailed work specification although this takes place at the expense of the timing accuracy. A lenghtening of the elements tends to make the job specification more indefinite since it no longer improves the absolute measuring accuracy. If other information is collected in connection with the timing, for example the performance is rated, the required additional time should be taken in consideration in the job breakdown.

The majority of the test persons had rather scanty experience in work measuring. There were, however, differences in the levels of skill between the different persons as groups of persons. Practice acquired prior to the study, or increasing skill in the course of the study, had a positive effect on the quantitatively determined measuring accuracy. On the other hand, training did not significantly affect the proportion of large qualitative errors. The majority of these may have been due to various operational errors of the test persons. Judging by the basic material, it seems obvious that smallish differences in training do not affect the proportion of these errors and that even relatively large measuring errors due to human factors occur on all training levels.

The effect of the differences in ages between the test persons was surprisingly great because they involved also other factors, differences in levels of training, for example. When the test person's level of training is rather low, the study result of the human factors material indicates also skills and knowlegde learnt during the work study course. Since the schooltype learning of new things is usually a more familiar experience for the young than for the old, 
this is reflected in the results, expressly in the effects produced by the age differences, which is in conformity with the general lines presented by RuBENOWITZ (1971, p. 186).

Careful concentration on the timing by the test persons improved the accuracy, which was reflected in the results in two different ways. When the test persons of the basic material were unable in a given measuring situation to see or hear what happened around them, their measuring accuracy improved. In addition to the exceptional explicitness of the break point, this may be regarded as being also due to the fact that in the absence of other disturbing information sources their ability to receive information regarding the job under study was better than normally. The result conforms with the general lines presented by НӒкKINEN (1970) in regard to reception of information.

In the human factors material test persons without vocational training were clearly above the average level in the study involving the stop watch test of the work study course. They attended the course expressly in order to train as work study men. Consequently it seems they regarded a good test result as being of importance, they concentrated on it carefully and they also succeeded in their aim.

Judging by the above results, the practical measuring accuracy may be improved in two different ways. On the one hand it is advisable to avoid performing time studies in situations in which some external, exceptional factors disturb the investigator, and, simultaneously, also the worker, and affect, generally, also the length of the times.

As stated earlier (p. 8), it is not advisable to set a general accuracy requirement for work measurement results since the accuracy requirements clearly differ in different contexts. An accuracy requirement conforming to the planned use of the result should, therefore, be set for each specific case, and this should be explained to the investigator so as to make it possible for him to try to follow it.

Among the test results describing specific characteristics of the test persons, the number of points yielded by the so-called intelligence test showed an obvious dependence on the measuring accuracy, which fully agrees with the general effectivity lines presented, among others, by GHISELLI and Brown (1969, p. 229) and Rubenowitz (1971, p. 71). The timing does not, on the other hand, seem to require special techno-mechanical talents since the number of test points describing these and the measuring accuracy did not have an explicit dependence.

None of the variables indicating characteristics of the test persons are able to explain a large proportion of variance in accuracy, in fact, judging solely by these it is not possible to predict who is or will be a good time study man. An ability test adapted specifically for time study might conceivably increase the variance explained by test points, although it seems unlikely that it would bring about a sufficiently large improvement.

In practice the suitability of a person for time studies is more easily and with a higher degree of reliability ascertainable by a work test, for example along the lines of simulation used in the study. It would seem advisable for 
time investigators already employed in practical work to check their own timing accuracy in order to avoid, among others, systematic rounding errors. Corresponding checks are relatively common in rating of performances (Fornallaz 1952, Pietola 1971, Hotanen 1976). In view of the measuring accuracy required in this study (e.g. p. 26), additional checks to cover time measuring especially with beginners would seem justified.

The measuring accuracy was affected by the different timing instruments, although, when correctly used, it is possible to achieve a high level of accuracy with all of them. The biggest negative surprise came from the work study printer, with which the measuring accuracy was clearly poorer than had been expected on the basis of the results presented by Heinz (1967). It is possible that the printer used in the study happened to be an exceptionally poor specimen and that owing to some individual defects operational disturbances occurred more often than is normal.

Judging by the study, digital display did not in itself improve the measuring accuracy even though as an output system it is generally considered preferable to pointer display (HÄKKINEN 1970). Corresponding types of equipment have been used in their studies by Hammer and Al-Nawam (1973), and the result obtained in the present study is fully in line with their results. The unexpectedly poor success of the digital display may be connected with the type of digital watch used in the studies. The read out part is in the box used as a base for writing on. The position of the box in the timing depends primarily on the way the writing down is done. The read out part may thus happen to be in an unsuitable position, for example reflections in the glass protecting the face of the counters may hinder correct reading of the figures.

A comparison of instruments with different types of pointer displays shows a clear improvement in the measuring accuracy if the watch can be stopped blindly to show the result at break point, and the result can be read out and written down afterwards. For this purpose the watch should have a split action mechanism or there should be a system of $2 \ldots 3$ watches so that they can be synchronized with the same lever. Equipment of this kind can achieve a measuring accuracy similar to that of the digital watches.

In extensive work studies the calculating of final results may be made easier by a noting of the measurement results on punched cards directly in connection with the measuring. In the use of prepunched cards and punching sticks, the elements to be measured have to be sufficiently long, however, and the persons doing the timing have to have sufficient training in the method. Otherwise the measuring accuracy turns out to be very poor.

Certain lines of direction may be gained from the study results as regards the choice and development of timing equipment and methods. Since it appeared from the study that human factors proved to be the group of factors with the most extensive effect on the measuring accuracy, the choice and development of equipment should be on lines that would effectively limit the negative possibilities for human factors to influence the accuracy. In other words, the operation of the equipment should be uncomplicated and unambiguous and the formate of read outs should be clear and without possibilities for an erroneous interpretation. 
In comparing the studied equipment, on the one hand on the basis of the above principles, and on the other, on the basis of their prices and operating costs, watches with split action and combination boards with 2 or 3 watches seem the most suitable alternatives. The printer and the digital watch used in the study, on the other hand, are costly solutions when compared to their properties. Thanks to advances in the technique of electronics it is, however, possible considerably to improve the practical properties of equipment of this type, and to keep the price reasonable once the products are manufactured in sufficient quantities.

In view of further steps in the development of time study techniques it appears that the digital watch seems to be the one that will more commonly, although slowly, take the place of a normal stop watch. The printer will most likely represent only an interim stage when measuring devices are adopted that use a manifold computer registering process or built in calculation routines. Hammar and Al-Nawam (1973) maintain that with this kind of electronic timing equipment it is possible to achieve a very high level of measuring accuracy.

It also seems advisable, judging by the study results, to increase the information collected in connection with the timings. The accuracy of the times is not, after all, of value unless it is known exactly what they denote. Simultaneously with the measuring of times it should, therefore, be possible in the studies to measure or determine, among others, such parameters describing work conditions that affect the times to perform a job.

On the basis of the results obtained in the present study, the Laboratory of Applied Electronics of the Technical University of Helsinki and the Department of Agricultural Engineering, University of Helsinki, have developed as a joint project timing equipment that makes use of computers in the output phase (Ahjopalo 1974). This equipment is based on the solutions presented primarily by Lorenz (1963), Mäck (1965), Nord (1968) and HöBel (1970). The preliminary results obtained in regard to its operational properties and its measuring accuracy indicate the correctness of the line of development. Considerable, though not insuperable, difficulties have been encountered in the process of making the equipment simultaneously operationall secure, small in size and light in weight, as well as reasonable in cost.

As a whole the present study does not produce a great deal of new exact information regarding factors affecting the measuring accuracy in timing. According to the purpose of the study, it does, however, clearly indicate the general lines of direction and thereby creates new possibilities for developing time study methods and equipment and for improving the possibilities of taking into account factors that affect the accuracy of timing. 


\section{Summary}

The present study has been performed in laboratory conditions using as the studied job, instead of normal work, a series of events shown in a work study simulator operating on a light panel principle. The study consists of two separate part materials: the so-called basic material and the human factors material. The basic material was used for studying factors that generally affect accuracy in timing. In the human factors material the differences in the measuring accuracy were based on the properties of 177 test persons.

The following time study instruments and methods were used in the basic material:

- Work study printer Chronaprint

- Work study watch Chronarith with digital display

- Combination board Heuer with three watches

- Taylor-watch for fly-back timing

- Normal stop watch for fly-back timing

- Work study watch with split action for cumulative timing

- Normal stop watch used in accordance with cumulative timing

In the human factors material only a normal stop watch with fly-back timing was used.

In the basic material the time to be measured was $3 \ldots 115 \mathrm{cmin}(1 \mathrm{cmin}=$ $1 / 100 \mathrm{~min})$, the average being $23 \mathrm{cmin}$. The mean absolute deviation in the total basic material (39 255 observations) was $1.31 \mathrm{cmin}$ per measurement $(8.26 \%)$, in its normally written down results (37 548 observations) $1.12 \mathrm{cmin}$ per measurement $(7.51 \%)$, and $5.53 \mathrm{cmin}$ per measurement $(25,07 \%)$ in results punched directly in connection with the measurement (1 707 observations). In the human factors material (26550 observations), the average time to be measured was $14 \mathrm{cmin}$, which gave an absolute deviation of an average of $1.06 \mathrm{cmin}$ per measurement $(9.41 \%)$. The times that have not been measured have been added to the presented figures as errors of the magnitude of the unmeasured times in question.

The magnitude of the measured time affected the measuring accuracy. When the time was below $10 \mathrm{cmin}$ the proportion of the unmeasured times grew heavily. The magnitude of the elements affected likewise very clearly the relative deviation. A suitable lower time limit for the element time for the test persons would have been approximately $15 \ldots 20 \mathrm{cmin}$. External circumstances on the measuring location affected the measuring accuracy. When the conditions were favourable for observation of the break point, or when they limited information other than that emanating from the study object, the measuring accuracy improved.

There were clear differences in the measuring accuracies of the different kinds of equipment. The measuring accuracy of the printer was poorer than the average. The share of missing times, in particular, was high, which indicates possible individual operational and functional disturbances in the printer. The measuring accuracy of watches equipped with pointer display improved clearly if the pointer could be stopped at the moment of timing and the result read out afterwards. With watches of this kind the measuring accuracy was on a 
level with the digital watch. The punching of the results on punched cards done in connection with the timing produced considerably more errors than did normal writing down on paper with pencil.

The test persons used the different timing instruments in different ways. Judging by the results it appears that when the operating of the instrument gets simpler and there are fewer possibilities for wrong usage, the influence of the test person on the possible accuracy of the equipment is more limited.

In the human-factors material there were, likewise, clear differences in the measuring accuracy of the test persons. For as many as 14 test persons $(7.9 \%)$ the mean absolute deviation was below $0.5 \mathrm{cmin}$ per measurement. There were differences in the measuring accuracies of test persons of different ages. Since the age categories in the study involve other factors in addition to mere differences in age, such as differences in skill, the variation in accuracy can not be considered as being due only to the differences in age. With a higher level of basic education there was a clear improvement also in the measuring accuracy. As regards vocational training a corresponding direction was not to be seen, however.

Among the results of the adaptibility tests of the work study courses, the number of points in the so-called intelligence test was the one most clearly correlated to the measuring accuracy. On the other hand, there was not an obvious dependence between the accuracy of the timing and so-called techno-mechanical ability.

The different factors affecting the measuring accuracy in the timing phase may be grouped as follows:

1. Time study methods and equipment

2. Facility to observe break point

3. Time to be measured

4. Skill of the investigator

5. Human factors at the moment of measuring

With the aid of a linear regression model it was possible to explain only a very small proportion of variance of the measuring accuracy. Judging by the results it seems evident that with easily determinable characteristics it is not possible to give a reliable estimate as to whether a certain person is or will be a good time study investigator. This can be seen much more reliably for example through the work test, corresponding to simulation, as used in the study. 


\section{REFERENCES}

AнJopalo, H. 1974. Rekisteröintijärjestelmän suunnittelu maatalouden työntutkimusta varten. Study required for diploma at the Technical Univ. Helsinki, Lab. of Appl. Electronics. 67 p., 14 appendix.

von Alfthan, B. 1943. Johdatus työntutkimukseen. 136 p. Helsinki.

Anon. 1958. Zeitvorgabe. Das REFA-Buch 2:1-119. München.

- 1962. Promotion of Work Study in Agricultural and Horticultural Advisory Services. OECD-Docum. in Food and Agric. 39:1-223. Paris.

_ - 1970 a. Perusaikatutkimuksen virhelähteiden vaikutus tutkimustulokseen. Leaflet Pt 595 of Rastor valmennustoiminta 1 p. Helsinki.

- - 1970 b. Työsaavutus. Työntutkimus 17:1-22. Study duplicate of Tietomies work study course. Helsinki.

- - 1971 a. Maatalouden työnormit. Työtehoseuran julk. 155: 1-47.

_ - 1971 b. Rationalisointisanasto. Tuottavuus $6: 37-39,7: 31-36$.

_ - 1972 a. Hylps-käsikirja. Duplicate of Computing Centre, Univ. Helsinki. 232 p.

- 1972 b. Siivoustyön suunnittelun opas. Valtiovarainmin. järjestelyos. julk. 104 p. Helsinki.

- - 1973. Datenermittlung. REFA-Methodenlehre des Arbeitsstudiums 2: 1-437. München.

- -1974 a. ILO. Introduction to Work Study. 436 p. Geneva.

- 1974 b. Hylps-käsikirja. Duplicate of Computing Centre, Univ. Helsinki. 210 p.

— - 1975. Elpymisajan määritys. Leaflet issued by RANK-relaxion working group 197511-15. 18 p. Helsinki.

_ 1976. Hylps-käsikirja. Duplicate of Computing Centre, Univ. Helsinki. 231 p.

Aulanko, V. 1973. Nykyaikainen työnmittaus. Yritystalous 8:36-37.

- - , Hotanen, J. \& SAlonen, A. 1973. Standardiaikajarjestelmät ja niiden rakentaminen. 114 p. Tampere.

BAKER, H. A. 1976. Rating Factor in Work Measurement. Work Study 11: 19-27.

BArford, N. C. 1967. Experimental Measurement: Precision, Error and Truth. 143 p. London.

Barnes, R. M. 1968. Motion and time study. 799 p. New York.

Bosch, P., Liem, T. \& Gerritsen, J. 1975. Elemental Times in Agriculture (ETA), a tool for deriving Task Times for animal husbandry. Methods Time Measurement 2: 9-17.

Bäcklin, B., Jacobsson, S. \& Petrersson, E. 1965. Arbetsstudier i matematisk-statistisk belysning. Ing. vet. akad. medd. 141: 1-120. Stockholm.

Doebelin, E. 1966. Measurement Systems. Application and Design. 743 p. New York.

Draper, N. R. \& Smith, H. 1967. Applied regression analysis. 407 p. New York.

FEIN, M. 1973. Work Measurement Today. Work Study 2: 37-44, 3:35-44.

Fornallaz, P. 1948. Die Schätzung des menschlichen Leistungsgrades. Ind. Org. 5: 130-137, 6: $172-179$.

- -1950 . Neue Untersuchungen auf dem Gebiete der Schätzung des Leistungsgrades. Ind. Org. 11: 541-554.

- - 1952. Die Schätzung des Leistungsgrades mit Hilfe des Filmes. Ind. Org. 9: 252-261.

Ghiselli, E. \& Brown, C. 1969. Työelämän psykologia (trans. [English] by M. Jääskeläinen and F. Blanz). 375 p. Jyväskylä.

Grahm, L. \& Hertz, H. 1971. Fysikalisk mätteknik. 339 p. Uppsala.

HaArLAA, R. 1971. Filmianalyysi metsäteknisissä työntutkimuksissa. Suomen Puutalous 11: $324-326$.

Hammer, W. 1975. Arbeitszeit- und Beanspruchungsfunktionen. KTBL-Schrift 202: 1-195.

- - \& AL-Nawam, K. 1973. Vergleich der Genauigkeit unterschiedlicher Verfahren zur Messung des Arbeiszeitaufwandes. Arb. Max-Planck-Inst. Landarbeit und Landtechnik, Bad Kreuznach C-73/6: 1-30.

- - \& Heiland, H. 1967. Netzplantechnik und Planzeitwerte in der Landwirtschaft. 61 p. Darmstadt.

Hammerschmidt, G. 1964. REFA in der Landwirtschaft. 26 p. Darmstadt.

Haraldson, A. 1956. Arbetets effektivitet och organisation. Lantbrukets driftsekonomi. p. 111-178. Stockholm. 
Harstela, P. 1975. Työajan menekkiin ja työntekijän kuormittamiseen vaikuttavat tekijät eräissä metsätyömenetelmissä. Summary: Factors affecting the consumption of working time and the strain of the worker in some forest work methods. Commun. Inst. For. Fenn. 87.2. Repr. 130 p.

Hernz, K. 1957. Geräte zur Zeitmessung bei Arbeits- und Zeitstudien und ihre Einsatzmöglichkeiten. Forsch.ber. Nordrhein-Westfalen 1878: 1-47.

Herb, M. 1968. Zeitstudien an festem Arbeitsplatz bei kurz dauernden sich ständig wiederholenden Arbeitsvorgängen. Landarbeit und Technik 35:47-62.

Heuer, J. W. 1961. Technik der Handzeitmessung. Techn. Rundschau 14:17-19.

HrLF, H. 1957. Arbeitswissenschaft. 341 p. München.

Hotanen, J. 1976. Onko joutuisuutta määritelty turhaan yli 30 vuotta? Tuottavuus 3: 2628.

- - 1977. Havainnointitutkimus ja yrityksen aktiivinen kehittäminen. Tuottavuus 1: $8-11,25$.

Hovi, Lehmusкoski \& OJanen. 1967. Havainnointimenetelmä työntutkimuksissa. 128 p. Helsinki.

HäккіNen, S. 1970. Informaatio ja sen jäsentyminen. Ergonomia, p. 55-87. Porvoo.

HöвEL, E. 1970. Zeitmässe Hilfsmittel für das Arbeits- und Zeitstudium. Refa-Nachrichten 3: $169-174$.

JÄrVElärnen, V.-P. 1971. Vähäsen faktorianalyysistä. Silva Fenn. 3: 281-290.

Kaмınsкy, G. 1971. Praktikum der Arbeitswissenschaft. 327 p. München.

KARLSSON, E. 1970. Mätteknik. 127 p. Uppsala.

KEHR, B. 1968. Der Arbeitszeitbedarf für die Hausreinigung. KTL-Berichte über Landtechnik 120: $1-161$.

Kollar, L. \& KüHn, G. 1973. Messen, Steuern und Regeln in der Landtechnik. Landmaschinenlehre 1: 138-204. Berlin.

Korhonen, M. 1974. Regressio-, varianssi- ja kovarianssianalyysi sekä niiden käyttö Hylpsohjelmistossa. Helsingin yliopiston laskentakeskuksen tied. Opetusmoniste 1/74: $1-88$.

KraUSE, V. 1962. Zeiger oder Zahl? Landtechnik 17: 844-845.

- - 1964. Anleitung für Zeitstudien in der Landwirtschaft. Landarbeit und Technik 34: 47-84.

- - 1972. Chronaprint - Zeitstudiendrucker. Die Landarbeit 2:14-15.

_ _ \& Wasmund, L. 1962. Die Zeitstudie bei landwirtschaftlichen Arbeiten. 54 p. Publ. Max-Plack-Inst, Bad Kreuznach. ,

KÄRKKÄrNEN, M. 1971. Johdatus metsätyötieteen tutkimusmenetelmiin. Summary: An Introduction to the Research Methods in Forest Work Science. Hels.ngin yliopiston Metsäteknologian laitos. Tied. 13:1-51.

Leim, T. \& Gerritsen, J. 1968. Betractung über ETA-Elemental Times in Agriculture. Anwendung von System vorbestimmter Zeiten in der Land- und Forstwirtschaft. p. 43-54. Darmstadt.

Lorenz, F. R. 1962. Zur Frage der Erfassung kurzer Zeiten bei Arbeits- und Zeitstudien. Werkstatt und Betrieb 95: 283-287.

- -1963 . Stenophonisieren Sie schon? Refa-Nachrichten 16: 74-76.

- - 1966. Die Messlücke der Zeitstudientechnik ist geschlossen. Refa-Nachrichten 19: $279-284$.

Menneer, R. R. 1976. Labour and machine times for different farming conditions. 18. CIOSTA Congr. papers. 6 p. Gödöllö.

Mevert, P. 1963. Untersuchungen über die Genauigkeit von Multimomentstudien. 59 p. München.

Mundel, M. 1970. Motion and Time Study. 674 p. New Jersey.

MÄск, E. 1965. Neue Möglichkeiten der Messtechnik bei der Arbeits- und Zeitstudie. TZ für praktische Metallbearbeitung 395. Sonderdr. 8 p.

Nightingale, N. E. 1972. Työnmittaus 1. osa. Tuottavuus 6:26-29.

Nisula, P. 1963. Aikakello- ja pistokoemenetelmän vertailu. Summary: A comparison between the stop-watch method and the random sample method. Silva Fenn. 112. Repr. 19 p.

Nord, O. 1968. Zeitmessung mit dem Tonbandgerät. Landarbeit und Technik 35: 83-91. 
Ortrila, E. 1975. Ikkunapesumenetelmien vertailu koeolosuhteissa. Helsingin yliopiston Kodin teknologian lait. julk. 3/75: 1-138, 12 appendix.

OKsanen, E. H. 1968. A study of the Dairy Jobs by Activity Sampling on Viik experimental Farm. Publ. Work Efficiency Assoc. 126: 76-87. Helsinki.

- - , Helle, J. \& TaAtrola, P. 1973. Pylväshaittatutkimus. Helsingin yliopiston Maatal. työntekniikan lait. tutk.tied. 3:1-9, 34 appendix.

Olkкonen, T. \& Aulanko, V. 1972. Menetelmä- ja palkkaustekniikka. 217 p. Helsinki.

PEсннодd, E. 1964. Zeitmessung und Zeitmessgeräte im Arbeitsstudium. 72 p. Köln.

Pehkonen, A. 1973. Aikatutkimustekniikoista ja niiden ajanmittausvaiheen tarkkuudesta. Helsingin yliopiston Maatal. työtekniikan lait. tutk.tied. 5:1-159.

- - 1975. Inhimillisten tekijöiden vaikutuksesta ajanmittausvaiheen tarkkuuteen. Helsingin yliopiston Maatal. teknologian lait. tutk.tied. 12:1-105, 28 appendix.

PIETolA, E. 1971. Työajan normalisointitekniikat. Tuottavuus 2:18-19.

PuккılA, A. 1948. Aikatutkimuksen tekniikka vapaasti suoritettuun työhön vaikuttavien tekijöiden avulla tarkasteltuna. Abstr.: The technique of time study proper. 148 p. Imatra.

- 1959. Työtutkimus. 318 p. Helsinki.

Puткısтo, K. 1956. Tutkimuksia pyörätraktoreiden käytöstä puutavaran metsäkuljetuksessa. Summary: Investigation of the Use of Wheel Tractors for Forest Transports of Timber. Metsätehon julk. 36:1-310. Helsinki.

Rubenowrtz, S. 1971. Henkilöstöhallinto ja työpsykologia (transl. [English] by Pirkko TalvioJaatinen). 247 p. Helsinki.

Sanders, N. W. 1975. Precision in Work Measurement. Work Study 8:15-23.

SchWEITzER, H. 1963. Beiträge zur Methodik der Arbeitszeiterhebung und Arbeitszeitskalkulation in der Landwirtschaft. 142 p. Küsnacht.

SIPILÃ, M. 1946. Maatalouden työajan käyttō ja työntutkimus. Summary: Utilization of Working Hours and Efficiency Study in Agriculture. 630 p. Helsinki.

Steele, P. M. 1977. More frequent Rating Clinics improve Efficiency. Work Study 8: 8-11. STÜBler, E. 1972. Einführung in das Arbeitsstudium in der Hauswirtschaft. 98 p. Frankfurt.

Svensson, Y. \& Tiberg, S. 1972. Rationalisering - Arbetstudier - Arbetsmätning - Lönesystem. p. 269-457. Stockholm.

Säмкıнно, R. 1974. Temput ja kuinka ne tehdäăn. Jyväskylăn yliopiston kasvatustiet. lait. julk. 220: 1-180.

SäLlfors, F. 1945. Teollisuuden työntutkimukset (transl. [Swedish] by B. Wuolle). 427 p. Hel. sinki.

TAbernacle, J. B. 1975. Operational Research Techniques and the Work Study Enginee1 - 9. Work Study 1: 33-39.

WILKıNG, E. 1968. Einige Anwendungsbeispiele vorbestimmter Zeiten (nach MTM) füı Arbeiten im Obst- und Gemüsebau. Anwendung von Systemen vorbestimmter Zeiten in der Land- und Forstwirtschaft. p. 36-42. Darmstadt.

VörY, J. 1954. Eräiden metsätöiden aikatutkimusaineistojen analyysia. Summary: Analysis of Time Study Materials of Some Forest Jobs. Metsätehon julk. 31:1-114. Helsinki.

Zenker, R. 1970. Zur Rationalisierung der Arbeitsstudienmethodik. Betr. wirtsch. Forsch. Prax. 7/8: 422-425.

ÁBERG, V. 1968. Arbete - mer eller mindre. 54 p. Stockholm. 


\title{
Ajanmittauksen tarkkuudesta aikatutkimuksessa
}

\author{
Aarne Pehkonen \\ Helsingin yliopisto, Maatalousteknologian laitos
}

Tutkimus on suoritettu laboratorio-olosuhteissa käyttäen tutkittavana työnä todellisen työn asemesta valotauluperiaatteella toimivassa tyőntutkimussimulaattorissa näytettäväă tapahtumasarjaa. Tutkimus koostuu kahdesta eri osa-aineistosta, ns. perusaineistosta ja henkilöaineistosta. Perusaineiston avulla tutkittiin ajanmittauksen tarkkuuteen yleisesti vaikuttavia tekijöitä selvittämällä kahdeksan eri koehenkilön, eri tyyppisten töiden, mittausolosuhteiden sekä mittauslaitteiden vaikutus mittaustarkkuuteen. Henkilöaineistossa mittaustarkkuuden erot muodostuvat lähinnä 177 eri koehenkilön vaikutuksesta.

Perusaineistossa käytettiin seuraavia ajanmittauslaitteita ja menetelmiä:

- Työntutkimusprintteri Chronaprint

- Numeronäytöllä varustettu työntutkimuskello Chronarith

- Kolmen kellon yhdistelmälauta Heuer

- Kaksoisosoittimella varustettu palautusmenetelmäån soveltuva työntutkimuskello, ns. Taylor-kello

- Normaali palautuskello

- Kaksoisosoittimella varustettu jatkuvanajan menetelmään soveltuva työntutkimuskello

- Normaali palautuskello käytettynä jatkuvanajan menetelmän mukaisesti

Henkilöaineistossa käytettiin pelkästään normaalia palautuskelloa palautusmenetelmän mukaiseti.

Perusaineistossa mitattava aika oli $3 \ldots 115 \mathrm{cmin}(1 \mathrm{cmin}=1 / 100 \mathrm{~min})$ ollen keskimäärin 23 cmin. Keskimääräinen abs. poikkeama oli koko perusaineistossa (39 255 hav.) $1,31 \mathrm{cmin} /$ mittaus $(8,27 \%)$, sen normaalisti kirjatuissa tuloksissa (37 548 hav.) $1,12 \mathrm{cmin} / \mathrm{mittaus}(7,51 \%)$ ja $5,53 \mathrm{cmin} /$ mittaus $(25,07 \%)$ suoraan mittauksen yhteydessä lävistämällä kirjatuissa tuloksissa (1 707 hav.). Henkilöaineistossa (26 550 hav.) mitattava aika oli keskim. 14 cmin, jolloin abs. poikkeamaksi muodostui keskim. 1,06 cmin/mittaus $(9,41 \%)$. Mittaamatta jääneet ajat on laskettu mukaan esitettyihin lukuihin kyseisten perusaikojen suuruisina virheinä.

Mitattava aika vaikutti mittaustarkkuuteen. Perusajan lyhentyessä alle $10 \mathrm{cmin}$ kasvoi mittaamatta jääneiden aikojen osuus jyrkästi. Mitattavan ajan vaikutus suht. poikkeamaan oli myös erittäin selvä. Sopiva mitattavan ajan alaraja olisi koehenkilöillä ollut n. $15 \ldots 20$ cmin.

Tutkimuspaikan ulkoiset olosuhteet vaikuttivat mittaustarkkuuteen. Olosuhteiden edesauttaessa vaihtumahetken havaitsemista tai rajoittaessa muta kuin tutkimuskohteesta tulevaa informaatiota parani mittaustarkkuus.

Eri laitteilla saavutettavassa mittaustarkkuudessa oli selviä eroja. Printterin mittaustarkkuus jäi keskimääräistä heikommaksi. Erityisesti puuttuvien aikojen osuus oli sillä korkea, mikä viittaa laitteessa esiintyneisiin mahdollisesti yksilöllisiin käyttö- ja toimintahäiriöihin. Osoitinnäytöllä varustettujen kellojen mittaustarkkuus parani selvästi, jos niissä osoitin voitiin pysäyttää mittaushetkellä ja lukea tulos vasta sen jälkeen. Tällaisilla kelloilla mittaustarkkuus muodostui samaksi kuin toiminnaltaan vastaavalla digitalkellolla. Suoran mittauksen yhteydessä tapahtunut tulosten lävistäminen reikäkorteille aiheutti huomattavasti enemmän virheitä kuin normaali kirjaaminen kynällä paperille.

Eri koehenkilöt käyttivät eri ajanmittauslaitteita eri tavalla. Tulosten mukaan näyttää siltä, että laitteen käyttötavan yksinkertaistuessa ja virheellisten käyttömahdollisuuksien vähentyessä pienenee mittaajan vaikutus laitteelle saavutettavaan tarkkuuteen.

Myös henkilöaineistossa eri koehenkilöiden välillä oli selviä eroja mittaustarkkuudessa. Keskimääräinen abs. poikkeama jäi yhteensä 14 koehenkilöllä $(7,9 \%)$ alle 0.5 cmin $/$ mittaus. Eri ikäisten koehenkilöiden mittaustarkkuudessa oli eroja. Koska eri ikäluokkiin liittyy aineistossa myös muita kuin pelkkiä ikäeroja, mm. eroja harjaantuneisuudessa, tarkkuusvaihtelun ei voi katsoa johtuneen pelkästään ikäeroista. Koehenkilöiden peruskoulutustason 
lisääntyessä parani mittaustarkkuus selvästi. Ammattikoulutuksen suhteen ei sen sijaan ollut havaittavissa vastaavaa suuntausta.

Työntutkimuskurssien soveltuvuustestien tuloksista ns. älykkyystestin pistemäärä oli selvimmin riippuvuussuhteessa mittaustarkkuuteen. Sen sijaan ajanmittausvaiheen tarkkuuden ja ns. mekaanis-teknisen lahjakkuuden välillä ei ollut selvää riippuvuussuhdetta.

Ajanmittausvaiheessa mittaustarkkuuteen vaikuttaneet eri tekijät voidaan tiivistää viiteen eri ryhmään seuraavasti:

1. Ajanmittauslaite ja -menetelmä

2. Vaihtumahetken havaitsemismahdollisuus

3. Mitattavan ajan pituus

4. Mittaajan harjaantuneisuus

5. Inhimilliset tekijät mittaushetkellä

Lineaarisella regressiomallilla ei pystytty selittämään edes tyydyttävästi mittaustarkkuutta, vaan mallien selitysasteet jäivät erittäin alhaisiksi. Tulosten perusteella näyttää ilmeiseltä, ettei tietyn henkilön soveltuvuutta aikatutkijaksi voi määrittää luotettavasti pelkästäăn yksinkertaisesti selvitettävissä olevilla, hänen ominaisuuksiaan kuvaavilla muuttujilla. Tämä on tehtävissä huomattavasti luotettavammin esim. tutkimuksessa käytettyä simulointia vastaavalla työkokeella. 